\title{
EFFECTIVE TAX STRATEGIES: IT'S NOT JUST MINIMIZATION
}

\author{
A Dissertation \\ by \\ STEVANIE ALYSSE SCHNEIDER NEUMAN \\ Submitted to the Office of Graduate and Professional Studies of \\ Texas A\&M University \\ in partial fulfillment of the requirements for the degree of \\ DOCTOR OF PHILOSOPHY
}

$\begin{array}{ll}\text { Chair of Committee, } & \text { Thomas Omer } \\ \text { Co-Chair of Committee, } & \text { Sean McGuire } \\ \text { Committee Members, } & \text { Anwer Ahmed } \\ & \text { Dudley Poston } \\ \text { Head of Department, } & \text { James Benjamin }\end{array}$

August 2014

Major Subject: Accounting

Copyright 2014 Stevanie Alysse Schneider Neuman 


\begin{abstract}
This study examines managerial incentives and practices associated with firms' tax strategy choices, as well as the relative importance of these factors in determining the primary focus of firms' tax strategies. Understanding the determinants of firms' tax strategy choices is important because the Scholes-Wolfson framework argues that the goal of effective tax planning is to maximize after-tax returns. Therefore, identifying managerial incentives and practices that influence tax strategy choice provides insight into how firms encourage tax planning to improve firm value. Using seemingly unrelated bivariate probit regression, I investigate firms' tendencies to focus on one of two tax strategies: a sustainable tax strategy, which strives to achieve a consistent tax outcome over time, and a minimization tax strategy, which seeks to achieve the lowest possible tax outcome.

Controlling for the interdependence of tax strategies, I find that firms are more likely to emphasize a sustainable tax strategy when the CEO's wealth is more sensitive to changes in the firm's stock price and less likely to emphasize sustainability when the firm receives more information from its directors' connections. In contrast, a firm is more likely to concentrate on a minimization tax strategy when the CEO's wealth is more sensitive to changes in stock return volatility, the firm hires a tax expert audit firm for tax services, or the firm receives more information from its directors' connections. Finally, I find that managerial incentives are the most important factors for the choice of tax strategy, followed by the practices of obtaining expert tax advice and information from directors' connections. This study contributes to the literature by providing evidence that managerial incentives and practices are associated with firms' tax strategy choices, a decision that precedes observed tax outcomes and cannot
\end{abstract}


necessarily be inferred from tax outcomes alone. Furthermore, a firm's tax outcome depends upon its tax strategy, and thus, by identifying managerial incentives and practices that affect tax strategy choice, this study provides an additional explanation for the variation in tax outcomes observed across firms, as well as develops expectations regarding the tax strategy that firms are likely to employ. 


\section{DEDICATION}

To my husband. Without his love and support I would have lost my way. 


\section{ACKNOWLEDGEMENTS}

I am grateful for the comments and insights of my dissertation committee: Tom Omer (Chair), Sean McGuire, Anwer Ahmed, and Dudley Poston. I appreciate helpful comments from Andy Bauer, Anne Beatty, Michael Donohoe, Mike Ettredge, Jere Francis, Jeff Hoopes, Tom Kubick, Pete Lisowsky, Nate Newton, Ed Outslay, Sonja Rego, Darren Roulstone, and Dan Wangerin and workshop participants at Indiana University, Michigan State University, The Ohio State University, Texas A\&M University, the University of Kansas, the University of Illinois at Urbana-Champaign, the University of Missouri, and the 2013 Accounting Ph.D. Rookie

Recruiting and Research Camp. I also thank Bree Josefy for her suggestions and Frances Tice for sharing the director connectedness data. 


\section{TABLE OF CONTENTS}

Page

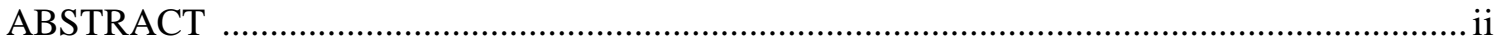

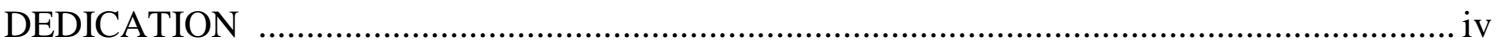

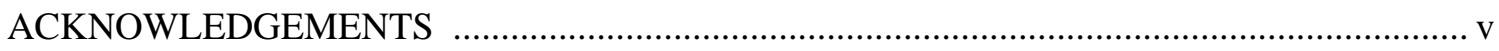

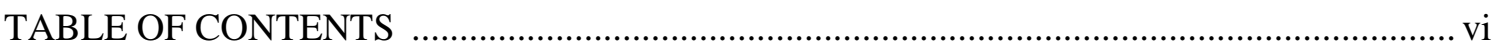

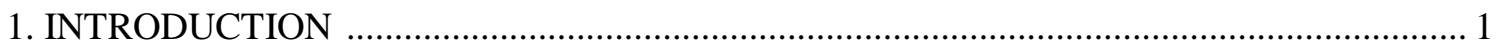

2. BACKGROUND ON TAX STRATEGY AND ITS DIMENSIONS .................................... 12

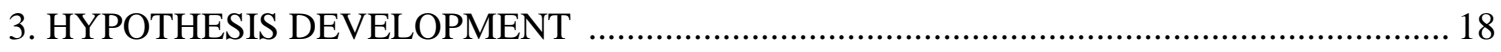

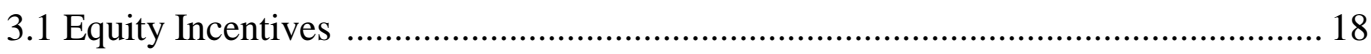

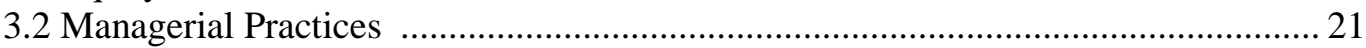

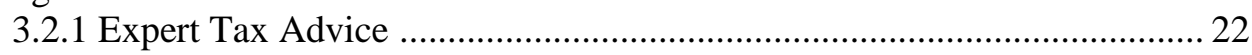

3.2.2 Information Transfer among Directors ............................................... 24

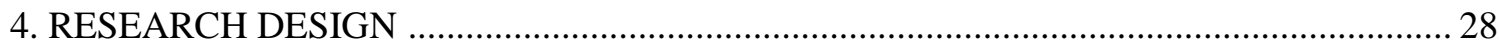

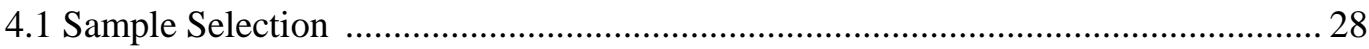

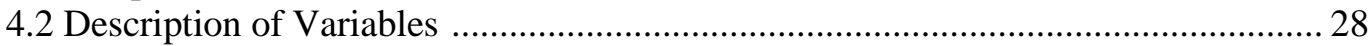

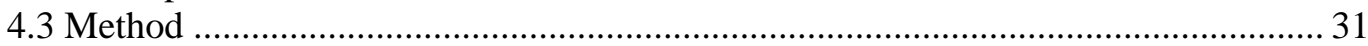

4.3.1 Hypothesis One - Equity Incentives ................................................ 34

4.3.2 Hypothesis Two - Expert Tax Advice ................................................... 35

4.3.3 Hypothesis Three - Information Transfer among Directors .................... 37

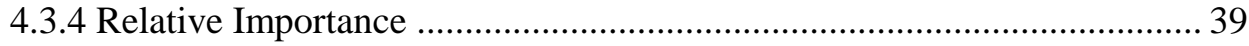

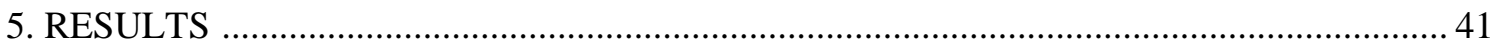

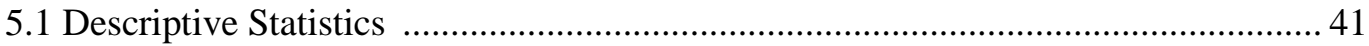

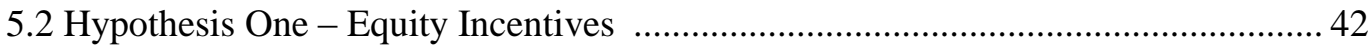

5.3 Hypothesis Two - Expert Tax Advice ...................................................................... 44

5.4 Hypothesis Three - Information Transfer among Directors .................................... 46

5.5 Relative Importance ....................................................................................... 47

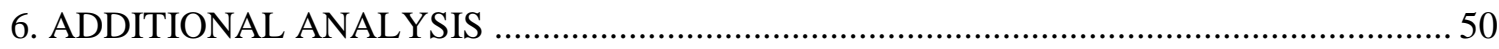

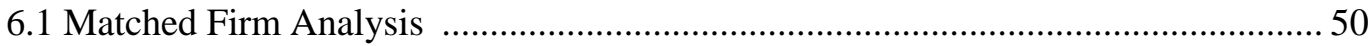

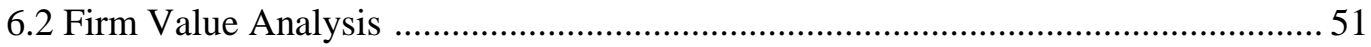

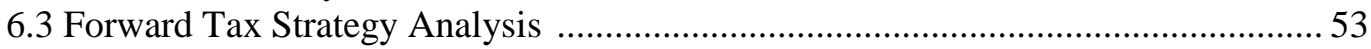


6.4 Tax Strategy Classification using GAAP ETR ....................................................... 55

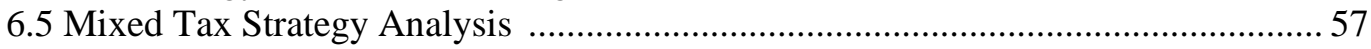

6.6 Both Tax Strategy Analysis ................................................................................ 59

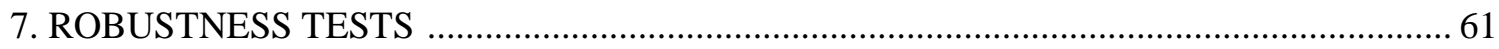

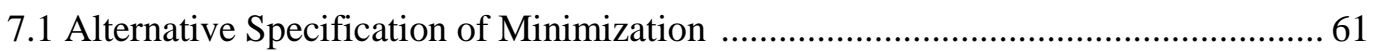

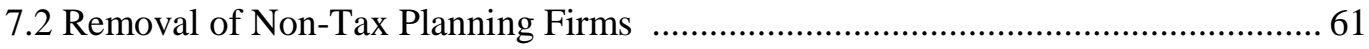

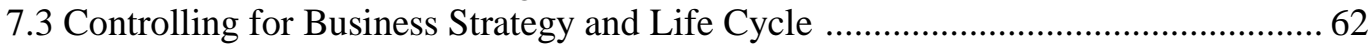

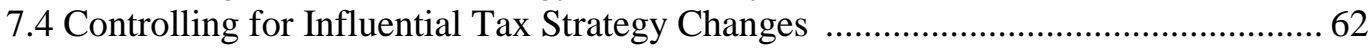

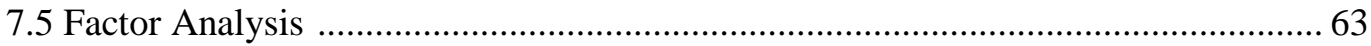

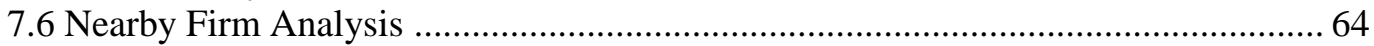

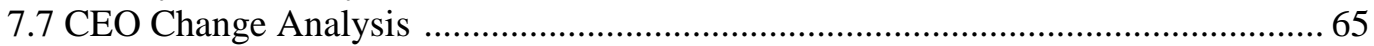

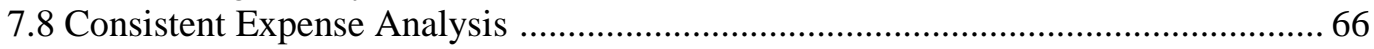

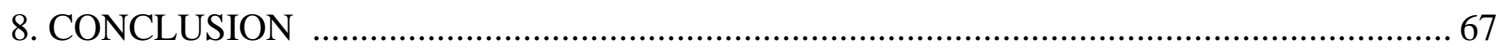

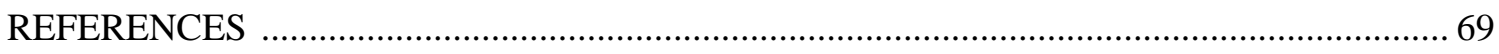

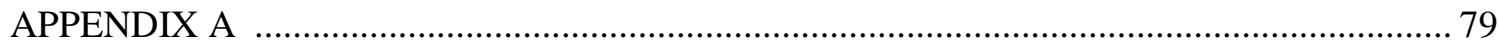

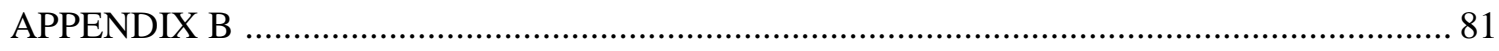

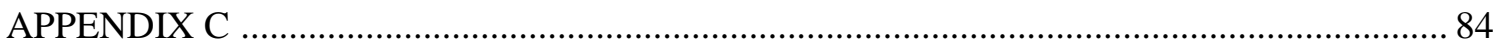




\section{INTRODUCTION}

Recent empirical and anecdotal evidence suggests that a firm's tax strategy consists of at least two recognizable dimensions, sustainability and minimization (e.g., Deloitte LLP 2013; KPMG LLP 2007; McGuire et al. 2013). The dimension of a firm's tax strategy that focuses on sustainability strives to achieve a consistent tax outcome over time (i.e., a narrow range of effective tax rates (ETRs)), with less regard for that tax outcome's level (McGuire et al. 2013; Neuman et al. 2013). In contrast, the dimension of a firm's tax strategy that focuses on minimization seeks to reduce the firm's tax burden and achieve the lowest possible tax outcome (i.e., a low ETR). Despite the presence of multiple dimensions, prior research generally focuses on firms' tax avoidance with the implicit assumption that all firms emphasize the level of tax avoidance (i.e., minimization) (Shackelford and Shevlin 2001; Hanlon and Heitzman 2010); however, only a subset of firms are able to achieve low ETRs (Dyreng et al. 2008), implying that there are alternative approaches to maximizing after-tax returns. I extend this line of research by investigating why firms choose to concentrate more on sustainability or minimization. Specifically, I examine the managerial incentives and practices associated with firms' tax strategy choices, as well as the relative importance of these factors in determining the primary focus of firms' tax strategies. ${ }^{1}$

Understanding the determinants of firms' tax strategy choices is important because the Scholes-Wolfson framework argues that the goal of effective tax planning, which is the underpinning of tax strategy, is to maximize after-tax returns and firm value (Scholes et al. 2009). Therefore, by identifying managerial incentives and practices that influence tax strategy

\footnotetext{
${ }^{1}$ Consistent with the prior research, I acknowledge that sustainability and minimization are two dimensions of the overarching tax strategy. However, similar to the strategy literature, for ease of exposition, I will also refer to them as sustainable or minimization tax strategies.
} 
choice, this study provides insight into how firms encourage tax planning to improve firm value. The management literature defines a strategy as an observable pattern in decision-making (Hambrick 1981, 1983; Miles and Snow 1978; Mintzberg 1978), and prior research finds that strategies are inherently multi-faceted because firms can achieve the strategy's objective using different approaches (Hambrick 1983; Miller 1986, 1987; March 1991; Porter 2004; Shapiro 1989; Zahra and Covin 1993). For example, when developing the typologies of business strategy, Miles and Snow (1978) suggest that firms can follow one of two primary approaches for competing in a product market - an innovation strategy or an efficiency strategy. Firms can successfully compete using either business strategy, but the two models of production differ; thus, firms choose a business strategy that complements their competitive advantage. Similarly, firms must balance tax and other organizational considerations to maximize firm value (Dyreng et al. 2008; Scholes et al. 2009). Therefore, like other firm strategies, there are different, yet equally effective, approaches to tax strategy.

Prior research identifies two different dimensions of a firm's tax strategy that help maximize after-tax returns: improving the consistency of the tax outcome and reducing cash taxes paid. The literature demonstrates the importance of non-tax considerations for tax planning (e.g., Scholes et al. 2009) and indicates that firms attempt to avoid tax-related surprises (Schmidt 2006; Armstrong et al. 2012; TEI 2005) and balance tax avoidance and financial reporting costs (Mills 1998; Mills and Newberry 2001), implying that consistent or sustainable tax outcomes are preferable in some situations. Practitioners also market tax planning activities with sustainable outcomes because such tax strategies increase long-term firm value (Deloitte LLP 2013; KPMG LLP 2007; PwC 2008). However, there is also ample evidence consistent with the notion that some firms emphasize the lowest tax outcome (minimization). For example, prior research suggests that managers are often incentivized to obtain low ETRs (Phillips 2003; 
Robinson et al. 2010; Armstrong et al. 2012), and anecdotal and empirical evidence indicates that some firms are able to achieve low ETRs (e.g., Dyreng et al. 2008; Schumpeter 2012; Kocieniewski 2011; Duhigg and Kocieniewski 2012).

Unique costs and benefits accompany each tax strategy. Firms emphasizing sustainability experience low year-to-year variability in tax outcomes (Deloitte LLP 2013; KPMG LLP 2007; PwC 2008), improving firm value through lower earnings and cash flow volatility (e.g., Barth et al. 1999; Myers et al. 2007; Rountree et al. 2008) and reducing the possibility of unfavorable financial reporting effects (Mills 1998; Scholes et al. 2009).

Furthermore, sustainable tax strategies reduce firms' exposure to negative press related to tax planning issues (Deloitte LLP 2013), which can result in significant reputation costs (Hanlon and Slemrod 2009). However, by investing in tax planning that produces more predictable tax outcomes, these firms could be paying more tax than required (Deloitte LLP 2013; McGuire et al. 2013; TEI 2005). Firms focusing on minimization benefit from the increased cash flow of lower explicit tax burdens (Hanlon and Heitzman 2010; Maydew 1996; Mills 1998; Phillips 2003), which provides additional funds for investing (Armstrong et al. 2012; Ayers et al. 2009; Schumpeter 2012). However, low ETRs also increase the risk of audit by revenue authorities, possibly resulting in penalties and fines for disallowed tax avoidance (Ayers et al. 2009; Cloyd 1995; Cloyd et al. 1996; Mills 1998; Mills and Sansing 2000; Schumpeter 2012), and tax minimization can create significant reputation costs (Hanlon and Slemrod 2009).

Although both tax strategies have costs and benefits, it is important to note that either strategy can be value-maximizing. Prior literature indicates that commonly-observed typologies within strategies are capable of allowing firms to earn acceptable returns (Porter 2004), which implies that, if properly implemented, either tax strategy (i.e., emphasizing sustainability or minimization) can successfully maximize after-tax firm value. In other words, in an absolute 
sense, one tax strategy is not better than the other. However, at the individual level, firms' unique situations ultimately determine the most appropriate strategic approach because certain circumstances are better suited for one strategy than another (Porter 2004; Miles et al. 1978; Hambrick 1983). ${ }^{2}$ Therefore, in this study, I am interested in investigating firms' tax strategy decisions and improving our understanding of why firms choose to emphasize a sustainable or minimization tax strategy.

The purpose of this study is to examine the determinants of firms' tax strategy choices. The objective of managerial incentives and practices is to shape managers' values and facilitate decision-making that is consistent with shareholders' interests (Jensen and Meckling 1976). Mills et al. (1998) assert that investments in tax planning, and thus tax strategy, will vary with managements' practices and incentives. Therefore, controlling for investments in tax planning, the choice of tax strategy likely depends upon the incentives and practices in place at the firm. Accordingly, I examine the association between the choice of tax strategy and three managerial incentives and practices: providing equity incentives, obtaining expert tax advice, and transferring information through directorships.

The compensation contract informs the manager about shareholders' objectives and the manner in which he/she should approach maximizing firm value (Diamond and Verrecchia 1982; Holmstrom 1979; Jensen and Meckling 1976). Shareholders value tax planning because tax strategy contributes to profitability (Scholes et al. 2009); thus, managerial incentives should align managers' and shareholders' interests with respect to tax strategy decisions (Hanlon and Heitzman 2010), and are therefore, potentially important for tax strategy choice. Prior research supports this argument and finds that compensation and equity incentives are associated with

\footnotetext{
${ }^{2}$ This idea is analogous to the business strategy literature which indicates that both innovation and efficiency are value-creating means of production, but that firms will choose to focus on the business strategy that aligns with their competitive advantages.
} 
firms' tax avoidance (Armstrong et al. 2012; Desai and Dharmapala 2006; Phillips 2003; Rego and Wilson 2012), consistent with shareholders providing incentives to encourage tax planning (Hanlon and Heitzman 2010).

Equity incentives encourage different types of behavior. Increasing the sensitivity of the manager's wealth to changes in the stock price (delta) encourages the manager to increase the stock price. Prior research has shown that firms with more persistent earnings exhibit higher stock prices (e.g., Barth et al. 1999; Kasnik and McNichols 2002; Myers et al. 2007) and firms with more sustainable tax strategies exhibit more persistent earnings (McGuire et al. 2013), which suggests that, if managers are incentivized to increase the stock price, they may be more likely to emphasize sustainability. On the other hand, increasing the sensitivity of the managers' wealth to stock return volatility (vega) encourages the manager to make relatively more risky investments. A minimization tax strategy will likely require the manager to undertake aggressive tax avoidance activities or uncertain tax positions (Hanlon et al. 2007; Rego and Wilson 2012), which suggests that, if managers are incentivized to invest in relatively more risky projects, they may be more likely to emphasize minimization. Therefore, I hypothesize that a firm is more likely to implement a sustainable (minimization) tax strategy as its managers' wealth becomes more sensitive to changes in the stock price (stock return volatility).

In addition to managerial incentives, I also consider two managerial practices, obtaining expert tax advice and transferring information through directorships, which facilitate the spread of tax planning ideas and represent sources of information that may be helpful for implementing a tax strategy. It is costly and difficult for individual firms or managers to develop or identify tax avoidance activities, but external sources of tax planning information could be an efficient way to ascertain tax planning opportunities, and thus, access to these sources could influence firms' tax strategy choices. 
Expert tax advice represents a valuable source of tax planning information because accounting firms invest in training and tax planning knowledge to serve their clients' needs (Ferguson et al. 2003; Solomon et al. 1999). Thus, tax experts are likely able to offer information about the most recent tax planning innovations, as well as industry-specific tax avoidance activities, which can improve their clients' abilities to emphasize minimization (Deloitte Development LLC 2013; Ernst \& Young 2013; PricewaterhouseCoopers 2013). On the other hand, practitioners specifically market tax planning activities with sustainable tax outcomes (Deloitte LLP 2013; KPMG LLP 2007; PwC 2008); thus, expert tax advice could also be associated with the choice of a sustainable tax strategy. Therefore, depending on the relative amounts of information tax experts provide about the two tax strategies, professional advice from tax experts could be associated with a higher likelihood of choosing either tax strategy.

Firms can also benefit from the tax information transferred via connections among members of boards of directors. The relationships among directors form an extensive network across which information, including corporate policies, is shared, and prior research demonstrates that firms are more likely to implement a policy or strategy found at another firm when connections among directors exist (e.g., Gulati and Westphal 1999; Bizjak et al. 2009). ${ }^{3}$ Because information pertaining to many corporate policies reaches firms via directors' interactions, tax planning information is likely to travel in a similar manner. Consistent with this notion, Brown (2011) documents that tax shelter use spreads through board interlocks.

Furthermore, tax directors meet regularly with the board, particularly the audit committee, to discuss tax planning (ATA 2014), indicating that directors have direct communication with the individuals responsible for implementing tax strategy. Thus, anecdotal and empirical evidence

\footnotetext{
${ }^{3}$ Prior research provides evidence consistent with both value-increasing (e.g., Gulati and Westphal 1999; Haunschild 1993; Palmer et al. 1986; Palmer et al. 1989) and value-decreasing (e.g., Bizjak et al. 2009; Dooley 1969; Pennings 1980) corporate policies traveling between firms through links among directors.
} 
suggests that directors discuss tax planning opportunities and that information transferred through directors could be influential for the choice of tax strategy. Depending on their connections, directors will have access to different types of tax planning information (i.e., predictable (innovative) tax planning opportunities which facilitate sustainability (minimization)). Therefore, depending on the relative amounts of information directors provide about tax strategies, information transferred through directors' connections could be associated with a higher likelihood of choosing either tax strategy.

To investigate whether managerial incentives and practices are associated with firms' tax strategy choices, I examine the association between equity incentives, expert tax advice, and information transferred through directorships and the decision to emphasize a sustainable or minimization tax strategy. Following prior research in accounting and management (e.g., Bentley et al. 2012; Hambrick 1981, 1983; Higgins et al. 2014; Ittner et al. 1997), I focus on two distinct tax strategies, sustainability and minimization, and examine firms that have made an explicit tax strategy choice. I classify a firm as adopting a sustainable tax strategy if its coefficient of variation of cash ETRs, measured from $t$ to $t$-4 (McGuire et al. 2013; Neuman et al. 2013), is in the lowest quintile for the year and as emphasizing a minimization tax strategy if its three-year cash ETR, measured from $t$ to $t$-2 (Dyreng et al. 2008), is less than or equal to 20 percent. ${ }^{4,5}$ I measure equity incentives using delta and vega (Core and Guay 1999; Guay 1999), expert tax advice using audit firm tax expertise (McGuire et al. 2012), and information

\footnotetext{
${ }^{4}$ My results remain unchanged if I use the five-year cash ETR to define a minimization tax strategy.

${ }^{5}$ My approach of using observable tax outcomes measured over a period of time to infer firms' unobservable tax strategies is consistent with the methodology of empirical analyses of business strategy (e.g., Bentley et al. 2012; Higgins et al. 2014) in which firm characteristics derived from financial statement data are used to operationalize unobservable business strategy.
} 
transferred through directorships using director connectedness (Newman 2010; Omer et al. 2012, 2014). ${ }^{6}$

Using a sample of firm-year observations at the intersection of the Compustat, CRSP, Execucomp, Audit Analytics, and Risk Metrics databases from 2000-2010, I investigate firms' tendencies to focus on one of two tax strategies using seemingly unrelated bivariate probit regression. I use this methodology because the two dimensions of tax strategy are not independent (i.e., the decision to concentrate on sustainability is related to the decision to concentrate on minimization); thus, the probability of making a particular decision must be estimated assuming a joint distribution for both tax strategies (Woolridge 2010, 595-6).

Seemingly unrelated bivariate probit regression models both tax strategy choices together, controlling for the simultaneous determination of the decision to focus on one dimension of tax strategy and forego emphasizing the other.

Controlling for both the interdependence of these tax strategies and firm characteristics that could affect both tax planning resources and opportunities, my results indicate that, when the CEO's wealth is more sensitive to changes in stock price (i.e., larger delta), the firm is more likely to concentrate on sustainability, suggesting that managers align the firm's tax strategy with their incentives to increase the stock price. However, firms that incentivize their CEOs to make riskier decisions (i.e., larger vega) are more likely to emphasize minimization, consistent with these managers being rewarded for volatility which results from investing in activities with less predictable outcomes. With respect to expert tax advice, I find that firms that hire a tax expert audit firm for tax services are more likely to focus on minimization, consistent with these firms utilizing tax experts' knowledge of the latest tax planning opportunities to reduce their tax

\footnotetext{
${ }^{6}$ To measure information transfer among directors comprehensively, I use social network analysis and a vector of four centrality measures for firms' directors following the methodology of Newman (2010), rather than using board interlocks.
} 
burdens. Finally, I find that firms that receive substantial information from their directors' connections are less likely to focus on a sustainable tax strategy and more likely to emphasize a minimization tax strategy, which suggests that directors share more information about tax minimization opportunities than activities that produce consistent tax outcomes.

To examine the relative importance of managerial incentives and practices in determining the primary focus of firms' tax strategies, I include proxies for equity incentives, expert tax advice, and information transferred through directorships in the analysis simultaneously. My results are comparable to those of the individual tests (i.e., all variables of interest retain the same sign and level of significance). I compare the relative importance of the factors using fully standardized coefficients and find that the sensitivity of the CEO's wealth to changes in the stock price is more important than information transfer to the decision to emphasize sustainability. Firms that focus on minimization are influenced most by equity incentives (vega), followed by expert tax advice, and finally, information from directors' connections. My results suggest that, in general, equity incentives are not only associated with observed tax outcomes, as documented in the prior literature, but more importantly, represent the most important determinants of the tax strategy choice which produces the observed tax outcomes examined by prior research.

In addition to my main analysis, I conduct a number of additional tests. First, to more directly control for the influence of tax planning opportunities on firms' tax strategy choices, I replicate my results using a sample of sustainable and minimization tax strategy firms matched on size within industry and year and find that managerial incentives and practices continue to be significant determinants of firms' tax strategy choices. Second, consistent with the notion that either tax strategy can be value-maximizing, I find that firms that choose either a sustainable or a minimization tax strategy have significantly higher current and future market value of equity 
relative to other firms without an explicit, observable tax strategy. Because firms' tax strategy choices are relatively stationary over time, I also investigate the association between firms' future tax strategy choices and current period managerial incentives and practices. My inferences are consistent with my main analysis and suggest that current period incentives and practices influence the choice of tax strategy one, two, and four years in the future. Furthermore, when I re-estimate my regressions after defining tax strategy using GAAP ETRs, my results with respect to expert tax advice and information transfer are unchanged. However, although my inferences with respect to equity incentives are similar (i.e., the sign of the coefficients is in the same direction), my results are attenuated because the coefficients are no longer significant at conventional levels.

The focus of my study is the two distinct tax strategies, sustainability and minimization; however, I also examine two other sets of firms. First, I investigate firms that follow a mixed tax strategy (i.e., firms that do not emphasize either sustainability or minimization). Using a multinomial logistic regression, I find that the effect of managerial incentives and practices on the choice of a mixed tax strategy falls near the middle of the effect of these factors for the choice of a sustainable or minimization tax strategy, consistent with this tax strategy incorporating elements of both sustainability and minimization. In addition, I also examine the small sample of firms that emphasize both sustainability and minimization. Although based on a limited number of observations, my results suggest that, not only do these firms have the resources and capabilities to focus on both tax strategies, but they also employ the incentives and practices necessary to encourage managers to focus on both dimensions of tax strategy, a combination that seems to allow them to simultaneously emphasize sustainability and minimization. 
This study makes three contributions to the literature. First, I extend the literature that examines the determinants of corporate tax avoidance by investigating firms' choice of tax strategy, by providing evidence that managerial incentives and practices are associated with firms' tax strategy choices, and by examining the relative importance of these factors for the choice of tax strategy. This study improves our understanding of the determinants of tax strategy (e.g., firm characteristics, performance factors, and managerial incentives/practices), which is important because researchers know relatively little about what influences firms' tax strategy choices. Although the prior literature has investigated some of these characteristics and their association with tax avoidance and tax sheltering activities, it has not analyzed these incentives/practices in the context of how they influence the tax strategy choice, a decision that precedes observed tax outcomes and cannot necessarily be inferred from tax outcomes alone, nor has it considered sustainable and minimization tax strategies in conjunction with one another.

Second, despite prior literature's identification of numerous factors and firm characteristics that are associated with firms' tax avoidance, little of the variation in tax outcomes has been explained (Hanlon and Heitzman 2010; Shevlin 2007). A firm's tax outcome depends on its tax strategy, and thus, by classifying firms based on tax strategy and identifying managerial incentives and practices that affect tax strategy choice, this study provides an additional explanation for the variation in tax outcomes observed across firms, as well as develops expectations regarding the tax strategy that firms are likely to employ. Finally, by identifying managerial incentives and practices associated with the choice of tax strategy, this study provides insight into how firms encourage tax planning that improves firm value. 


\section{BACKGROUND ON TAX STRATEGY AND ITS DIMENSIONS}

Tax strategy can be defined as a pattern of decision-making and actions with respect to tax planning that maximizes after-tax returns and firm value (Scholes et al. 2009). By examining the variation in tax outcomes and the determinants and consequences of tax avoidance (see Hanlon and Heitzman (2010) for a review of the recent literature), prior research has sought to explain observed tax outcomes (e.g., ETRs, book-tax differences, the incidence of tax sheltering). In contrast, this study examines firms' tax decisions from a different perspective. The purpose of this study is to investigate the managerial incentives and practices associated with firms' tax strategy choices. The choice of tax strategy is a higher-level decision that precedes and primarily determines firms' observed tax outcomes; thus, this study extends prior research by examining the determinants of the underlying tax strategy.

Because the goal of any strategy can be achieved using a variety of approaches, all firm strategies have several dimensions (Hambrick 1983; Miller 1987; Porter 2004; Zahra and Covin 1993). For example, Miles and Snow (1978) suggest that firms tend to follow one of two primary approaches to business strategy - an innovation approach or an efficiency approach. Both methods allow firms to successfully compete in their product markets, but the two production models differ. Porter (2004) indicates that managers choose a strategy based upon the firm's situation and its strengths and weaknesses. Thus, any dimension of a strategy can be value-maximizing, but managers make trade-offs between the dimensions to implement the strategy that best suits the firm and its situation (Hambrick 1983; March 1991; Porter 2004).

The Scholes-Wolfson framework argues that, because of non-tax costs, effective tax planning is not always achieved by focusing solely on tax minimization (Scholes et al. 2009), and prior research supports this argument. Specifically, Dyreng et al. (2008) indicate that tax 
avoidance does not always improve market value because the reduction of explicit taxes may be accompanied by implicit taxes (i.e., non-tax costs), implying that there are considerations that could lead firms to focus on a tax objective other than minimization. Similarly, Robinson et al. (2010) acknowledge that lower ETRs do not always imply effective tax planning, and Phillips (2003) indicates that a low ETR represents tax savings, but does not necessarily indicate that after-tax returns have been maximized. Furthermore, although there are a number of firms that achieve substantial tax avoidance (e.g., Dyreng et al. 2008), many firms reduce their tax burdens by relatively small amounts. Collectively, the prior literature provides a strong basis for the conclusion that, similar to other firm strategies, there are multiple tax strategies that can successfully improve after-tax returns and firm value.

The strategy literature consistently classifies firms into typologies by identifying the most salient observable strategies. Although every strategy will not be represented by the classifications, they predict organizational behavior with reasonable accuracy (Miles et al. 1978). Consistent with this approach, I chose to focus on sustainability and minimization because these the most common dimensions of tax strategy, firms following either strategy are readily identifiable, and the two strategies are observable both empirically and in discussions offered in the practitioners' literature. An emphasis on a sustainable tax strategy is likely when firms use recurring tax planning techniques to achieve consistent tax outcomes over time. These firms are mindful of the variability of tax outcomes, but potentially have less regard for the tax outcome's level (McGuire et al. 2013; Neuman et al. 2013). Firms emphasizing sustainability will primarily pursue long-term tax avoidance activities with more predictable tax outcomes (e.g., cost recovery for purchases of capital equipment and unrepatriated earnings from foreign operations in stable countries with well-documented tax laws). In contrast, an emphasis on a minimization tax strategy is likely when firms focus on achieving the lowest possible tax 
outcome using a combination of recurring and one-time tax planning opportunities (Mills et al. 1998). These firms are more concerned about the level of the current year's tax outcome than about being consistent with the surrounding years' outcomes. Firms emphasizing minimization will pursue a much wider range of tax avoidance activities - long-term and short-term tax avoidance activities with both predictable and less certain tax outcomes (e.g., cost recovery on purchases of capital equipment, unrepatriated earnings from a wide variety of foreign operations, research and experimentation tax credits, and transfer pricing).

Empirical and anecdotal evidence is consistent with the existence of both sustainable and minimization tax strategies. With respect to sustainability, Mills (1998) and Mills and Newberry (2001) provide evidence indicating that firms must balance tax avoidance and financial reporting costs. Furthermore, prior research and survey evidence indicate that firms prefer to avoid taxrelated surprises (Schmidt 2006; Armstrong et al. 2012; TEI 2005), and concurrent research finds that some firms are able to sustain their tax outcomes over the long-term (e.g., McGuire et al. 2013; Neuman et al. 2013). Finally, practitioners advertise tax planning activities with sustainable outcomes because they suggest that such tax strategies increase long-term value (Strategic Capital Partners, LLC 2012; Deloitte LLP 2013; KPMG LLP 2007; PwC 2008). However, prior research also confirms the existence of minimization tax strategies by suggesting that managers are often incentivized to focus on reducing tax outcomes (Phillips 2003; Robinson et al. 2010; Armstrong et al. 2012) because it increases income and, in some instances, encourages behavior that mitigates other incentive problems (Scholes et al. 2009). Ayers et al. (2009) also indicate that many firms benefit from deferring taxes. Finally, there is substantial evidence that some firms are able to achieve low ETRs (e.g., Dyreng et al. 2008; Schumpeter 2012; Kocieniewski 2011; Duhigg and Kocieniewski 2012), implying that tax minimization may be optimal for some firms. 
There are costs and benefits associated with both sustainability and minimization. Firms focusing on sustainability experience low year-to-year variability in tax outcomes (Deloitte LLP 2013; KPMG LLP 2007; PwC 2008) and are less likely to have tax-related earnings surprises (Armstrong et al. 2012; Schmidt 2006; TEI 2005) and/or unfavorable financial reporting effects (Mills 1998; Scholes et al. 2009). These firms also have less volatile and more persistent earnings (McGuire et al. 2013), which improves firm value due to their predictable, consistent earnings' strings (e.g., Barth et al. 1999; DeAngelo et al. 1996; Kasznik and McNichols 2002; Mills and Newberry 2001; Myers et al. 2007). Sustainable tax strategies may also be preferred by some firms because Graham et al. (2005) find that 97 percent of CFO survey respondents desire smooth earnings, which investors view as less risky. Fewer earnings surprises and unfavorable financial reporting effects and higher earnings persistence have all been linked to improved firm values (see Dechow et al. 2010 for a review of the literature), but practitioners' most advertised reason for adopting a sustainable tax strategy is reputation costs (Deloitte LLP 2013; KPMG LLP 2007; PwC 2008). These tax strategies reduce firms' exposure to negative press related to tax planning issues (Deloitte LLP 2013), which can be a significant concern for firms (Graham et al. 2013; Hanlon and Slemrod 2009). However, emphasizing a sustainable tax strategy is not without costs. Firms with sustainable tax strategies could, by investing in tax planning that produces more predictable outcomes, be paying more tax than legally owed (Deloitte LLP 2013; McGuire et al. 2013; TEI 2005), reducing cash available for investment. ${ }^{7}$ Furthermore, once this strategy has been established, these firms may also face greater pressure to maintain consistent outcomes because sudden volatility could be viewed as a signal of poor management (KPMG LLP 2007).

\footnotetext{
${ }^{7}$ On average, firms following sustainable tax strategies in my sample pay higher taxes than firms following minimization tax strategies (average three-year cash ETR of 28.7 percent versus 11 percent).
} 
Firms emphasizing minimization benefit from the increased income and cash flow associated with a lower explicit tax burden (Hanlon and Heitzman 2010; Maydew 1996; Mills 1998; Phillips 2003). Rather than being paid out as tax expense, cash taxes saved represents additional cash flow that can be invested in positive net present value projects (Armstrong et al. 2012; Ayers et al. 2009; Schumpeter 2012), increasing firm value. These firms will be less concerned about the risk or variability of any tax activity's expected outcome, as well as the length of time the tax avoidance opportunity will exist; thus, they draw upon a wider range of tax planning activities. However, there are several potential costs of the minimization tax strategy. Low ETRs increase the risk of audit by revenue authorities, which potentially results in penalties and fines for disallowed tax avoidance that could negate the original tax benefit (Ayers et al. 2009; Cloyd 1995; Cloyd et al. 1996; Mills 1998; Mills and Sansing 2000; Schumpeter 2012). Scholes et al. (2009) also warn that a minimization tax strategy can become an ineffective tax strategy if non-tax costs are not fully considered (Deloitte LLP 2013; Mills and Newberry 2001; Phillips 2003). Finally, tax minimization can create significant reputation costs. The idea of being a good corporate citizen, particularly with respect to taxes, became more salient during the latest recessionary period (Deloitte LLP 2013; Hanlon and Slemrod 2009), leading firms to seek to avoid negative attention, and detrimental consequences, related to their tax strategies (Graham et al. 2013). For example, Cook et al. (2014) show that tax avoidance perceived as aggressive is associated with higher costs of capital, and Starbucks found the backlash to its legitimate tax avoidance in the U.K. so harmful to sales that it announced that the company will forgo claiming an allowed deduction and pay \$30.8 million in taxes in 2013 and 2014 (BBC 2013). Because each tax strategy has costs and benefits, managers must consider these trade-offs, in conjunction with their firm's unique circumstances, to choose the appropriate value-maximizing tax strategy. 
I expect firms to emphasize one tax strategy because the strategy literature provides evidence that it is difficult, if not impossible, for a firm to simultaneously focus on two dimensions of a strategy (March 1991). Firms' stakeholders will implement policies and managers will take actions that depend on the dimension of a strategy that is being pursued (e.g., Miles and Snow 1978). The set of viable policies and actions for each dimension of a strategy are unlikely to have substantial overlap, which generally prohibits emphasizing multiple dimensions simultaneously. Therefore, based on the prior literature; the different costs and benefits of each tax strategy; and the different tax planning actions associated with each dimension of tax strategy, I expect firms to emphasize either a sustainable or minimization tax strategy and to seldom have the capability to emphasize both dimensions of tax strategy. ${ }^{8}$

\footnotetext{
${ }^{8}$ Within my sample, there are some firms that are able to emphasize both sustainability and minimization; however, consistent with the prior literature, it is very small sample (187 observations). In section 6, I conduct additional analyses using this subsample to provide insights into how these firms might be able to focus on both dimensions of tax strategy simultaneously.
} 


\section{HYPOTHESIS DEVELOPMENT}

Because shareholders' and managers' interests often do not align, managerial incentives and practices are used to ensure that the stewards of the firm make decisions in a manner that is consistent with stakeholders' interests (Jensen and Meckling 1976). The choice of tax strategy is likely influenced by these factors because their purpose is to affect decision-making. Prior research supports this notion. Dyreng et al. (2008) argue that management's actions determine a firm's tax strategy, and Mills et al. (1998) assert that investments in tax planning, and thus tax strategy, will vary due to management's incentives and practices. Therefore, in this study, I examine three managerial incentives and practices -providing equity incentives to executives, obtaining expert tax advice, and transferring information through directorships - and their association with firms' tax strategy choices. ${ }^{9}$

\subsection{Equity Incentives}

According to principal-agent theory, shareholders structure compensation contracts and employ incentives to link managers' wealth to firm performance, thereby aligning the agent's interests with the principal's (Diamond and Verrecchia 1982; Holmstrom 1979; Jensen and Meckling 1976). Core and Guay (1999) find that, in general, firms provide equity incentives in a manner that matches the predictions of optimal contracting, suggesting that incentives are given to target agency conflicts and influence decision-making. Firms manage and rely primarily on two types of equity incentives - the sensitivity of the manager's wealth to stock price or firm performance (commonly referred to as delta) and the sensitivity of the manager's wealth to stock

\footnotetext{
${ }^{9}$ While firm characteristics (e.g., business structure, assets, resources) will undoubtedly influence available tax planning opportunities, I focus on equity incentives, expert tax advice, and information transfer because this study's objective is to explore factors beyond a firm's innate characteristics that affect tax strategy choice. I include a vector of control variables to account for the impact of firm characteristics on tax strategy choice.
} 
return volatility or variability in firm performance (commonly referred to as vega). When a manager's wealth depends on firm performance, the manager is incentivized to increase the firm's stock price (Guay 1999). However, by also compensating the manager for stock return volatility (vega), shareholders can encourage decision-making that promotes engaging in all positive net present value projects, even more risky investments and policies (e.g., Chava and Purnanandam 2010; Coles et al. 2006; Guay 1999).

Managerial incentives represent an important factor for the choice of tax strategy because the compensation contract informs the manager about the amount of effort that should be devoted to tax planning (Hanlon and Heitzman 2010; Slemrod 2004) and the type of tax planning (i.e., strategy) shareholders desire (Armstrong et al. 2012; Phillips 2003; Rego and Wilson 2012). ${ }^{10}$ Because tax strategy contributes to firms' profitability (Scholes et al. 2009), shareholders value tax planning; therefore, managerial incentives will align the interests of managers and shareholders with respect to tax strategy decisions (Hanlon and Heitzman 2010). Prior research supports this assertion and concludes that equity incentives and compensation are associated with firms' tax avoidance (Armstrong et al. 2012; Desai and Dharmapala 2006; Phillips 2003; Rego and Wilson 2012). In addition, Robinson et al. (2010) find that a firm's GAAP ETR depends on the performance evaluation metric used for the tax department, and Powers et al. (2013) find that CEOs with cash bonuses tied to after-tax performance targets report lower GAAP ETRs than CEOs with pre-tax performance targets, indicating that specific details of managers' compensation contracts are associated with tax avoidance. Because equity

\footnotetext{
${ }^{10}$ I am not suggesting that the compensation contract explicitly states which tax strategy to choose or the portion of the executive's time that should be devoted to tax planning. However, the contract will provide information about the activities shareholders value most, as well as the executive's evaluation metrics, some of which are likely after-tax values (e.g., Phillips 2003; Robinson et al. 2010). Thus, the compensation contract will influence the manager's tax strategy choice as he aligns his decision-making with his incentives to maximize his wealth.
} 
incentives are designed to impact decision-making, I expect that managers' wealth sensitivity to firm performance or stock return volatility is associated with tax strategy choice.

The objective of increasing the sensitivity of the manager's wealth to changes in the stock price (delta) is to encourage the manager to improve firm value by raising the stock price. There are a number of aspects of firm performance or earnings quality linked to higher stock prices, but one aspect, earnings persistence, has been shown to be associated with sustainability. In general, firms with more persistent or predictable earnings exhibit higher stock prices (e.g., Barth et al. 1999; DeAngelo et al. 1996; Kasznik and McNichols 2002; Myers et al. 2007), and firms with more sustainable tax strategies exhibit more persistent earnings (McGuire et al. 2013), which suggests this type of tax strategy is related to higher firm performance. Furthermore, riskaverse managers will invest in projects with more predictable outcomes (Smith and Stulz 1985); therefore, if managers are incentivized to increase the stock price, they may be more likely to emphasize sustainability. Thus, I expect the sensitivity of the manager's wealth to changes in the stock price (delta) to increase the likelihood that a firm engages in a sustainable tax strategy.

Compensating the manager for improving firm performance reduces some agency conflicts; however, risk-averse managers will avoid investing in risky, but valuable projects (Smith and Stulz 1985). Thus, shareholders may choose to supplement these incentives with equity incentives that increase the sensitivity of the manager's wealth to stock return volatility (vega) to encourage broader investment preferences (e.g., Guay 1999). As compensation for stock return volatility increases, the manager will be more inclined to balance investment in projects with more predictable outcomes and cash flows with investment in relatively more risky opportunities.

I expect a shift in incentive structure that encourages risk-taking to increase the likelihood that a firm emphasizes a minimization tax strategy rather than a sustainable tax 
strategy for several reasons. First, firms focusing on sustainability are less likely to engage in risky activities (Deloitte LLP 2013); however, a minimization tax strategy will likely require the manager to undertake risky tax avoidance activities - activities that are either aggressive (Desai and Dharmapala 2006; Hanlon et al. 2007; Rego and Wilson 2012) or less likely to be upheld by the taxing authority - which lead to more volatile tax outcomes, and ultimately, stock returns. In addition, Guenther et al. (2013) find that firms with more volatile cash ETRs have higher future stock return volatility, suggesting that stock return volatility may be negatively associated with sustainability and that managers of firms with sustainable tax strategies are unlikely to be rewarded for volatile stock returns. However, Rego and Wilson (2012) find that the sensitivity of the manager's wealth to stock return volatility is associated with tax avoidance, suggesting a positive relation between incentives to engage in riskier activities and minimization. Thus, I expect the sensitivity of the manager's wealth to stock return volatility (vega) to increase the likelihood that a firm engages in a minimization tax strategy.

Collectively, I expect equity incentives to influence the likelihood of choosing a particular tax strategy and state the following hypothesis:

H1: A firm will be more likely to implement a sustainable tax strategy (minimization tax strategy) as its managers' wealth becomes more sensitive to changes in stock price (stock return volatility).

\subsection{Managerial Practices}

Managerial incentives are an important decision-making factor because they are used to align shareholders' and managers' interests and encourage certain types of decisions, and thus are likely associated with tax strategy choice. However, managerial practices may also be influential for the choice of tax strategy because these practices represent sources of information that may be helpful for implementing a strategy. In this study, I specifically examine two 
potential sources of tax planning information - expert tax advice and information transferred among directors. I discuss each managerial practice below.

\subsubsection{Expert Tax Advice}

One source of tax planning information is the professional advice of tax experts. Organizational behaviorists define professional advice as a recommendation that "could help decision-makers make better decisions and avoid mistakes, help them think about new information, [and] help them organize their thoughts" (Bonaccio and Dalal 2006, 143). Because of the complex nature of tax planning, managers may consult tax experts for advice prior to implementing a tax strategy. Theory and prior research suggest that decision-makers solicit advice to improve the likelihood of making an optimal decision, particularly when they do not have prior experience with the decision or activities it involves (Bonaccio and Dalal 2006; Harvey and Fischer 1997; Yaniv 2004a, b). Managers will be keenly familiar with the firm's business, but may not have extensive tax planning experience. However, tax experts possess superior knowledge of industry-specific tax avoidance techniques, as well as general tax planning opportunities (McGuire et al. 2012), and are likely to offer the most recent innovations in tax planning, which can improve their clients' abilities to develop effective strategies to generate tax savings (Deloitte Development LLC 2013; Ernst \& Young 2013; PwC 2013).

Tax fees comprise a substantial percentage of accounting firm revenue (Zeff 2003; Public Accounting Report 2008), and tax planning is a large portion of the services that tax practitioners provide. Therefore, expert tax advice could facilitate the client's choice of an effective tax strategy because accounting firms invest in training and knowledge to develop tax plans for their clients (Solomon et al. 1999; Ferguson et al. 2003). Consistent with this notion, studies have shown that employing professional advice improves decision accuracy (Gardner and Berry 1995; Sniezek et al. 2004; Yaniv 2004a) and that high quality advice from solicited, 
expert sources is more likely to be implemented than other types of advice (Jungerman and Fischer 2005; Jungermann 1999; Yaniv and Kleinberger 2000; Yaniv and Milyavsy 2007; Gino 2008; Gibbons et al. 2003). Therefore, because of the potential benefits of their specialized knowledge, I expect that obtaining professional advice from tax experts is a managerial practice associated with the choice of tax strategy.

Ex ante, obtaining expert tax advice could be associated with the choice of either a sustainable or a minimization tax strategy. The managers of a firm with a sustainable tax strategy take advantage of more predictable tax avoidance opportunities (Deloitte LLP 2013) and have the ability to control and forecast operations and income (McGuire et al. 2013; Neuman et al. 2013), which allows them to engage in long-run tax planning (Schmidt 2006). Although these firms are less interested in innovative tax avoidance activities, they will seek information about recurring tax avoidance activities that have been consistently upheld by the taxing authority. It is conceivable that tax experts are a source of this type of information because practitioners market tax strategies with sustainable outcomes (Strategic Capital Partners, LLC 2012; Deloitte LLP 2013; KPMG LLP 2007; PwC 2008). Thus, if the information that tax experts provide improves firms' abilities to implement a tax strategy that generates consistent tax outcomes through recurring, long-term tax avoidance activities, then I expect that hiring a tax expert audit firm for tax services is associated with a higher likelihood of adopting a sustainable tax strategy.

In contrast to firms emphasizing sustainability, to employ a minimization tax strategy, managers must engage in all feasible tax planning opportunities, which increases the value of information on the latest tax law changes, new tax planning techniques, and industry-specific tax avoidance activities. Tax experts are key sources of this type of information (Deloitte Development LLC 2013; Ernst \& Young 2013; PwC 2013). Because it is costly and difficult for 
managers to individually obtain the information necessary to minimize taxes (Bonner et al. 1992; Deloitte Development LLC 2013; Ernst \& Young 2013; McGuire et al. 2012; SD Mayer \& Associates LLP 2013), firms implementing a minimization tax strategy may find the specialized knowledge of tax experts beneficial. Furthermore, McGuire et al. (2012) find that firms that hire their tax expert audit firm for tax services avoid more taxes on average, indicating that experts reduce tax outcomes and implying that expert tax advice could facilitate minimization. Thus, hiring a tax expert audit firm for tax services may also be associated with a higher likelihood of choosing a minimization tax strategy.

Accounting firms advertise a number of tax planning opportunities, and tax experts can provide information that would contribute to a firm's ability to engage in either a sustainable or minimization tax strategy. Thus, depending on the relative amounts of information tax experts provide about the two tax strategies, it is possible that obtaining expert tax advice increases the likelihood of choosing either tax strategy. Therefore, I state the following hypothesis:

H2: Hiring a tax expert audit firm for tax services will influence a firm's choice of tax strategy.

\subsubsection{Information Transfer among Directors}

A second source of tax planning information is information transferred among firms' directors. Relationships among firms' directors form an extensive network across which information that may contribute to firm behavior or decision-making can be shared. Indeed, social network theory emphasizes the importance of relationships among individuals for observed behavior, both at an individual and an entity level (Borgatti and Halgin 2011; Phelps et al. 2012). The interactions among firms' directors may influence strategy choices because Borgatti and Halgin (2011) suggest that the primary function of a network is to transfer information and that members' behavior is often a function of network placement because of its impact on the amount and timeliness of information received. To model the interactions among 
individuals, social network analysis uses networks to map the connections of individuals or entities within a particular system (Haythornthwaite 1996; Krause et al. 2007; Newman 2010). ${ }^{11}$ Specifically, the technique of social network analysis has been used to examine the availability and transfer of resources, ideas, innovations, and information across members of a network (e.g., Haythornthwaite 1996, 2009; Scott 1991; Wasserman and Faust 1994; Wellman and Berkowitz 1988), including networks of directors (e.g., Andres and Lehmann 2010; Barnea and Guedj 2009; Davis et al. 2003; Horton et al. 2012; Larcker et al. 2013; Omer et al. 2012, 2014).

Prior research suggests that information transferred among directors could affect firms' tax strategy choices. For example, there is evidence consistent with both value-increasing (e.g., Gulati and Westphal 1999; Haunschild 1993; Palmer et al. 1986; Palmer et al. 1989) and valuedecreasing (e.g., Bizjak et al. 2009; Dooley 1969; Pennings 1980) corporate policies traveling across firms through directors' connections. These studies demonstrate that firms are more likely to implement a policy or strategy found at another firm when there are connections among the directors. Because information related to a wide range of corporate policies and strategies flows from one firm to the next via directors' interactions, tax planning information is likely to travel in a similar manner. Consistent with this notion, prior research finds that tax shelters spread across firms via interlocking directors (Brown 2011), firms with board interlocks tend to pay a similar level of tax (Brown and Drake 2013), and firms avoid more taxes when the audit committee has higher levels of financial expertise (Robinson et al. 2012). Furthermore, tax directors meet regularly with the board, particularly the audit committee, to discuss tax planning (ATA 2014), indicating that directors have direct communication with the individuals responsible for implementing tax strategy. Thus, anecdotal and empirical evidence suggests that

\footnotetext{
11 There are many possible definitions of a link between individuals within a network - professional relationships, communication, information flow, etc. (Newman 2010); however, in this study, I focus on information transfer.
} 
directors share tax planning information which may influence tax strategy choice. Finally, effective tax planning cannot be accomplished without adequate knowledge of available tax planning opportunities and, given the significant cost of identifying tax planning activities (e.g., Deloitte Development LLC 2013; Ernst \& Young 2013; SD Mayer \& Associates LLP 2013), firms may consult each other for tax planning information to improve efficiency. While it is unlikely that directors themselves have the technical tax expertise to explain a tax planning technique or tax strategy, they can share tax planning information by introducing their peers to the individual or entity responsible for their tax strategy. Thus, based upon the prior literature, I expect information transferred through directors' connections to be associated with the choice of tax strategy.

Ex ante, information transferred through directors' connections could be associated with the choice of either a sustainable or a minimization tax strategy. To achieve consistent tax outcomes, the managers of firms with sustainable tax strategies invest in recurring tax avoidance activities that are more likely to be sustained upon audit (Deloitte LLP 2013). Implementing a long-term tax strategy with recurring tax avoidance activities is complex; however, if directors receive information identifying tax planning opportunities previously upheld by the taxing authority, then tax planning information available through directors' connections to other firms may be useful for maintaining a sustainable tax strategy. Directors could be a source of this type of information because a number of firms exhibit more sustainable tax outcomes (McGuire et al. 2013), suggesting that some directors have knowledge of these tax strategies, and many accounting firms, which directors may have done business with, market sustainable tax strategies (Deloitte LLP 2013; KPMG LLP 2007; PwC 2008). Thus, I expect that information transferred through directors' connections increases the likelihood that a firm adopts a sustainable tax strategy. 
In contrast, firms focusing on minimization are expected to employ all available tax avoidance mechanisms, which would require information about new tax planning opportunities or the tax avoidance activities being used by their peers and competitors. Directors are likely sources of information related to tax minimization because Brown (2011) shows that board interlocks are associated with specific transactions (i.e., tax shelters) whose goal is to minimize taxes. Therefore, prior research indicates that directors' connections, and the information obtained through those connections, may be an important determinant of focusing on a minimization tax strategy. Therefore, I expect information transferred through directors' connections could also increase the likelihood that a firm chooses a minimization tax strategy.

Directors have access to different types of tax planning information through their connections to other firms. This information is likely a combination of innovative tax planning opportunities and more predictable tax avoidance activities. Thus, depending on the relative amounts of these two types of information, it is possible that information transferred through directors' connections increases the likelihood of choosing either tax strategy. Therefore, I hypothesize that:

H3: The information transferred to a firm through its directors' connections will influence a firm's choice of tax strategy. 


\section{RESEARCH DESIGN}

\subsection{Sample Selection}

To investigate my hypotheses, I obtain a sample of firm-year observations at the intersection of the Compstat, CRSP, Execucomp, Audit Analytics, and Risk Metrics databases from 2000-2010. Consistent with prior literature, all firms in the sample are incorporated in the U.S., have total assets greater than zero and positive pre-tax book income in the current year, and do not operate in the financial services or utilities sectors. ${ }^{12}$ In addition, I require that the observations have non-missing data for cash taxes paid and pre-tax book income for three of the five years necessary to calculate sustainability. Finally, to maintain a consistent sample, I exclude firm-year observations that lack the data necessary to calculate any of the variables used in the analysis - the tax strategy variables, variables of interest, or controls. My final sample consists of 4,668 firm-year observations (1,137 unique firms).

\subsection{Description of Variables}

Following prior research, I define a sustainable tax strategy as a tax strategy that achieves a consistent tax outcome over time (i.e., a narrow range of ETRs), regardless of the tax outcome's level (e.g., McGuire et al. 2013; Neuman et al. 2013), and a minimization tax strategy as a tax strategy that focuses on obtaining the lowest possible tax outcome (e.g., Dyreng et al. 2008; Scholes et al. 2009). Firms' tax strategies are defined in terms of a goal for long-term tax outcomes; thus, to isolate firms' tax strategies, I examine their behavior, and the resulting tax outcomes, over time. Specifically, I operationalize tax strategy using the distribution of observed tax characteristics and identify firms that consistently demonstrate tax behavior that is

\footnotetext{
${ }^{12}$ I remove financial services and utilities firms from the sample due to differences in their accounting requirements.
} 
representative of the two dimensions of tax strategy. My approach of using observable tax outcomes measured over a period of time to infer firms' unobservable tax strategies is consistent with the methodology of empirical analyses of business strategy (e.g., Bentley et al. 2012; Higgins et al. 2014) in which firm characteristics derived from financial statement data are used to operationalize unobservable business strategy.

I classify firms as following a sustainable tax strategy using the coefficient of variation of annual cash ETRs ( $\left.C V \_C E T R\right)$ measured over the five-year period, $t$ to $t-4$, following McGuire et al. (2013). CV_CETR is calculated as the standard deviation of annual cash ETRs scaled by the absolute value of the mean of annual cash ETRs and measures the variability in a firm's tax outcome level over the five-year period. Firms with low variability maintain a consistent range of cash ETRs over time; thus, I define a sustainable tax strategy using CV_CETR (McGuire et al. 2013). Specifically, I rank firms by year according to CV_CETR, and a firm is categorized as following a sustainable tax strategy if its coefficient of variation is in the lowest quintile for the year. ${ }^{13}$ Thus, SUSTAIN equals one if a firm's tax outcomes exhibit low variability over time, and zero otherwise. Coca-Cola, Conoco-Phillips, Kimberley-Clark, and United Parcel Service are examples of firms in my sample that focus on sustainability. I classify firms as following a minimization tax strategy using the cash ETR measured over the three-year period, $t$ to $t$-2, following Dyreng et al. (2008). ${ }^{14}$ The three-year cash ETR

\footnotetext{
${ }^{13}$ Because firms classified as following a sustainable tax strategy will vary with the underlying population, I define SUSTAIN using all available observations with data necessary to calculate CV_CETR. This method ensures that I am examining firms that have consistent tax outcomes relative to the larger population of firms.

${ }^{14}$ I measure minimization over a three-year period for two reasons. First, I use a three-year measure rather than an annual measure to control for the annual volatility of ETRs and measure the firm's tax strategy over time. Second, I use a three-year period rather than a five-year period because Dechow and Dichev (2002) argue that most firm operations, and the associated cash flows, complete their accounting cycle within a three-year period. I use a five-year period to estimate $C V \_C E T R$ to be consistent with prior literature that calculates coefficients of variation (e.g., Minton and Schrand 1999; Minton et al. 2002). My
} 
(CETR3) equals the three-year sum of cash taxes paid divided by the three-year sum of pre-tax book income less special items and measures the average tax outcome over the three-year period. Firms with low cash ETRs are able to achieve a relatively high level of tax avoidance over time; thus, I define a minimization tax strategy using CETR3 (Dyreng et al. 2008). Specifically, a firm is categorized as following a minimization tax strategy if its three-year cash ETR is less than or equal to 20 percent. ${ }^{15}$ Thus, MINIMIZE equals one if a firm reports low tax outcomes over time, and zero otherwise. Apple, Eli Lilly, International Paper, and PeopleSoft are several firms in my sample that emphasize minimization. Please see Appendix A for detailed examples of firms identified as following either a sustainable or minimization tax strategy. ${ }^{16}$

I measure tax strategies using cash ETRs for several reasons. First, firms' tax strategies will ultimately be reflected in the cash paid to taxing authorities. Hanlon et al. (2005) indicate that firms have more discretion over the calculation of financial statement income than taxable income; thus, while ETRs based upon financial statement income may suggest that a firm has adopted a particular tax strategy, the cash paid to taxing authorities is likely more representative of the tax strategy in place, as well as the firm's execution of that strategy. Second, GAAP ETRs and cash ETRs capture different aspects of tax planning. For example, GAAP ETRs are not affected by tax activities that defer taxes, but changes in the tax accruals (i.e., the valuation allowance or the tax reserve) will affect GAAP ETR. On the other hand, cash ETRs take into account tax activities that defer taxes and are unaffected by changes in tax accruals (Hanlon and Heitzman 2010). Therefore, because cash ETRs are a more comprehensive measure of tax

inferences are unchanged when I use the five-year cash ETR to identify firms that emphasize minimization (please see Section 7 for a discussion of this additional analysis).

${ }^{15}$ I define the minimization tax strategy as a CETR3 less than or equal to 20 percent because Dyreng et al. (2008) define low tax rate firms as those with a rate of 20 percent or less (p. 62).

${ }^{16}$ See Appendix B for detailed definitions of all variables used in this study. 
planning activities (i.e., temporary and permanent differences) that are not impacted by the judgment inherent in the tax accrual process, I operationalize firms' tax strategies using cash ETRs. ${ }^{17}$

\subsection{Method}

The two dimensions of tax strategy are not independent. Because a firm cannot simultaneously emphasize both tax strategies, but both tax strategies are potentially available to the firm, the decision to concentrate on sustainability cannot be separated from the decision to concentrate on minimization. ${ }^{18}$ Thus, the choice of tax strategy represents a situation in which the probabilities of choice directly affect one another and are endogenous (Mallar 1977). Therefore, the error terms of the models of these two choices are dependent upon one another, and the probability of adopting one tax strategy must be estimated assuming a joint distribution of both tax strategy choices (Woolridge 2010, 595-6). To control for the interdependence of this choice, I employ seemingly unrelated bivariate probit regression to identify which managerial incentives and practices are associated with a higher likelihood of emphasizing a sustainable or minimization tax strategy.

Seemingly unrelated bivariate probit regression is a simultaneous probability model, an analysis that models binary relationships whose probability of occurrence influences the probability of another event or decision (Mallar 1977). ${ }^{19}$ This model is analogous to a seemingly

\footnotetext{
${ }^{17}$ Cash ETRs are not perfect measures of firms' tax activities; for instance, they are affected by stock option expensing. Thus, I examine the sensitivity of my results to measuring tax strategy using GAAP ETRs. My inferences, presented in Section 6, are similar using this alternative classification.

18 The strategy literature suggests that it is difficult, if not impossible, for a firm to focus on two dimensions of a strategy at once (March 1991).

${ }^{19}$ I use this technique because neither Stata nor SAS have a program that permits estimating logistic regressions simultaneously. Furthermore, seemingly unrelated regression was developed for linear regression models and could produce inconsistent coefficient estimates when used for regressions with binary dependent variables.
} 
unrelated regression model, but the dependent variables are binary indicator variables rather than continuous variables (Cappellari and Jenkins 2003). Seemingly unrelated bivariate probit regression permits analyzing both tax strategies simultaneously, allows the inclusion of all observations rather than requiring that the sample be split based upon the dependent variable, and assumes a joint distribution of the two tax strategies. Thus, this methodology specifically controls for the simultaneous nature of the decision to focus on one tax strategy and forego emphasizing the alternative tax strategy, providing consistent, and efficient, coefficient estimates for the effect of the variables of interest on the choice of tax strategy.

To examine whether managerial incentives and practices influence the choice of tax strategy, I develop a model of firms' tax strategy choices. Specifically, for each managerial incentive or practice, I estimate the following systems of equations:

$$
\begin{aligned}
& \text { SUSTAIN }_{i t}=\alpha+\beta_{1} \text { INCENTIVES } / \text { PRACTICES }_{i t}+\beta_{2-7} \text { TAX PLANNING } i t \\
& +\beta_{8-10} \text { PERFORMANCE } E_{i t}+\beta_{11-12} \text { INVEST/REPORT } i t+\beta_{13} I M R_{i t} \\
& + \text { industry }+\varepsilon \\
& \text { MINIMIZE }_{i t}=\alpha+\beta_{1} \text { INCENTIVES/PRACTICES }_{i t}+\beta_{2-7} \text { TAX PLANNING }_{i t} \\
& +\beta_{8-10} \text { PERFORMANCE } E_{i t}+\beta_{11-12} I_{N V E S T / R E P O R T}+\beta_{13} I M R_{i t} \\
& + \text { industry }+\varepsilon \text {, }
\end{aligned}
$$

where SUSTAIN is an indicator variable equal to one if the firm focuses primarily on a sustainable tax strategy, and zero otherwise, and MINIMIZE is an indicator variable equal to one if the firm focuses primarily on a minimization tax strategy, and zero otherwise (both defined above). INCENTIVES/PRACTICES represents one of the four variables of interest: DELTA and VEGA, TAXEXPERT, and INFO TRANSFER, to be defined below. All variables are defined in Appendix B. 
I also include controls for firm characteristics, performance, and investing and reporting decisions that could potentially affect firms' tax strategy choices. ${ }^{20}$ First, I control for firm characteristics that impact investments in tax planning, TAX PLANNING (Mills et al. 1998). I proxy for firm size using the natural logarithm of sales (SIZE) and leverage using total long-term debt scaled by end-of-the-year total assets (LEVERAGE). I also control for property, plant, and equipment, measured net of depreciation and scaled by end-of-the-year total assets (PPE); foreign operations, using an indicator variable equal to one if the firm has foreign income and zero otherwise (FOR_OP); tax loss carryforwards, using an indicator variable equal to one if the firm reports a tax loss carryforward and zero otherwise (TLCF); and complexity, using the number of segments a company reports in a given year (SEGMENTS). These firm characteristics are important to tax strategy choice because they play a central role in determining firms' available tax planning opportunities (Mills et al. 1998).

I control for firm performance using three proxies - pre-tax earnings volatility, returnon-assets, and the book-to-market ratio. Firm performance will influence the choice of tax strategy for several reasons: a firm cannot owe taxes without earning a profit; resources for tax planning, income and cash flow, are derived from performance; and performance volatility potentially represents a non-tax cost. I measure a firm's pre-tax earnings volatility using the coefficient of variation of pre-tax book income $\left(C V \_P T B I\right)$, the standard deviation of annual pretax book income scaled by the absolute value of the mean of pre-tax book income over the fiveyear period, $t$-4 to $t$. In addition, I control for the firm's profitability using return-on-assets $(R O A)$ and the book-to-market ratio (BTM). I also include two measures of investing and

\footnotetext{
${ }^{20}$ To develop a parsimonious model of firms' tax strategy choices, I follow the procedure outlined by Hosmer and Lemeshow to determine a comprehensive, yet concise, set of control variables (Agresti 2007); however, I also examine the robustness of my results (discussed in Section 5) to the inclusion of additional control variables.
} 
reporting decisions because these policies and tax strategy choice are likely governed by the same guiding principles and investment policy can have significant tax consequences. I proxy for a firm's investment in innovative products using research and development expense $(R D)$ and control for a firm's financial reporting decisions using the signed value of performance-adjusted discretionary accruals (DISC_ACC) following Kothari et al. (2005). Further, when TAXEXPERT represents INCENTIVES/PRACTICES, I also include IMR, the inverse Mills ratio estimated from the selection model to be presented below, to control for the decision to purchase tax services from the audit firm. Finally, I include industry (two-digit SIC code) fixed effects to control for different environments and opportunities across industries.

\subsubsection{Hypothesis One - Equity Incentives}

To investigate whether managerial incentives are associated with firms' decisions to focus on a sustainable or minimization tax strategy, I simultaneously estimate models (1) and (2) using proxies for managers' equity incentives. My variables of interest are DELTA, the sensitivity of the CEO's wealth to changes in the stock price, and VEGA, the sensitivity of the CEO's wealth to stock return volatility. ${ }^{21}$ Following Core and Guay (1999), I calculate DELTA as the change in the CEO's wealth for a one percent change in the firm's stock price. I measure $V E G A$ as the change in the value of the CEO's stock option portfolio for a one percent change in stock return volatility (Guay 1999). A positive (negative) and significant coefficient on DELTA or VEGA is consistent with firms being more (less) likely to concentrate on either the sustainability or minimization dimension of tax strategy when managers have higher values of DELTA or VEGA. As suggested by Hypothesis 1 , I expect the coefficient on DELTA to be

${ }^{21}$ Following prior research (e.g., Chava and Purnanandam 2010; Coles et al. 2006; Rego and Wilson 2012), I simultaneously estimate the effect of DELTA and VEGA on the choice of tax strategy to control for both the overlapping and competing nature of these incentives within the executive's compensation contract. 
positive for firms focusing on sustainability because these firms promote firm value through consistent tax avoidance and the coefficient on VEGA to be positive for firms focusing on minimization because these firms engage in relatively more risky tax activities to achieve the lowest possible tax outcome.

\subsubsection{Hypothesis Two - Expert Tax Advice}

To examine whether seeking expert tax advice influences the tax strategy choice, I simultaneously estimate models (1) and (2) using audit firm tax expertise to proxy for the advice that managers obtain from tax experts. ${ }^{22}$ My variable of interest is TAXEXPERT, an indicator variable equal to one if the firm hires its audit firm for tax services and that audit firm possesses industry-specific tax expertise. Following McGuire et al. (2012), I define tax expertise as a tax service market share of 30 percent (25 percent) or more in years 2003 and later (2002 and earlier) within a Metropolitan Statistical Area (MSA) and industry, and zero otherwise. A positive (negative) and significant coefficient on TAXEXPERT is consistent with firms with access to expert tax advice being more (less) likely to concentrate on either the sustainability or minimization dimension of tax strategy. Hypothesis 2 suggests that the coefficient on TAXEXPERT will be positive for firms engaging in sustainable tax strategies because practitioners market tax planning with sustainable tax outcomes. I also expect the coefficient on TAXEXPERT to be positive for firms focusing on minimization because expert tax advice likely contains innovative tax planning insights that reduce firms' tax burdens.

The decision to hire the audit firm for tax services is not random, but rather determined by both observable and unobservable factors (Lassila et al. 2010; McGuire et al. 2012).

${ }^{22}$ A firm could also obtain professional advice from a tax expert that is not its auditor; however, publicly disclosed information on tax service provision is limited to firms that hire their auditor for tax services. Thus, due to current data availability, audit firm tax expertise is the best publicly available proxy for expert tax advice. 
Therefore, my analysis of the effect of expert tax advice on firms' tax strategy choices is potentially subject to selection bias because the factors that influence firms' decisions to hire the audit firm for tax services may also affect the association between expert tax advice and tax strategy choice. Consistent with prior research in accounting (e.g., Badertscher et al. 2009; McGuire et al. 2012; Omer et al. 2006; Tucker 2007), I employ the Heckman (1979) two-stage approach to control for potential selection bias. This two-stage procedure requires the estimation of a selection model which is used to construct an inverse Mills ratio that is included as a control variable in the main analysis.

Specifically, following McGuire et al. (2012), I estimate a probit regression that approximates the likelihood that a client hires its audit firm for tax services using the following model:

$$
\begin{aligned}
& \text { TAXSERVICE }_{i t}=\alpha+\beta_{1} \text { TENURE }_{i t}+\beta_{2} \text { INSTOWN }_{i t-1}+\beta_{3} \text { MERGER }_{i t}+\beta_{4} \text { AUDIND }_{i t} \\
& +\beta_{5} \text { LNAUDITFEES }_{i t}+\beta_{6} \text { OPPORTUNITY } i t+\beta_{7} \text { SIZE }_{i t}+\beta_{8} \text { DISC_ACC }_{i t} \\
& +\beta_{9} T L C F_{i t}+\beta_{10} \Delta T L C F_{i t}+\beta_{11} E Q I N C_{i t}+\beta_{12} F_{O R} O P_{i t}+\beta_{13} R D_{i t} \\
& +\beta_{14} \text { LEVERAGE }_{i t}+\beta_{15} \text { BTM }_{i t}+\beta_{16} P P E_{i t}+\beta_{17} R O A_{i t}+\beta_{18} C_{A S H} \\
& +\beta_{19} D E P_{i t}+\beta_{20} \text { BIG }_{i t}+\beta_{21} \text { SECTIER }_{i t}+\text { industry }+ \text { year }+\varepsilon \text {, }
\end{aligned}
$$

where all variables are defined in Appendix B. I calculate the inverse Mills ratio, IMR, using the coefficient estimates from model (3) and include IMR as a control variable in my secondstage regressions (i.e., models (1) and (2)/(4) and (5)). The inverse Mills ratio corrects for selection bias by controlling for observable and unobservable factors that influence firms' decisions to hire the auditor for tax services and that also potentially affect the association between expert tax advice and the choice of tax strategy (Heckman 1979). 


\subsubsection{Hypothesis Three - Information Transfer among Directors}

Finally, I examine whether information transferred through directors' connections influences the decision to focus on a sustainable or minimization tax strategy by simultaneously estimating models (1) and (2) using INFO TRANSFER as the variable of interest. I proxy for access to and transfer of information from other firms using directors' connectivity, a measure of a director's ability to obtain relevant information from other directors both within and outside of their firm's industry. INFO TRANSFER is a vector of four director centrality (connectivity) proxies measured using the factor score from a principal components factor analysis. In social network analysis, measures of centrality are used to identify the importance of connections within the network and to study interactions and information transfer among individuals (Bonacich 1987; Freeman 1979; Newman 2010).

The four centrality proxies that I use are NUM_CONNECTIONS, CONTROL, SPEED, and CONNECTION_STRENGTH. NUM_CONNECTIONS is calculated as the number of unique connections a director has with other directors in the network and proxies for access to information; directors with more connections have better access to information. CONTROL is calculated as the number of paths between two directors in the network, $a$ and $b$, that pass through director $i$ divided by the total number of paths between directors $a$ and $b$ and represents the control that director $i$ has over the flow of information from one area of the network to another. Directors with higher values of CONTROL are located on more paths between other directors in the network, and thus, control the flow of information.

The third proxy, SPEED, is measured as the inverse of the sum of the shortest distances of the paths between the director and other directors in the network and captures the speed at which a director receives information within a network. Directors with higher SPEED values receive information more quickly than directors with lower SPEED values. Finally, 
CONNECTION_STRENGTH is the number of unique connections a director has with other directors, where each of these connections is weighted based upon how well-connected those directors are within the network. Thus, CONNECTION_STRENGTH measures the centrality of a director within a network by assuming that certain connections provide more access to information than others; therefore, connections to other highly-connected directors are more valuable and directors with these connections receive a higher score. ${ }^{23}$

Each measure is first calculated at the director level and then aggregated up to the board; thus, I examine the impact of information transfer to the board as a whole on the likelihood of emphasizing either a sustainable or minimization tax strategy. ${ }^{24}$ In the principal components factor analysis, all four variables load on a single factor with an eigenvalue of 2.78 , and the proportion of the variance explained by the factor is approximately 70 percent. ${ }^{25}$ To examine Hypothesis 3, I am interested in the sign and significance of the coefficient on INFO TRANSFER. A positive (negative) and significant coefficient on INFO TRANSFER suggests that firms are more (less) likely to focus on either the sustainability or minimization dimension of tax strategy when directors have greater access to tax planning information from other firms' directors. I expect the coefficient on INFO TRANSFER to be positive for firms focusing on sustainability if directors share tax planning information that facilitates achieving consistent tax outcomes. Hypothesis 3 also posits that the coefficient on INFO TRANSFER will be positive for

\footnotetext{
${ }^{23}$ Within the social network analysis literature, NUM_CONNECTIONS is known as degree, CONTROL is referred to as betweeness centrality, SPEED is an individual's closeness centrality, and CONNECTION_STRENGTH is known as eigenvector centrality (Newman 2010). I have used alternative names for ease of exposition and interpretability, but my calculations of these variables are consistent with this literature.

${ }^{24}$ I only include observations connected to the largest component of the network in my sample. This component comprises approximately 83 percent of all directors with data necessary to calculate the centrality measures.

25 The factor loadings of NUM_CONNECTIONS,CONTROL,SPEED, and CONNECTION_STRENGTH are $0.95,0.86,0.87$, and 0.61 , respectively.
} 
firms focusing on minimization because directors are likely to share information about new tax avoidance opportunities.

\subsubsection{Relative Importance}

These managerial incentives and practices are unlikely to be equally important in determining the primary focus of firms' tax strategies. To investigate the relative importance of these factors for tax strategy choice, I simultaneously include my proxies for equity incentives, expert tax advice, and information transferred through directorships in the analysis. Specifically, I estimate the following system of equations:

$$
\begin{aligned}
& \operatorname{SUSTAIN}_{i t}=\alpha+\beta_{1} \text { DELTA }_{i t}+\beta_{2} \text { VEGA }_{i t}+\beta_{3} \text { TAXEXPERT } i t+\beta_{4} \text { INFO TRANSFER }_{i t} \\
& +\beta_{5-10} \text { TAX PLANNING } i t+\beta_{11-13} \text { PERFORMANCE } E_{i t} \\
& +\beta_{14-15} I N V E S T / R E P O R T_{i t}+\beta_{16} I M R_{i t}+\text { industry }+\varepsilon \\
& \text { MINIMIZE }_{i t}=\alpha+\beta_{1} \text { DELTA }_{i t}+\beta_{2} V_{E G A_{i t}}+\beta_{3} \text { TAXEXPERT } i t+\beta_{4} \text { INFO TRANSFER }_{i t} \\
& +\beta_{5-10} \text { TAX PLANNING } i t+\beta_{11-13} \text { PERFORMANCE } E_{i t} \\
& +\beta_{14-15} I N V E S T / R E P O R T_{i t}+\beta_{16} I M R_{i t}+\text { industry }+\varepsilon \text {, }
\end{aligned}
$$

where all variables have been previously defined. To determine which managerial incentives and practices are most important for firms' tax strategy choices, I compare the standardized coefficients for the four variables of interest, $\beta_{1}$ through $\beta_{4}$, for each tax strategy model. I do not make predictions regarding the relative importance of the managerial incentives and practices for the choice of tax strategy because it is unclear ex ante which of these factors will be the most important determinants of each tax strategy.

I use contemporaneous values of managerial incentives and practices to examine the determinants of firms' tax strategy choices for several reasons. First, prior research suggests that nonrecurring tax avoidance activities are a common method of tax reduction with firms seeking new opportunities each year (e.g., Mills et al. 1998), and because these activities change each 
year, engaging in nonrecurring tax avoidance requires current information. Furthermore, advice and information are only valuable when relevant. While some information or advice may be applicable for years, timeliness tends to affect relevance, particularly in a rapidly changing environment. Thus, given the continuous search for new tax planning ideas and the changing tax environment, the current year's information and advice will be important for tax strategy choice. Finally, because managers' equity incentives accumulate over time, and firms rebalance managers' incentives annually to reflect current objectives, decision-making in the current period, including tax strategy choice, will be a function of this year's incentives. ${ }^{26}$

\footnotetext{
${ }^{26} \mathrm{My}$ inferences remain unchanged if I use estimates of managerial incentives and practices from the prior year.
} 


\section{RESULTS}

\subsection{Descriptive Statistics}

I present all tables referenced in the manuscript in Appendix C. Table 1 reports descriptive statistics for my sample. Table 1, Panel A provides descriptive statistics for the tax strategy measures, the proxies for managerial incentives and practices, and the controls for investments in tax planning, firm performance, and investing and reporting choices for the full sample. ${ }^{27}$ Panels B, C, and D of Table 1 present descriptive statistics for the two tax strategy subsamples, as well as descriptive statistics for firms in the sample that are not classified as engaging in either sustainable or minimization tax strategies (i.e., mixed tax strategies). ${ }^{28}$ Univariate tests of mean and median differences of firm characteristics (untabulated) for firms with sustainable and minimization tax strategies indicate that these two subsamples are significantly different. Relative to firms with minimization tax strategies, firms that employ sustainable tax strategies are larger and more segmented, but less levered and less likely to report a tax loss carryforward (all $p<=0.01$ ). Firms focusing on sustainability also have lower earnings volatility and book-to-market ratios and invest less in research and development, but earn a higher return-on-assets than firms emphasizing tax minimization (all $p<0.01$ ). However,

${ }^{27}$ To ensure that my operationalizations of sustainability and minimization are capable of distinguishing between firms with different tax behavior, I examine the average range of annual cash ETRs (high - low) over the period $t-2$ to $t$ for firms in each tax strategy subsample. If I am identifying firms with different tax strategies, I would expect the average range of cash ETRs to be different for the two groups. I find that, on average, firms that focus on minimization have a wider range of annual cash ETRs than firms that emphasize sustainability ( 0.169 versus 0.091$)$. These results indicate that firms identified as following a sustainable tax strategy have lower variation in their tax outcomes over time and that my proxies are measuring two distinct tax strategies.

${ }^{28}$ Although firms can (and do occasionally) change their tax strategies, a firm's choice of tax strategy is relatively stationary over time. Within my sample, 33 (39) percent of firms are classified as following a sustainable (minimization) tax strategy for 100 percent of their firm-year observations. In addition, 64 (75) percent of firms are classified as following a sustainable (minimization) tax strategy for 50 percent of their firm-year observations. 
these firms exhibit similar investments in assets $(P P E)$, an equal likelihood of operating in a foreign jurisdiction, and a similar level of discretionary accruals. In addition, an untabulated analysis of the composition of the sample reveals that tax strategies are not concentrated within particular industries; I find that each tax strategy is present in all industries, where industry is defined by two-digit SIC codes.

Table 2 presents univariate correlations. ${ }^{29}$ Consistent with my definitions of tax strategy, I find that $C V_{-} C E T R$ (CETR3) is negatively associated with SUSTAIN (MINIMIZE). In addition, all four proxies of managerial incentives and practices are positively associated with SUSTAIN, while VEGA is positively associated with MINIMIZE. With the exception of the correlation between TAXEXPERT and VEGA, the variables of interest are positively associated with one another, indicating that they may be used jointly to promote a desired tax strategy. ${ }^{30}$ Furthermore, the incentives and practices and tax strategy variables are correlated with many of the control variables, indicating that a multivariate analysis is appropriate to control for the effect of these characteristics on the choice of tax strategy.

\subsection{Hypothesis One - Equity Incentives}

Table 3 presents the results of simultaneously estimating models (1) and (2) to examine the effect of managerial incentives on the likelihood that the firm emphasizes a sustainable or minimization tax strategy. Simultaneous estimation of the two models is appropriate because the likelihood ratio test of independence between the two models indicates that these two tax

\footnotetext{
${ }^{29}$ All coefficients discussed here (and in bold in Table 2) are significant at a minimum of the five percent level.

${ }^{30}$ I further examine the association between DELTA and VEGA by investigating the correlation of their quintile rankings. My untabulated results indicate that, in general, firms with higher values of VEGA also have higher values of DELTA, which is consistent with the need to incentivize focusing on value in addition to risk. Furthermore, there are zero instances of firms with VEGA in the top quintile and DELTA in the lowest quintile, suggesting that, if a firm incentivizes risk-taking, it must do so in a manner that also encourages value maximization.
} 
strategy choices are not independent $(p<0.01){ }^{31}$ I find a positive and significant coefficient on DELTA $(p<0.01)$ in column $(1)$, indicating that firms with CEOs whose wealth is more sensitive to changes in the stock price are more likely to focus on sustainability. The average marginal effect in column (3) indicates that a $\$ 1,000,000$ increase in the CEO's wealth increases the probability that the firm chooses a sustainable tax strategy by $0.009 .{ }^{32}$ In column (2), the positive and significant coefficient on VEGA $(p<0.01)$ suggests that managerial incentives that increase the sensitivity of the CEO's wealth to stock return volatility are associated with a higher likelihood that the firm emphasizes minimization. ${ }^{33}$ The average marginal effects reported in columns (3) and (4) indicate that a $\$ 1,000,000$ increase in the value of the CEO's stock option portfolio increases (decreases) the probability that a firm focuses on minimization (sustainability) by $0.097(0.053) .{ }^{34}$

Collectively, my results in Table 3 support Hypothesis 1 and suggest that managers make decisions in a manner consistent with the incentives they are provided through their compensation contracts. In other words, their tax strategy choices reflect their equity incentives predictably. For example, firms are more likely to focus on sustainability when managers are

${ }^{31}$ This methodology also produces an estimate of the correlation among the error terms of the two models, which indicates that these models are significantly, negatively correlated $(p<0.01)$, consistent with the decision to focus on one dimension of tax strategy reducing the likelihood that the firm focuses on the other dimension of tax strategy.

${ }^{32}$ The average total compensation for S\&P 500 CEOs was $\$ 12.3$ million in 2012, an increase of 8 percent over the previous year (AFL-CIO 2013; Popelka 2013), which corresponds to an increase of approximately $\$ 1,000,000$.

${ }^{33}$ My inferences are unchanged when I also control for the volatility of return-on-assets and prior tax avoidance (i.e., three-year cash ETR calculated over the period $t$-2 to $t-4$ ).

${ }^{34}$ I also examine whether equity incentives interact with either expert tax advice or information from directors' connections to influence the choice of tax strategy by including DELTA and VEGA and their interaction terms with TAXEXPERT and INFO TRANSFER, respectively, in the analysis of Hypotheses 2 and 3. I do not find a consistent interaction effect, and my inferences with respect to the main effects of all variables of interest remain the same. 
incentivized to focus on firm performance and the stock price, which reflects the fact that consistently achieving a tax outcome improves the firm's ability to meet earnings' targets, resulting in a stable and positively growing stock price. Similarly, firms are more likely to emphasize minimization when managers are incentivized to undertake projects that are riskier, but have positive expectations, consistent with managers engaging in tax planning activities that have a wider range of possible outcomes (i.e., new or previously scrutinized activities or activities that are subject to ambiguous interpretation of the tax law) which increase the volatility of net income and returns.

\subsection{Hypothesis Two - Expert Tax Advice}

Table 4 presents the results of estimating the decision to hire the audit firm for tax services (model 3). The selection model exhibits more than adequate discriminatory power with an area under the ROC curve of 0.83 (Hosmer and Lemeshow 2002). The results are generally consistent with those of McGuire et al. (2012) and Lassila et al. (2010). Notably, audit firm tenure and audit fees are associated with a higher probability that the client will hire the audit firm for tax services, while the magnitude of non-tax, non-audit fees is negatively associated with the probability that the client will hire the audit firm for tax services. The inverse Mills ratio, $I M R$, is calculated from the coefficient estimates reported in Table 4 and included as an additional control variable in models (1) and (2).

Table 5 presents the results from simultaneously estimating models (1) and (2) examining the effect of audit firm tax expertise on the likelihood that firms concentrate on a sustainable or minimization tax strategy. The likelihood ratio test of independence between the two models is significant $(p<0.01)$; thus, simultaneous estimation of the choice of tax strategy 
is appropriate. ${ }^{35}$ I find a positive and significant coefficient on TAXEXPERT $(p<0.05)$ in column (2), indicating that firms with access to expert tax advice have a higher likelihood of focusing on minimization, consistent with Hypothesis 2. In column (4), the average marginal effect for TAXEXPERT suggests that hiring a tax expert audit firm for tax services increases the probability of choosing a minimization tax strategy by $0.033 .{ }^{36}$ The negative, but insignificant coefficient on TAXEXPERT in column (1) implies that expert tax advice is not a significant determinant of the decision to emphasize a sustainable tax strategy. ${ }^{37,38}$

My results in Table 5 are consistent with expert tax advice improving a firm's access to tax planning opportunities, industry-specific information, and innovative tax avoidance activities that can reduce its tax burden. Specifically, I find that hiring a tax expert audit firm for tax services increases the likelihood that a firm focuses on minimization, suggesting that the expertise of tax practitioners (i.e., knowledge of the tax law, the client's industry, and revenue authorities' procedures) improves a firm's ability to achieve the lowest possible tax outcome. In contrast, I find that consulting a tax expert is not associated with implementing a sustainable tax

${ }^{35}$ Furthermore, the estimate of the correlation among the error terms indicates that these two models are significantly, negatively correlated $(p<0.01)$, as expected.

36 The marginal effects presented in columns (3) and (4) are estimated for the regression model that excludes $I M R$. The marginal effects estimation procedures available for bivariate probit regression do not permit the computation of marginal effects for factor (or predicted) variables.

${ }^{37}$ My results are robust to including all of the additional controls from McGuire et al. (2012) - the change in value of the tax loss carryforward; the amount of equity income, cash, and depreciation and amortization expense; the market value of the company relative to the value of all possible clients in the same MSA and industry; Big 4 or second-tier (Grant Thornton or BDO Seidman) audit firms; and prior tax avoidance (i.e., three-year cash ETR calculated over the period $t$-2 to $t$-4).

${ }^{38}$ In an untabulated analysis, I examine whether my results are sensitive to the level of tax fees paid to the auditor. I separately include indicator variables equal to one if tax fees scaled by audit fees is greater than the mean, median, or third quartile and interact that indicator variable with TAXEXPERT. In all instances, I find that neither the tax fee indicator variable, nor the interaction between the tax fee indicator variable and TAXEXPERT are significant. These results indicate that my results are not driven solely by firms paying high tax fees to their auditor, which may be indicative of tax planning (e.g., Dhaliwal et al. 2013). 
strategy. This result suggests that tax experts offer more information about new or industryspecific tax planning techniques, which are not as useful for emphasizing sustainability, than more predictable tax planning opportunities.

\subsection{Hypothesis Three - Information Transfer among Directors}

Table 6 presents the results of simultaneously estimating models (1) and (2) to examine the effect of information transferred through directors' connections on the likelihood that firms concentrate on a sustainable or minimization tax strategy. The likelihood ratio test of independence indicates that the two choices of tax strategy are not independent $(p<0.01)$, suggesting that simultaneous estimation is appropriate. ${ }^{39}$ Consistent with Hypothesis 3 , my results suggest that information transferred through directors' connections is important for the choice of tax strategy. In column (1), I find a negative and significant coefficient on INFO TRANSFER $(p<0.05)$, indicating that firms whose directors have more connections to other directors, greater access to information, and more control over the flow of information have a lower likelihood of focusing on sustainability. The positive and significant coefficient on INFO TRANSFER $(p<0.01)$ in column $(2)$ suggests that information transferred through directors' connections is associated with a higher likelihood of emphasizing minimization. ${ }^{40}$ The average marginal effects reported in columns (3) and (4) indicate that a one unit increase in INFO TRANSFER (i.e., an increase in director connectedness) increases (decreases) the probability of emphasizing minimization (sustainability) by $0.021(0.019)$.

\footnotetext{
${ }^{39}$ Consistent with the prior regressions, the estimate of the correlation among the error terms indicates that the two models are significantly, negatively correlated $(p<0.01)$.

${ }^{40} \mathrm{My}$ results are robust to the inclusion of controls for board characteristics - size, busy directors, and independent directors, as well as prior tax avoidance (i.e., three-year cash ETR calculated over the period $t-2$ to $t-4)$.
} 
My results in Table 6 are consistent with prior research that finds that corporate policies are transferred from one organization to another via connected directors. Specifically, tax planning information from outside sources (i.e., other firms' directors) is useful for enabling firms to reduce their tax burdens. I find that firms with greater access to information through more highly connected directors are less likely to focus on identifying opportunities to maintain a consistent tax outcome (i.e., to choose a sustainable tax strategy) and are more likely to take advantage of the information to reduce taxes and emphasize minimization. Thus, the tax planning information transferred through directors appears to contain relatively more information about new tax planning opportunities, which are useful for minimizing taxes, but not necessarily for obtaining consistent tax outcomes.

\subsection{Relative Importance}

Finally, Table 7 presents the results from simultaneously estimating models (4) and (5) to examine the relative importance of the managerial incentives and practices for firms' tax strategy choices..$^{41,42}$ The likelihood ratio test of independence between the two models indicates that the models are not independent $(p<0.01)$; thus, simultaneous estimation is appropriate. ${ }^{43}$ To determine which factor has the most influence on the choice of tax strategy, I report fully standardized coefficients in Table 7 to permit comparing the relative size of the coefficients. My

\footnotetext{
${ }^{41}$ Including all variables in the model does not pose a multi-collinearity problem. The highest condition index is 28.5, with the relation between SIZE and the intercept contributing significantly to this condition index; however, it is still below the rule of thumb of 30 (Belsley et al. 1980). The second highest condition index is 11.07 , due to the relation between $R O A$ and BTM; thus, I conclude that multicollinearity is not problematic for my analysis.
}

${ }^{42}$ Models (4) and (5) predict firms' choice of tax strategy very well. I perform classification tests by obtaining the predicted probability that the firm engages in a sustainable or minimization tax strategy from the regression analysis presented in Table 7 . Using a cutoff probability of 0.6 , I find that the model correctly classifies firms following a sustainable (minimization) tax strategy 83 (75) percent of the time.

43 The estimate of the correlation among the error terms of the two regressions indicates that the error terms of the two models are significantly, negatively correlated $(p<0.01)$, consistent with the decision to focus on one tax strategy reducing the likelihood that the firm also focuses on the other tax strategy. 
results are consistent with the separate tests of each factor reported above (i.e., all coefficients retain the same sign and level of significance). ${ }^{44}$ In column (1), the coefficient on DELTA (INFO TRANSFER) is positive (negative) and significant ( $p<0.01$ and $p<0.05$, respectively). The coefficients on VEGA, TAXEXPERT, and INFO TRANSFER are all positive and significant in column $(2)(p<0.01, p<0.05$, and $p<0.10$, respectively).

The results in Table 7 suggest that the sensitivity of the CEO's wealth to stock price (DELTA) is relatively more important than information from directors' connections (INFO TRANSFER $)$ to the decision to emphasize sustainability $(Z=2.16, p<0.05) .{ }^{45}$ Furthermore, firms that focus on minimization are influenced most by equity incentives (VEGA), followed by expert tax advice, and finally, information from directors' connections. Tests of the difference in the coefficients demonstrate that the coefficient on VEGA is significantly larger than the coefficients on both TAXEXPERT and INFO TRANSFER $(Z=2.48$ and $-1.72, p<0.01$ and $p<$ 0.05 , respectively), indicating that equity incentives influence the choice of a minimization tax strategy to a greater extent than expert tax advice or information from directors' connections. Furthermore, the coefficient on TAXEXPERT is also significantly larger than the coefficient on INFO TRANSFER $(Z=1.29, p<0.10)$, suggesting that expert tax advice influences an emphasis on minimization more than information from directors' connections.

The prior literature has separately documented associations between the level of tax avoidance (i.e., cash or GAAP ETRs) and equity incentives, audit firm tax expertise, and board interlocks (however, not director connectedness), but has not considered whether these factors

\footnotetext{
${ }^{44}$ The only coefficient that has a lower level of significance is the coefficient on INFO TRANSFER in column (2). This coefficient was significant at the one percent level in Table 6 and is now only marginally significant; however, my overall conclusions remain unchanged.

${ }^{45}$ I test the equality of the regression coefficients following equation (4) of Paternoster et al. $(1998,862)$. Specifically, the $Z$-statistic is equal to the difference in the regression coefficients divided by the square root of the sum of the squared standard errors for the two regression coefficients.
} 
are important for explaining a firm's tax strategy choice or are incremental to one another in determining this choice. The results of my relative importance analysis establish that, for tax strategy, each of these factors is incremental to others. Furthermore, among the variables of interest, my results suggest that, in general, equity incentives are the most important determinants of tax strategy choice, followed by the practices of obtaining external information from tax experts or from directors at other firms. My results demonstrate that equity incentives are not only associated with tax outcomes, as provided in the prior literature, but are the primary determinants of tax strategy choice, which produces the observed tax outcomes. Furthermore, managerial incentives outweigh the effects of management practices on those same tax outcomes. 


\section{ADDITIONAL ANALYSIS}

\subsection{Matched Firm Analysis}

The income and expenses arising from different activities (e.g., acquiring a new asset versus operating in a foreign country) are not always treated similarly for tax purposes; thus, the tax benefits of various activities may not be equal (Inger 2014), leading firms to have different tax planning opportunity sets (Mills et al. 1998). A firm's tax planning opportunities can affect its chosen tax strategy. Therefore, firms with sustainable tax strategies may have different tax planning opportunities relative to firms with minimization tax strategies, which could generate differences in managerial incentives and practices across the two sets of firms and potentially explain my findings. Because tax planning opportunities are related to firm characteristics, I also conduct my analysis using a matched sample, which holds tax planning opportunities constant while examining the influence of managerial incentives and practices on tax strategy choice.

To create a sample for this analysis, I match firms following sustainable tax strategies $(S U S T A I N=1)$ to firms following minimization tax strategies $(M I N I M I Z E=1)$ without replacement on SIZE within both industry (Fama-French 17 classification) and year. This procedure yields a sample of 1,998 firm-year observations (999 unique matched pairs). Utilizing this matched sample, I re-examine my hypotheses using a logistic regression where the dependent variable is SUSTAIN and the independent variables are as previously defined. The results of this analysis are presented in Table 8.

In all four columns of Table 8, the coefficient on SIZE is no longer significant, indicating that the matching procedure resulted in a good match; however, to control for any 
residual bias due to imperfect matching, I include SIZE in each regression. ${ }^{46}$ Similar to the results of my main analyses, I find a positive and significant coefficient on DELTA $(p<0.01)$, suggesting that firms with CEOs whose wealth is more sensitive to changes in the stock price are more likely to implement a sustainable tax strategy relative to a minimization tax strategy. I also find negative and significant coefficients on TAXEXPERT and INFO TRANSFER (both $p<$ 0.05). These results indicate that firms with access to expert tax advice or with more wellconnected directors are less likely to emphasize sustainability and more likely to concentrate on minimization, consistent with the results of my analysis in Tables 3 through 7 . Thus, my results suggest that tax planning opportunities are not the only determinant of tax strategy choice.

Furthermore, differences in opportunity sets do not subsume the association between managerial incentives and practices and tax strategy choice, holding these opportunities constant, managerial incentives and practices continue to be significant determinants of firms' tax strategy choices.

\subsection{Firm Value Analysis}

Consistent with Scholes et al. (2009), I defined tax strategy as a pattern of decisionmaking and actions with respect to tax planning that maximizes after-tax returns and firm value and investigated two dimensions of tax strategy presented in recent empirical and anecdotal evidence, sustainability and minimization (e.g., Deloitte LLP 2013; KPMG LLP 2007; McGuire et al. 2013). Because the strategy literature suggests that there are multiple methods for achieving the goal of any strategy and that firms will choose a strategy that suits its situation (Hambrick 1983; Miller 1987; Porter 2004; Zahra and Covin 1993), I implicitly assume that both sustainability and minimization create value for firms. In this analysis, I test this assumption by

\footnotetext{
${ }^{46}$ In addition to matching on SIZE, I also matched firms within industry and year on SIZE and LEVERAGE and SIZE, LEVERAGE, and TLCF, respectively. Conducting the analysis with these two matched samples yields inferences that are consistent with those reported in Table 8 (i.e., the sign and significance of all variables of interest remains the same).
} 
examining whether firms that choose either a sustainable or minimization tax strategy exhibit a higher market value of equity relative to firms with a mixed tax strategy (i.e., a tax strategy with attributes of both sustainability and minimization).

Specifically, I conduct a univariate analysis, presented in Table 9, in which I test the differences in the mean and median values of market value of equity $(M V E)$ for firms following a sustainable or minimization tax strategy relative to other firms that have not clearly established one of these tax strategies. MVE is calculated as the product of the number of common shares outstanding and the stock price measured on the last day of the fiscal year, scaled by end-of-year total assets. I measure $M V E$ in the current year, as well as in the three subsequent years. Panel A (B) of Table 9 presents the results of tests of mean and median differences in $M V E$ for firms following a sustainable (minimization) tax strategy relative to firms that choose a mixed tax strategy. I find that firms following a sustainable tax strategy have significantly higher $M V E$ than firms following a mixed tax strategy in both the current and subsequent years (all $p<0.01$ ), suggesting that a sustainable tax strategy is associated with higher firm value. Similarly, in Panel B, I find that firms following a minimization tax strategy also have significantly higher current and future $M V E$ relative to firms classified as following a mixed tax strategy (all $p<$ 0.01 ), suggesting that minimization is also associated with greater firm value.

Taken together, the results presented in Table 9 indicate that firms that explicitly choose a tax strategy have higher market values than firms with tax strategies that are not well defined, supporting the argument presented in the strategy literature that any dimension of a strategy can be value-maximizing. My results do not quantify the direct impact that tax strategy choice has on firm value. However, these results do suggest that firms that choose a specific tax strategy are more valuable in general, implying that managers are making value-creating decisions and suggesting that the choice of tax strategy is important for maximizing firm value. 


\subsection{Forward Tax Strategy Analysis}

I investigate the association between tax strategy choice and contemporaneous values of managerial incentives and practices to capture the timeliness and relevance of new information received during the current year, as well as the accumulation and rebalancing of equity incentives on an annual basis. However, strategy decisions are sticky (e.g., Bentley et al. 2012). As discussed previously, although firms can and do change their tax strategies, a firm's tax strategy choice is relatively stationary over time. ${ }^{47}$ Thus, I also investigate firms' future tax strategy choices to examine the extent to which current managerial incentives and practices influence future decisions.

To investigate firms' future tax strategy choices, I regress my proxies for firms' tax strategies measured at a future date on current period values of managerial incentives and practices and controls. Specifically, I re-estimate models (4) and (5) using SUSTAIN and MINIMIZE measured at three alternative points in time, one-, two-, and four-years ahead. ${ }^{48}$ The estimated coefficients on the variables of interest represent the association between current period managerial incentives and practices and future tax strategy choice. A significant coefficient indicates that not only are current period incentives and practices determinants of this year's choice of tax strategy, but that their influence also carries over into future choices.

Table 10 presents the results of my analysis. In columns (1) and (2), the choice of tax strategy is measured in year $t+1$. I find negative and significant coefficients on $V E G A$ and $I N F O$ TRANSFER in column (1) $(p<0.01$ and $p<0.10$, respectively), which suggests that firms whose

\footnotetext{
${ }^{47}$ Approximately 64 (75) percent of firms in my sample are classified as following a sustainable (minimization) tax strategy for 50 percent of their firm-year observations.

${ }^{48}$ I measure tax strategy as far as four years into the future because five years of data is required to measure $C V \_C E T R$. Thus, in year $t+4, C V_{-} C E T R$ is comprised of cash ETRs from years $t+4$ to $t$, which ensures that the tax strategy is measured using only current and future tax outcomes.
} 
CEOs are compensated for stock return volatility or firms with more well-connected directors are less likely to choose a sustainable tax strategy. In column (2), I find positive and significant coefficients on VEGA and TAXEXPERT ( $p<0.01$ and $p<0.05$, respectively), indicating that firms whose CEO's wealth is more sensitive to changes in stock return volatility and firms with access to expert tax advice are more likely to implement a minimization tax strategy.

Collectively, these results (and my inferences) are consistent with those reported in my main analysis and suggest that current period managerial incentives and practices influence the choice of tax strategy in the next period.

Columns (3) and (4) present the results using tax strategy measured in year $t+2$, and columns (5) and (6) present the results when tax strategy choice is measured in year $t+4$. In both analyses, I find positive and significant coefficients on DELTA and negative and significant coefficients on TAXEXPERT for SUSTAIN (all $p<0.10$ ), which indicates that firms whose CEO's wealth is more sensitive to changes in the stock price are more likely to choose a sustainable tax strategy, but firms with access to expert tax advice are less likely to emphasize sustainability. In columns (4) and (6), I find positive and significant coefficients on VEGA for MINIMIZE (both $p<0.01$ ), implying that firms whose CEOs are rewarded for stock return volatility are more likely to implement a minimization tax strategy. In combination, the results of Table 10 confirm that current period managerial incentives and practices have predictability for future tax strategy choice; however, they also showcase the importance of considering the contemporaneous association to more completely incorporate the influence that these factors have on the choice of tax strategy.

In conjunction with my main analysis, I find that current period managerial incentives and practices are associated with both current and future tax strategy choices, implying that these factors likely influence both one-time tax planning activities and changes to tax planning, as well 
as recurring tax avoidance activities. Furthermore, as expected, I find that the associations attenuate as tax strategy is measured further out in time, but in a manner consistent with the results of my relative importance analysis. Specifically, I find that managerial incentives continue to be highly significant predictors of the choice of tax strategy four-years ahead, but director connectedness is no longer significantly associated with tax strategy choice and the significance of expert tax advice is lessened. This attenuation parallels my findings in Table 7 that, within these factors, managerial incentives are the most important determinants of tax strategy choice followed by obtaining expert tax advice and information from directors' connections.

\subsection{Tax Strategy Classification using GAAP ETR}

I define tax strategies using cash ETRs because firms' tax strategies should ultimately manifest in cash outflow to taxing authorities. Firms have less discretion in the calculation of taxable income than in the calculation of financial statement income (Hanlon et al. 2005), and prior literature finds numerous instances in which firms manage earnings to meet benchmarks or to present a more favorable picture of their performance (see Dechow et al. (2010) for a review of the literature). Thus, to more clearly identify firms' tax strategies, I classified firms using measures based upon cash ETRs. However, the prior literature provides evidence that many firms are concerned about the ETR reported on the financial statements, or GAAP ETR. For example, managers are incentivized to reduce GAAP ETRs (Phillips 2003; Robinson et al. 2010; Armstrong et al. 2012), and firms with CEOs whose bonuses are determined by after-tax performance measures report lower GAAP ETRs (Powers et al. 2013). Because GAAP ETRs may be the tax benchmark of interest for some firms, I extend my main analysis by investigating whether managerial incentives and practices are associated with the choice of tax strategy, where tax strategy is defined using GAAP ETRs. 
For this analysis, I define sustainable and minimization tax strategies in terms of GAAP ETRs. Specifically, I classify a firm as following a sustainable tax strategy for financial statement purposes if its coefficient of variation of annual GAAP ETRs ( $\left.C V \_G E T R\right)$ measured over the five-year period, $t$ to $t-4$, is in the lowest quintile for the year and as following a minimization tax strategy for financial statement purposes if its three-year GAAP ETR (GETR3) measured over the period $t$ to $t-2$ is less than or equal to 20 percent. Tax expense and cash taxes paid are products of significantly different calculations subject to different levels of judgment. Consistent with these two measures representing different aspects of firms' tax burdens, an examination of the overlap of tax strategy defined using cash ETRs and GAAP ETRs reveals that the two classification schemes result in identifying different samples of firms focusing on sustainability and minimization (i.e., approximately 51 (35) percent of firms classified as following a sustainable (minimization) tax strategy using cash ETRs are also classified as following that tax strategy using GAAP ETRs). Because of these differences, I define firms as following sustainable or minimization tax strategies if both cash and GAAP ETRs indicate the same tax strategy choice and re-estimate models (4) and (5) to examine the influence of managerial incentives and practices on firms' choice of tax strategy.

Table 11 reports the results of this additional analysis - the regression results for SUSTAIN are presented in column (1), while the results for MINIMIZE are presented in column (2). My results with respect to expert tax advice and director connectedness are similar to those reported in my primary analysis. Specifically, in column (2), I find positive and significant coefficients on TAXEXPERT $(p<0.05)$ and INFO TRANSFER $(p<0.10)$, indicating that firms with access to expert tax advice or with more well-connected directors are more likely to implement a minimization tax strategy. I find a negative and significant coefficient on INFO TRANSFER in column $(1)(p<0.01)$, which suggests that firms with more well-connected 
directors are less likely to emphasize sustainability. Thus, my inferences regarding the effect of these managerial practices on firms' tax strategy choices are unchanged when tax strategy is measured using GAAP ETRs. However, although the positive coefficient on DELTA (VEGA) in column (1) (column (2)) implies that firms whose CEOs' wealth is more sensitive to changes in the stock price (stock return volatility) are more likely to implement a sustainable (minimization) tax strategy, neither coefficient is statistically significant at conventional levels. Therefore, my results regarding managerial incentives are attenuated when I measure tax strategy using GAAP ETRs, but my analysis indicates that managerial practices are significant determinants of firms' tax strategy choices regardless of the measurement of tax strategies.

\subsection{Mixed Tax Strategy Analysis}

The strategy literature suggests that it is almost impossible for a firm to fully emphasize two dimensions of a strategy at once (March 1991). Therefore, consistent with prior studies (e.g., Bentley et al. 2012; Higgins et al. 2014), I have focused on identifying and examining those firms that choose a salient tax strategy. However, although difficult to implement effectively, firms can have mixed strategies which incorporate elements of multiple dimensions of a strategy (Miles et al. 1978; Porter 2004). A sizeable portion of my sample is not classified as following either a sustainable or a minimization tax strategy, which suggests that there are a number of firms that pursue a mixed tax strategy. Therefore, to provide initial evidence on these firms, I also investigate whether managerial incentives and practices influence the choice of a mixed tax strategy (i.e., a tax strategy with elements of both sustainability and minimization).

I conduct both univariate and multivariate analyses of the firms that choose to implement a mixed tax strategy. I define a firm as following a mixed tax strategy (i.e., MIXED equal to one) if both SUSTAIN and MINIMIZE are equal to zero. Table 12 presents descriptive statistics for each tax strategy group and univariate tests of mean and median differences 
between the groups. Panel A compares firms emphasizing sustainability to firms following a mixed tax strategy. I find that mixed tax strategy firms are smaller, more likely to report a TLCF, have more volatile pre-tax book income, and engage in more $R \& D$ than firms following a sustainable tax strategy (all $p<0.01$ ). In Panel B, I find that firms identified as implementing a mixed tax strategy are more capital intensive and segmented, less likely to have foreign operations or report a TLCF, have less volatile pre-tax book income, and engage in less R\&D than firms concentrating on minimization (all $p<0.05$ ). Thus, firms following a mixed tax strategy share some characteristics and differ on others relative to firms choosing a more salient tax strategy, which is consistent with these firms incorporating elements of both sustainable and minimization tax strategies.

To examine the association between managerial incentives and practices and the choice of a mixed tax strategy, I employ a multinomial logistic regression to compare the effect of a managerial incentive or practice on the likelihood that a firm chooses a mixed tax strategy relative to either a sustainable or minimization tax strategy. ${ }^{49}$ In general, my analysis, presented in Table 13, indicates that the coefficient on the variable of interest for the mixed tax strategy firms is significant in the opposite direction of the coefficient previously reported for the base group (either SUSTAIN or MINIMIZE). Specifically, in columns (1) and (2), when the base group for comparison is SUSTAIN, I find a negative and significant coefficient on DELTA $(p<$ 0.05), which suggests that firms whose CEOs' wealth is more sensitive to changes in the stock price are less likely to implement a mixed tax strategy relative to a sustainable tax strategy. Similarly, in columns (3) and (4) when MINIMIZE is the base group for comparison, I find

\footnotetext{
49 To investigate whether these managerial incentives and practices are equally relevant for all tax strategies, I conduct a factor analysis of my four proxies for each tax strategy subsample. I find similar factor loadings for each variable within the three subsamples, which suggests that the manner in which these factors influence the choice of tax strategy is similar for all tax strategies. Thus, these factors are relevant to the choice of any tax strategy.
} 
negative and significant coefficients on VEGA, TAXEXPERT, and INFO TRANSFER (all $p<$ 0.05). These results indicate that firms with CEOs who are compensated for stock return volatility or firms that have access to expert tax advice or highly connected directors are less likely to choose a mixed tax strategy relative to focusing on minimization. Collectively, my results indicate that the effect of managerial incentives and practices on the choice of a mixed tax strategy falls near the middle of the effect of these factors on the choice of a sustainable or minimization tax strategy, consistent with these firms incorporating elements of both dimensions of tax strategy.

\subsection{Both Tax Strategy Analysis}

Although the strategy literature suggests that it is difficult, if not almost impossible, for a firm to emphasize two dimensions of a strategy at once (March 1991), there are firms that are successful at achieving a multi-dimensional approach to a strategy's objective. Consistent with there being some, but relatively few, firms capable of achieving this feat, I identify 187 observations in my sample that are classified as following both a sustainable and a minimization tax strategy. These firm-year observations comprise only four percent of my sample. However, this sample represents a unique set of firms that are successful at achieving a difficult goal, and thus, presents an interesting opportunity to learn more about firms that are able to simultaneously emphasize two dimensions of a strategy.

Given the small sample of observations that emphasize both sustainability and minimization, I focus on univariate tests, presented in Table 14, to examine the similarities and differences of this sample relative to firms that focus exclusively on sustainability (Panel A) or minimization (Panel B). Based on differences in the mean and median values of $C V \_C E T R$ and CETR3, firms that pursue both dimensions of tax strategy have more volatile annual cash ETRs than firms that solely emphasize sustainability and higher three-year cash ETRs than firms that 
primarily focus on minimization (all $p<0.01$ ). These univariate tests suggest that firms that emphasize sustainability and minimization simultaneously are more moderate than those firms that only pursue one dimension of tax strategy in terms of both the level and variability of tax avoidance. Given the difficulty of emphasizing multiple dimensions of a strategy, as portrayed by the prior literature, this more moderate approach to both dimensions seems necessary.

With respect to firm characteristics, these firms are larger and more segmented with higher signed values of discretionary accruals than firms focusing on either sustainability or minimization (all $p<0.01$ ). However, relative to firms with sustainable tax strategies, firms that emphasize both tax strategy dimensions engage in more $\mathrm{R} \& \mathrm{D}(p<0.01)$, but are not different with respect to firm performance. Relative to firms with minimization tax strategies, firms that focus on both dimensions of tax strategy have higher performance (all $p<0.01$ ), but do not differ on the level of investment in R\&D. Thus, these firms appear to have more flexibility and more available tax planning opportunities, which permits minimizing their tax burdens consistently over time. It is also important to note that, on average, relative to either firms with sustainable or minimization tax strategies, firms that emphasize both dimensions of tax strategy have higher values of managerial incentives and practices (all $p<0.10)$. This result suggests that, not only do these firms appear to have the resources and capabilities to focus on both sustainability and minimization, but they also have the necessary incentives and practices in place to encourage managers to focus on both dimensions of tax strategy, a rare combination that allows them to achieve a difficult task. 


\section{ROBUSTNESS TESTS}

\subsection{Alternative Specification of Minimization}

I examine the sensitivity of my measure of a minimization tax strategy to different measurement periods because prior research has also used five and ten years to measure tax avoidance (e.g., Dyreng et al. 2008). Specifically, I categorize a firm as following a minimization tax strategy if its five-year cash ETR is less than or equal to 20 percent. Using this alternative proxy, all variables of interest maintain the same sign and level of significance with the exception of INFO TRANSFER in model (2), which remains positive, but is no longer significant at conventional levels. However, my overall inferences are the same; thus, I conclude that my results are robust to measuring minimization over a longer period.

\subsection{Removal of Non-Tax Planning Firms}

It may be less costly for firms with extremely high non-tax costs to forego tax avoidance and pay tax at the top corporate statutory tax rate. Because these firms will consistently pay high taxes, they could potentially be classified as emphasizing sustainability. To ensure that my results, particularly those for sustainable tax strategies, are not due to firms that are not engaging in tax planning, I restrict my sample to observations that have a CETR3 less than 35 percent and re-estimate my regression models. Using this restricted sample, my conclusions are unchanged. All variables of interest maintain the same sign and level of significance with the exception of INFO TRANSFER in model (5), which remains positive, but is no longer statistically significant. However, considered in conjunction with the negative and significant coefficient on INFO TRANSFER in model (4) when SUSTAIN is the dependent variable, my inferences are the same. Thus, my results are robust to excluding firms that do not engage in tax planning. 


\subsection{Controlling for Business Strategy and Life Cycle}

The management literature indicates that the individual strategies within firms are aligned to achieve the firm's overall objectives (Miller 1986; Porter 2004; Zahra and Covin 1993); thus, firms' tax strategies may be linked to their business strategies. Similarly, firms undergo changes as they progress through their life cycles from introduction to maturity, and ultimately, decline (Gort and Klepper 1982), which will influence their operations and may also alter their approaches to tax planning and tax strategy (Drake 2013). Therefore, I examine the sensitivity of my results to including proxies for firms' business strategy (Bentley et al. 2012) and life cycle (Dickinson 2011). My results are robust to the inclusion of these additional control variables. All of my inferences remain the same (i.e., all coefficients of interest retain the same sign and level of significance). Furthermore, business strategy is not a significant predictor of firms' tax strategy choice, and the proxies for life cycle are not statistically significant in a consistent manner.

\subsection{Controlling for Influential Tax Strategy Changes}

Within my sample, firms' tax strategy choices are relatively stable over time. There are no firms that switch from a sustainable tax strategy to a minimization tax strategy or vice versa, but firms do shift in and out of the two tax strategy classifications, usually by moving slightly toward the middle of the distribution. However, examining year-over-year changes reveals 82 observations that shift more than one quintile of $C V \_C E T R$ and 260 observations that experience a change in CETR 3 of more than 10 percent. I investigate the robustness of my results to these potentially influential changes in tax strategy by including two indicator variables in my analysis that identify firm-year observations in which a significant shift in sustainability or minimization occurred. Controlling for the 342 observations whose tax strategies appear to have shifted 
drastically, my inferences are unchanged (i.e., all coefficients of interest retain the same sign and level of significance).

\subsection{Factor Analysis}

Because managerial incentives and practices collectively guide decision-making, they are unlikely independent of one another. Indeed, my analysis indicates that some factors work in conjunction with one another, suggesting that a firm's decision-making policy has two aspects caution and risk-taking. My analysis in Table 7 accounts for some of the interdependence of the proxies by including all four variables simultaneously, but maintains that they are somewhat independent as they enter the regression as separate covariates. To measure the joint effect of the incentives and practices and model the caution and risk-taking aspects of decision-making policy, I use principal components factor analysis to create two factor scores. I model caution using the factor score from combining DELTA and the reverse-coded measure of INFO TRANSFER (CAUTION) and risk-taking using the factor score from combining VEGA and INFO TRANSFER (RTAKING). ${ }^{50}$

I exclude TAXEXPERT from the principal components analysis because it is obtained through a different process. Companies have complete control over the incentives provided to managers and directors' connections because they can change the compensation contract and hire and fire directors. In contrast, the company has less control over whether their audit firm is a tax expert. The distribution of tax expertise is driven by audit firm willingness to invest in becoming an expert, and the ultimate pairing of audit firm and client depends on many things client needs, conflicts of interest, availability, etc. - only one of which is tax strategy. Thus,

\footnotetext{
${ }^{50}$ I create the factor scores in this manner because my main analysis suggests that DELTA and INFO TRANSFER work oppositely to promote increasing firm value with relatively low risk, while VEGA and INFO TRANSFER work together to encourage increasing firm value through relatively more risky investments.
} 
obtaining expert tax advice follows a different process than providing equity incentives or transferring information through director connections. ${ }^{51}$

I examine the effect of CAUTION, RTAKING, and TAXEXPERT by re-estimating models (4) and (5) including one factor score and TAXEXPERT. Accounting for the joint effect of managerial incentives and practices, my untabulated analysis suggests that TAXEXPERT and RTAKING (CAUTION) positively (negatively) influence the choice of a minimization tax strategy, while CAUTION positively influences the choice of a sustainable tax strategy (all $p<$ 0.05). Thus, consistent with my main analysis, these results suggest that firms take deliberate actions to cultivate decision-making policies that reflect their attitudes toward tax strategies.

\subsection{Nearby Firm Analysis}

I defined sustainable and minimization tax strategies using portions of the distribution of tax behavior observed over time (i.e., lowest quintile of $C V_{-} C E T R$ and CETR3 less than or equal to 20 percent). Although my operationalizations are consistent with the conceptual definitions of tax strategy, my cut-offs are somewhat arbitrary. However, if my classification adequately represents each tax strategy, I would expect managerial incentives and practices to influence the choice of tax strategy differently for firms exhibiting tax behavior close to sustainability or minimization (i.e., those firms that lie nearby on the distribution of tax behavior). To investigate this expectation, I re-estimate models (4) and (5) using dependent variables that denote firms near the ends of the distribution (i.e., SUSTAIN equals one if the firm is in the second lowest quintile of $C V \_C E T R$ and zero otherwise, while MINIMIZE equals one is the firm has a CETR3 greater than 20 percent, but less than 30 percent). I find that none of my proxies for managerial incentives and practices are significantly associated with tax strategies close to sustainable or

\footnotetext{
${ }^{51}$ When I include TAXEXPERT in the factor analysis, it loads positively on the factor (0.438), but its
} uniqueness is rather high (0.808), consistent with TAXEXPERT not being fully controlled by the firm. 
minimization tax strategies. Consistent with the lack of a clear tax strategy, my results (untabulated) indicate that the nearby firms do not behave in the same manner as the firms with more salient tax strategies, reiterating the importance of identifying firms that clearly choose a tax strategy for examining the determinants of tax strategy choice.

\subsection{CEO Change Analysis}

Because managerial incentives and practices are determined by the shareholders and board of directors, I have implicitly assumed that firms' strategies are determined by the firm as a whole rather than by any one manager. However, it is possible that a change in CEO could result in a significant shift in a firm's strategy, including its tax strategy, because the CEO can exert considerable influence over the firm (e.g., Dyreng et al. 2010; Bertrand and Schoar 2003; Bamber et al. 2010). Therefore, I examine the sensitivity of firms' tax strategy choices to CEO changes.

I identify 490 firm-year observations in my sample that experience a change in CEO in the prior year. Approximately ten percent of observations in each tax strategy (sustainable, minimization, and mixed) have a CEO change (10.7, 10.4, and 10.5 percent, respectively), suggesting that CEO changes are not systematically related to one tax strategy. I also compare the difference in the average change in tax strategy in the year following a change in CEO to the average change in tax strategy for all other firm-year observations. The average change in SUSTAIN is 0.139 (0.121) for firm-year observations with (without) a CEO change in the prior year, and this difference is not statistically significant $(p=0.26)$. Similarly, the average change in MINIMIZE is 0.152 (0.149) for firm-year observations with (without) a CEO change in the prior year, which is not statistically significantly $(p=0.89)$. In addition, there are no firms that change from a sustainable tax strategy to a minimization tax strategy, or vice versa, in the year following the change in CEO. Taken together, my results indicate that, in general, CEO changes 
do not impact firms' tax strategy choices, consistent with the findings of the business strategy literature (Bentley 2013; Higgins et al. 2014).

\subsection{Consistent Expense Analysis}

The management literature suggests that each individual strategy within the firm is chosen to align with the firm's overarching strategy (Miller 1986; Porter 2004; Zahra and Covin 1993). If strategies are aligned, I expect firms that choose a sustainable tax strategy to also report consistent levels of other expenses. Thus, I investigate the variability of two other commonly reported expenses, cost of goods sold (COGS) and selling, general, and administrative expenses (SG\&A), and their association with tax strategy choices. For each observation in my sample, I calculate the coefficient of variation for COGS and SG\&A over the period $t-4$ to $t$ and conduct tests of mean and median differences for firms that engage in sustainable, mixed, or minimization tax strategies. My untabulated analysis indicates that firms that choose a sustainable tax strategy have significantly lower coefficients of variation for both COGS and SG\&A than firms that engage in either of the two remaining tax strategies (all $p<$

0.01). These results suggest that firms that emphasize sustainability consistently make decisions that result in less volatile expenses, indicating that managers employ similar strategies across the entire firm. 


\section{CONCLUSION}

This study examines the managerial incentives and practices associated with firms' decisions to concentrate on a sustainable or minimization tax strategy and their relative importance as determinants of firms' tax strategy choices. The sustainability dimension strives to achieve a consistent tax outcome over time, while the minimization dimension strives to achieve the lowest possible tax outcome. The goal of effective tax planning, and thus tax strategy, is to maximize after-tax returns. Therefore, understanding the determinants of firms' tax strategy choices is important because tax strategy can contribute significantly to firm value, but researchers know relatively little about why firms choose their tax strategy.

I draw upon prior literature that posits that managerial incentives and practices are significant determinants of managers' decision-making, in general (e.g., Jensen and Meckling 1976), and tax strategy, specifically (e.g., Dyreng et al. 2008; Mills et al. 1998). Using a sample of firm-year observations from 2000 to 2010 , I find that firms are more likely to focus on a sustainable tax strategy when the CEO's wealth is more sensitive to changes in stock price (i.e., incentivized to increase firm performance) and less likely to emphasize sustainability when it has more access to information through its directors' connections. In contrast, firms are more likely to concentrate on a minimization tax strategy when the CEO's wealth is more sensitive to changes in stock return volatility (i.e., incentivized to make riskier decisions), when a tax expert audit firm provides tax services, or when firms have more access to information through their directors' connections. Finally, I find that managerial incentives are the most important factors for the choice of tax strategy followed by the managerial practices of obtaining expert tax advice and information from directors outside of the firm. Unlike prior literature that documents an association between managerial incentives and tax outcomes, I provide evidence that managerial 
incentives are the most important factor preceding the tax strategy choice, which produces the observed tax outcomes.

This study contributes to the literature that examines the determinants of corporate tax avoidance by investigating two dimensions of tax strategy and the determinants of the underlying tax strategy (i.e., the decision to emphasize either a sustainable or minimization tax strategy to maximize firm value). Prior research has sought to explain the variation in tax outcomes; however, by examining the factors that likely precede the choice of tax strategy, I provide evidence regarding which managerial incentives and practices influence this higher-level tax planning decision. Furthermore, although the prior literature has identified many characteristics associated with firms' tax avoidance, much of the variation in tax outcomes has yet to be explained (Hanlon and Heitzman 2010; Shevlin 2007). By identifying the determinants of tax strategy choice, this study can further explain the variation in observed tax outcomes because the tax outcomes depend on firms' tax strategies. Finally, my findings may be of interest to firms and shareholders because they indicate that managerial incentives and practices can be used to influence the choice of tax strategy; thus, shareholders that desire to alter an existing strategy or implement a new tax strategy may find these mechanisms useful for accomplishing their goal. 


\section{REFERENCES}

AFL-CIO. 2013. Trends in CEO pay at S\&P 500 index companies. Available at: http://www.aflcio.org/Corporate-Watch/CEO-Pay-and-You/Trends-in-CEO-Pay.

Agresti, A. 2007. An Introduction to Categorical Data Analysis. $2^{\text {nd }}$ ed. Hoboken, NJ: WileyInterscience.

American Taxation Association (ATA). 2014. Corporate tax directors: Managing tax risk and the relationship with the audit committee. Presented at the mid-year meeting of the American Taxation Association, San Antonio, TX.

Andres, C., and M. Lehmann. 2010. Is busy really busy? Board governance revisited. Working paper, University of Mannheim.

Armstong, C., J. Blouin, and D. Larcker. 2012. The incentives for tax planning. Journal of Accounting and Economics 53 (1-2): 391-411.

Ayers, B., J. Jiang, and S. Laplante. 2009. Taxable income as a performance measure: The effects of tax planning and earnings quality. Contemporary Accounting Research 26 (1): $15-54$.

Badertscher, B., J. Phillips, M. Pincus, and S. Rego. 2009. Earnings management strategies and the trade-off between tax benefits and detection risk: To conform or not to conform? The Accounting Review 84 (1): 63-97.

Bamber, L., J. Jiang, and I. Wang. 2010. What's my style? The influence of top managers on voluntary corporate financial disclosure. The Accounting Review 85 (4): 1131-1162.

Barnea, A., and I. Guedj. 2009. Director networks. Working paper, University of Texas at Austin.

Barth, M., J. Elliot, and M. Finn. 1999. Market rewards associated with patterns of increasing earnings. Journal of Accounting Research 37 (2): 387-413.

Belsley, D., E. Kuh, and R. Welsch. 1980. Regression Diagnostics: Identifying Influential Data and Sources of Collinearity. New York, NY: John Wiley.

Bentley, K. 2013. Antecedents to financial statement misreporting: The influence of organizational business strategy, ethical culture and climate. Working paper, University of New South Wales.

Bentley, K., T. Omer, and N. Sharp. 2012. Business strategy, financial reporting irregularities, and audit effort. Contemporary Accounting Research 30 (2): 780-817. 
Bertrand, M. and A. Schoar. 2003. Managing with style: The effects of managers on firm policies. The Quarterly Journal of Economics 118 (4): 1169-1208.

Bizjak, J., M. Lemmon, and R. Whitby. 2009. Option backdating and board interlocks. Review of Financial Studies 22 (11): 4821-4847.

Bonaccio, S. and R. Dalal. 2006. Advice taking and decision-making: An integrative literature review, and implications for the organizational sciences. Organizational Behavior and Human Decision Processes 101 (2): 127-151.

Bonacich, P. 1987. Power and centrality: A family of measures. American Journal of Sociology 92 (5): 1170-1182.

Bonner, S., J. Davis, and B. Jackson. 1992. Expertise in corporate tax planning: The issue at the identification stage. Journal of Accounting Research 30 (Supplement): 1-28.

Borgatti, S. and D. Halgin. 2011. On network theory. Organization Science 22 (5): 1168-1181.

British Broadcasting Corporation (BBC). 2013. Starbucks pays UK corporate tax for first time since 2009. Available at: http://www.bbc.com/news/uk-politics-23019514.

Brown, J. 2011. The spread of aggressive corporate tax reporting: A detailed examination of the corporate-owned life insurance shelter. The Accounting Review 86 (1): 23-57.

Brown, J. and K. Drake. 2013. Network ties among low-tax firms. Working paper, Arizona State University and University of Arizona.

Cappellari, L., and S. Jenkins. 2003. Multivariate probit regression using simulated maximum likelihood. The Stata Journal 3 (3): 278-294.

Chava, S. and A. Purnanandam. 2010. CEOs versus CFOs: Incentives and corporate policies. Journal of Financial Economics 97 (2): 263-278.

Cloyd, B. 1995. The effects of financial accounting conformity on recommendations of tax preparers. The Journal of the American Taxation Association 17 (2): 50-70.

Cloyd, B., J. Pratt, and T. Stock. 1996. The use of financial accounting choice to support aggressive tax positions: Public and private firms. Journal of Accounting Research 34 (1): 23-43.

Coles. J., N, Daniel, and L. Naveen. 2006. Managerial incentives and risk-taking. Journal of Financial Economics 79 (2): 431-468.

Cook, K., W. Moser, and T. Omer. 2014. Towards an optimal level of tax avoidance. Working paper, Texas Tech University, Miami University, and University of Nebraska-Lincoln.

Core, J. and W. Guay. 1999. The use of equity grants to manage optimal equity incentive levels. Journal of Accounting and Economics 28 (2): 151-184. 
Davis, G., and H. Greve 1997. Corporate elite networks and governance changes in the 1980s. American Journal of Sociology 103 (1): 1-37.

Davis, G., M. Yoo, and W. Baker. 2003. The small world of the American corporate elite, 19822001. Strategic Organization 1 (3): 301-326.

DeAngelo, H., L. DeAngelo, and D. Skinner. 1996. Reversal of fortune: Dividend signaling and the disappearance of sustained earnings growth. Journal of Financial Economics 40 (3): 341-371.

Dechow, P. and I. Dichev. 2002. The quality of accruals and earnings: The role of accrual estimation errors. The Accounting Review 77 (Supplement): 35-59.

Dechow, P., W. Ge, and C. Schrand. 2010. Understanding earnings quality: A review of the proxies, their determinants and their consequences. Journal of Accounting and Economics 50 (2-3): 344-401.

Deloitte Development LLC. 2013. Global business tax services. Available at: http://www.deloitte.com/view/en_US/us/Services/tax/global-business-tax/.

Deloitte LLP. 2013. Responsible tax: Sustainable tax strategy. Available at: http://www.deloitte.com/assets/DcomUnitedKingdom/Local\%20Assets/Documents/Services/Tax/uk-tax-responsible-taxv2.pdf.

Desai, M. and D. Dharmapala. 2006. Corporate tax avoidance and high-powered incentives. Journal of Financial Economics 79 (1): 145-179.

Dhaliwal, D., R. Gal-Or, V. Naiker, and D. Sharma. 2013. The influence of the audit committee of auditor provided tax planning services. Working paper, University of Arizona, Northeastern University, Monash University, and Kennesaw State University.

Diamond, D. W., and R. E. Verrecchia. 1982. Optimal managerial contracts and equilibrium security prices. Journal of Finance 37 (2):275-287.

Dickinson, V. 2011. Cash flow patterns as a proxy for firm life cycle. The Accounting Review 86 (6): 1969-1994.

Dooley, P. C. 1969. The interlocking directorate. American Economic Review 59 (3): 314-323.

Drake, K. 2013. Does firm life cycle explain the relation between book-tax differences and earnings persistence? Working paper, University of Arizona.

Duhigg, C., and D. Kocieniewski. 2012. How Apple sidesteps billions in taxes. The New York Times (April 28). 
Dyreng, S., Hanlon, M., and E. Maydew. 2008. Long-run corporate tax avoidance. The Accounting Review 83 (1): 61-82.

Dyreng, S., Hanlon, M., and E. Maydew. 2010. The effects of executives on corporate tax avoidance. The Accounting Review 85 (4): 1163-1189.

Ernst \& Young. 2013. Tax services. Available at: http://www.ey.com/GL/en/Services/Tax/About-our-global-tax-services.

Ferguson, A., J. Francis, and D. Stokes. 2003. The effects of firm-wide and office-level industry expertise on audit pricing. The Accounting Review 78 (2): 429-448.

Freeman, L. C. 1979. Centrality in social networks: conceptual clarification. Social Networks 1 (3): $215-239$.

Gardner, P. and D. Berry. 1995. The effect of different forms of advice on the control of a simulated complex system. Applied Cognitive Psychology 9 (7): 55-79.

Gibbons, A., J. Sniezek, and R. Dalal. 2003. Antecedents and consequences of unsolicited versus explicitly solicited advice. Presented at the annual meeting of the Society for Judgment and Decision Making, Vancouver, British Columbia.

Gino, F. 2008. Do we listen to advice just because we paid for it? The impact of cost of advice on its use. Organizational Behavior and Human Decision Processes 107 (2): 234-245.

Gort, M. and S. Klepper. 1982. Time paths in the diffusion of product innovation. Economic Journal 92 (367): 630-653.

Graham, J., M. Hanlon, T. Shevlin, and N. Shroff. 2013. Incentives for tax planning and avoidance: Evidence from the field. The Accounting Review, forthcoming.

Graham, J., C. Harvey, and S. Rajgopal. 2005. The economic implications of corporate financial reporting. Journal of Accounting and Economics 40 (1-3): 3-73.

Guay, W. 1999. The sensitivity of CEO wealth to equity risk: An analysis of the magnitude and determinants. Journal of Financial Economics 53 (1): 43-71.

Guenther, D., S. Matasunaga, and B. Williams. 2013. Tax avoidance, tax aggressiveness, tax risk, and firm risk. Working paper, University of Oregon.

Gulati, R., and J. Westphal. 1999. Cooperative or controlling? The effects of CEO-board relations and the content of interlocks on the formation of joint ventures. Administrative Science Quarterly 44 (3): 473-506.

Hambrick, D. 1981. Environment, strategy, and power within top management teams. Administrative Science Quarterly 26 (2): 253-275. 
Hambrick, B. 1983. Some tests of the effectiveness and functional attributes of Miles and Snow's strategic types. The Academy of Management Journal 26 (1): 5-26.

Hanlon, M. and S. Heitzman. 2010. A review of tax research. Journal of Accounting and Economics 50 (2-3): 127-178.

Hanlon, M. and J. Slemrod. 2009. What does tax aggressiveness signal? Evidence from stock price reactions to news about tax shelter involvement. Journal of Public Economics 93 (1-2): 126-141.

Hanlon, M., S. Laplante, and T. Shevlin. 2005. Evidence for the possible information loss of conforming book income and taxable income. Journal of Law and Economics 48 (2): 407-442.

Hanlon, M., L. Mills, and J. Slemrod. 2007. An empirical examination of big business tax noncompliance. In Taxing Corporate Income in the $21^{\text {st }}$ Century, edited by Auerbach, Hines, Jr., and Slemrod. Cambridge, U.K.: Cambridge University Press.

Harvey, N. and I. Fischer. 1997. Taking advice: Accepting help, improving judgment, and sharing responsibility. Organizational Behavior and Human Decision Processes 70 (2): 117-133.

Haunschild, P. R. 1993. Interorganizational imitation: the impact of interlocks on corporate acquisition activity. Administrative Science Quarterly 38 (4): 564-592.

Haythornthwaite, C. 1996. Social network analysis: An approach and technique for the study of information exchange. Library and Information Science Research 18 (4): 323-342.

Haythornthwaite, C. 2009. Social networks and information transfer. Encyclopedia of Library and Information Sciences 3 (1): 4837-4847.

Heckman, J. 1979. Sample selection bias as a specification error. Econometrica 47 (1): 153-161.

Higgins, D., T. Omer, and J. Phillips. 2014. The influence of a firm's business strategy on its tax aggressiveness. Contemporary Accounting Research, forthcoming.

Hölmstrom, B. 1979. Moral Hazard and Observability. The Bell Journal of Economics 10 (1):7491.

Horton, J., Y. Millo, and G. Serafim. 2012. Resources or power? Implications of social networks on compensation and firm performance. Journal of Business Finance \& Accounting 39 (3-4): 399-426.

Hosmer, D. and S. Lemeshow. 2002. Applied Logistic Regression. Wiley Series in Probability and Statistics. $2^{\text {nd }}$ ed. New York, NY: John Wiley \& Sons, Inc.

Inger, K. 2014. Relative valuation of alternative methods of tax avoidance. The Journal of the American Taxation Association 36 (1): 27-55. 
Ittner, C., D. Larcker, and M. Rajan. 1997. The choice of performance measures in annual bonus contracts. The Accounting Review 72 (2): 231-255.

Jensen, M. and W. Meckling. 1976. Theory of the firm: Managerial behavior, agency costs, and ownership structures. Journal of Financial Economics 3 (4): 305-360.

Jungermann, H. 1999. Advice-giving and taking. Presented at the $32^{\text {nd }}$ Hawaii International Conference on System Sciences for the Institute of Electrical and Electronics Engineers, Inc., Maui, HI.

Jungerman, H. and K. Fischer. 2005. Using expertise and experience for giving and taking advice. In The Routines of Decision Making, edited by Betsch and Haberstroh. Mahwah, NJ: Lawrence Erlbaum.

Kasznik, R. and M. McNichols. 2002. Does meeting earnings expectations matter? Evidence from analyst forecast revisions and share prices. Journal of Accounting Research 40 (3): 727-759.

Kocieniewski, D. 2011. G.E.'s strategies let it avoid taxes altogether. The New York Times (March 24).

Kothari, S., A. Leone, and C. Wasley. 2005. Performance matched discretionary accrual measures. Journal of Accounting and Economics 39 (1):163-197.

KPMG LLP. 2007. The governance of tax: A discussion paper. Available at: http://www.auditcommitteeinstitute.be/dbfetch/52616e646f6d4956ba3754dfd73bcc4c3fc79f032ab9d4a8/ www.bptawards.com.

Krause, J., C. Croft, and R. James. 2007. Social network theory in the behavioural sciences: Potential applications. Behavioral Ecology and Sociobiology 62 (1): 15-27.

Larcker, D., E. So, and C. Wang. 2013. Boardroom centrality and firm performance. Journal of Accounting and Economics 55 (2-3): 225-250.

Lassila, D., T. Omer, M. Shelley, and L. Smith. 2010. Do complexity, governance, and auditor independence influence whether firms retain their auditors for tax services? Journal of the American Taxation Association 32 (1): 1-23.

Mallar, C. 1977. The estimation of simultaneous probability models. Econometrica 45 (7): 17171722.

March, J. 1991. Exploration and exploitation in organizational learning. Organization Science 2 (1): 71-87.

Maydew, E. 1997. Tax-induced earnings management by firms with net operating losses. Journal of Accounting Research 35 (1): 83-96. 
McGuire, S., T. Omer, and D. Wang. 2012. Tax avoidance: Does tax-specific industry expertise make a difference? The Accounting Review 87 (3): 975-1003.

McGuire, S., S. Neuman, and T. Omer. 2013. Sustainable tax strategies and earnings persistence. Working paper, Texas A\&M University and University of Nebraska-Lincoln.

Miles, R. and C. Snow. 1978. Organizational Strategy, Structure and Process. New York, NY: McGraw-Hill.

Miles, R., C. Snow, A. Meyer, and J. Coleman, Jr. 1978. Organizational strategy, structure and process. The Academy of Management Review 3 (3): 546-562.

Miller, D. 1986. Configurations of strategy and structure: Towards a synthesis. Strategic Management Journal 7 (3): 233-249.

Miller, D. 1987. The structural and environmental correlates of business strategy. Strategic Management Journal 8 (1): 55-76.

Mills, L. 1998. Book-tax differences and Internal Revenue Service adjustments. Journal of Accounting Research 36 (2): 343-356.

Mills, L. and K. Newberry. 2001. The influence of tax and nontax costs on book-tax reporting differences: Public and private firms. The Journal of the American Taxation Association 23 (1): 1-19.

Mills, L. and R. Sansing. 2000. Strategic tax and financial reporting decisions: Theory and evidence. Contemporary Accounting Research 17 (1): 85-106.

Mills, L., M. Erickson, and E. Maydew. 1998. Investments in tax planning. The Journal of the American Taxation Association 20 (1): 1-20.

Minton, B. and C. Schrand. 1999. The impact of cash flow volatility on discretionary investment and the costs of debt and equity financing. Journal of Financial Economics 54 (3): 42360 .

Minton, B., C. Schrand, and B. Walther. 2002. The role of volatility on forecasting. Review of Accounting Studies 7 (2-3): 195-215.

Mintzberg, H. 1978. Patterns in strategy formation. Management Science 24 (9): 934-948.

Myers, L., J. Myers, and D. Skinner. 2007. Earnings momentum and earnings management. Journal of Accounting, Auditing, and Finance 22 (2): 249-284.

Neuman, S., T. Omer, and M. Shelley. 2013. Corporate transparency, sustainable tax strategies, and uncertain tax activities. Working paper, Texas A\&M University and University of Nebraska-Lincoln. 
Newman, M. 2010. Networks: An Introduction. New York, NY: Oxford University Press.

Omer, T., J. Bedard, and D. Falsetta. 2006. Auditor-provided tax services: The effects of a changing regulatory environment. The Accounting Review 81 (5): 1095-1117.

Omer, T., M. Shelley, and F. Tice. 2012. Do well-connected directors improve firm performance? Working paper, University of Nebraska-Lincoln and Texas A\&M University.

Omer, T., M. Shelley, and F. Tice. 2014. Do director networks matter for financial reporting? Evidence from restatements. Working paper, University of Nebraska-Lincoln and Texas A\&M University.

Palmer, D., R. Friedland, and J. Singh. 1986. The ties that bind: Organizational and class bases of stability in a corporate interlock network. American Sociological Review 51 (6): 781 796.

Palmer, D., P. D. Jennings, and X. Zhou. 1989. Growth strategies and institutional prescriptions: adoption of the multidivisional form by large U.S. corporations, 1963-1968. Presented at the annual meeting of the American Sociological Association, San Francisco, CA.

Paternoster, R., R. Brame, P. Mazerolle, and A. Piquero. 1998. Using the correct statistical test for the equality of regression coefficients. Criminology 36 (4): 859-866.

Pennings, J. 1980. Interlocking Directorates. San Francisco, CA: Josey-Bass Publishers.

Phelps, C, R. Hiedl, and A. Wadhwa. 2012. Knowledge, networks, and knowledge networks: A review and research agenda. Journal of Management 38 (4): 1115-1166.

Phillips, J. 2003. Corporate tax-planning effectiveness: The role of compensation-based incentives. The Accounting Review 78 (3): 847-874.

Popelka, L. 2013. More companies needs high-priced CEOs. Bloomberg Business Week (April $3)$.

Porter, M. 2004. Competitive Strategy: Techniques for Analyzing Industries and Competitors. New York, NY: Free Press.

Powers, K., J. Robinson, and B. Stomberg. 2013. Do CEO performance measures motivate tax avoidance? Working paper, University of Texas at Austin and University of Georgia.

PricewaterhouseCoopers. 2013. Substance 2.0: Aligning international tax planning with today's business realities. Available at: http://www.pwc.com/gx/en/tax/publications/substance-2aligning-international-tax-planning-with-todays-business-realities.jhtml.

PricewaterhouseCoopers LLP (PwC). 2008. Integrating global structuring: Aligning global business models and tax planning. Available at: 
http://www.pwc.com/en_US/us/issues/integrated-globalstructuring/assets/integrated_global_structuring.pdf.

Public Accounting Report. 2008. Tax practices lead growth for national survey firms: KPMG paces Big Four in A\&A growth rate: E\&Y leads Big Four in tax growth. 32 (April 30): 8.

Rego, S. and R. Wilson. 2012. Equity risk incentives and corporate tax aggressiveness. Journal of Accounting Research 50 (3): 775-810.

Robinson, J., S. Sikes, and C. Weaver. 2010. Performance measurement of corporate tax departments. The Accounting Review 85 (3): 1035-1064.

Robinson, J., Y. Xue, and M. Zhang. 2012. Tax planning and financial expertise in the audit committee. Working paper, University of Texas at Austin, George Washington University, and Fordham University.

Rountree, B., J. Weston, and G. Allayannis. 2008. Do investors value smooth performance? Journal of Financial Economics 90 (3): 237-251.

Schmidt, A. 2006. The persistence, forecasting, and valuation implications of the tax change component of earnings. The Accounting Review 81 (3): 589-616.

Scholes, M., M. Wolfson, M. Erikson, E. Maydew, and T. Shevlin. 2009. Taxes and Business Strategy: A Planning Approach. $4^{\text {th }}$ ed. Upper Saddle River, NJ: Pearson Prentice Hall.

Schumpeter, J. 2012. Corporate tax avoidance: The price isn't right. The Economist (September 21).

Scott, J. 1991. Networks of corporate power: a comparative assessment. Annual Review of Sociology 17 (1): $181-203$.

SD Mayer \& Associates LLP. 2013. Services: Tax. Available at: http://sdmayer.com/services/tax/.

Shackelford, D., and T. Shevlin. 2001. Empirical tax research in accounting. Journal of Accounting and Economics 31 (1-3): 321-387.

Shapiro, C. 1989. The theory of business strategy. The RAND Journal of Economics 20 (1): 125137.

Shevlin, T. 2007. The future of tax research: From an accounting professor's perspective. The Journal of the American Taxation Association 29 (2): 87-93.

Slemrod, J. 2004. The economics of corporate tax selfishness. National Tax Journal 57 (4): 877899. 
Smith, C. and R. Stulz. 1985. The determinants of firms' hedging policies. Journal of Financial and Quantitative Analysis 20 (4): 391-405.

Sniezek, J., G. Schrah, and R. Dalal. 2004. Improving judgment with prepaid expert advice. Journal of Behavioral Decision Making 17 (3): 173-190.

Solomon, I., M. Shields, and O. Whittington. 1999. What do industry-specialist auditors know? Journal of Accounting Research 37 (1): 191-208.

Strategic Capital Partners, LLC. 2012. Tax strategies. Available at: http://www.scpibank.com/Strategic_Capital_Partners/Tax_Strategies.html.

Tax Executives Institute (TEI). 2005. 2004-2005 corporate tax department survey. The Tax Executive Institute 64 (1): 1-184.

Tucker, J. 2007. Is openness penalized? Stock returns around earnings warnings. The Accounting Review 82 (4): 1055-1087.

Wasserman, S. and K. Faust. 1994. Social Network Analysis: Methods and Applications. Cambridge, UK: Cambridge University Press.

Wellman, B. and S. Berkowitz. 1988. Social Structures: A Network Approach. Greenwich, CT: JAI Press.

Woolridge, J. 2010. Econometric Analysis of Cross Section and Panel Data. $2^{\text {nd }}$ ed. Cambridge, MA: The MIT Press.

Yaniv, I. 2004a. The benefit of additional opinions. Current Directions in Psychological Science 13 (2): 75-78.

Yaniv, I. 2004b. Receiving other people's advice: Influence and benefit. Organizational Behavior and Human Decision Processes 93 (1): 1-13.

Yaniv, I. and E. Kleinberger. 2000. Advice taking in decision making: Egocentric discounting and reputation formation. Organizational Behavior and Human Decision Processes 83 (2): $260-281$.

Yaniv, I. and M. Mailyavsy. 2007. Using advice from multiple sources to revise and improve judgment. Organizational Behavior and Human Decision Processes 103 (1):104-120.

Zahra, S. and J. Covin. 1993. Business strategy, technology policy and firm performance. Strategic Management Journal 14 (6): 451-478.

Zeff, S. 2003. How the U.S. accounting profession got where it is today: Part I. Accounting Horizons 17 (3): 189-206. 


\section{APPENDIX A}

\section{EXAMPLES OF FIRMS WITH SUSTAINABLE AND MINIMIZATION TAX}

STRATEGIES

APPENDIX TABLE 1A

Examples of Firms with Sustainable and Minimization Tax Strategies

\begin{tabular}{|c|c|c|c|c|}
\hline \multirow[t]{3}{*}{ Variables } & \multicolumn{2}{|c|}{ SUSTAIN } & \multicolumn{2}{|c|}{ MINIMIZE } \\
\hline & \multicolumn{2}{|c|}{ The Coca-Cola Company } & \multicolumn{2}{|c|}{ PeopleSoft, Inc. } \\
\hline & Mean & Median & Mean & Median \\
\hline CV_CETR & 0.124 & 0.098 & 0.793 & 0.881 \\
\hline CETR3 & 0.233 & 0.232 & 0.099 & 0.094 \\
\hline CETR RANGE & 0.051 & 0.047 & 0.324 & 0.351 \\
\hline$R O A$ & 0.156 & 0.162 & 0.059 & 0.068 \\
\hline \multirow[t]{3}{*}{$C V \_P T B I$} & 0.106 & 0.096 & 0.456 & 0.451 \\
\hline & \multicolumn{2}{|c|}{ Kimberly-Clark Corp. } & \multicolumn{2}{|c|}{ Eli Lilly \& Co. } \\
\hline & Mean & Median & Mean & Median \\
\hline CV_CETR & 0.196 & 0.214 & 0.611 & 0.577 \\
\hline CETR3 & 0.239 & 0.244 & 0.161 & 0.134 \\
\hline CETR RANGE & 0.075 & 0.069 & 0.178 & 0.186 \\
\hline$R O A$ & 0.099 & 0.101 & 0.121 & 0.126 \\
\hline$C V \_P T B I$ & 0.066 & 0.050 & 0.130 & 0.123 \\
\hline \multicolumn{5}{|c|}{$\begin{array}{l}\text { Means and medians are calculated at the firm-level using all available observations over the sample period. CV_CETR } \\
\text { measures the variability of annual cash ETRs. CETR3 is the firm's three-year cash ETR. CETR RANGE is the } \\
\text { difference between the highest and lowest annual cash ETRs within the three-year cash ETR (CETR3). ROA is the } \\
\text { firm's return-on-assets, and } C V \_P T B I \text { measures the firm's earnings volatility. }\end{array}$} \\
\hline
\end{tabular}

To illustrate the differences in sustainable and minimization tax strategies, Table 1A presents additional descriptive statistics for firms identified as following either a sustainable or minimization tax strategy. The mean and median CV_CETR (CETR3) for Coca-Cola and Kimberly-Clark (sustainers) are much lower (higher) than those of PeopleSoft and Eli Lilly (minimizers), consistent with the definitions of sustainable (minimization) tax strategies. All four firms are profitable $(R O A>=0.06)$, which implies that each firm likely has a valuemaximizing tax strategy. However, Coca-Cola's and Kimberly-Clark's earnings volatility $\left(C V \_P T B I\right)$ is lower when compared to PeopleSoft and Eli Lilly, consistent with prior literature 
that finds that firms with sustainable tax strategies have more persistent and less volatile earnings (McGuire et al. 2013). Finally, CETR RANGE, the difference between the highest and lowest annual cash ETR within CETR3, is smaller for Coca-Cola and Kimberly-Clark, relative to PeopleSoft and Eli Lilly, consistent with firms focusing on sustainability reporting low year-toyear variability in tax outcomes (Deloitte 2013; KPMG LLP 2007; PwC 2008) while firms emphasizing minimization are less concerned about the risk and/or variability of any tax activity's expected outcome. 


\section{APPENDIX B}

\section{VARIABLE DEFINITIONS}

\begin{tabular}{|c|c|}
\hline Variable & Definition \\
\hline \multicolumn{2}{|c|}{ Tax Strategies } \\
\hline SUSTAIN & $\begin{aligned}= & \text { An indicator variable equal to one if the firm-year observation has a } \\
& \text { coefficient of variation of cash ETRs }\left(C V_{-} C E T R\right) \text { in the lowest quintile for } \\
& \text { the year and equal to zero otherwise. }\end{aligned}$ \\
\hline MINIMIZE & $\begin{array}{l}=\text { An indicator variable equal to one if the firm-year observation has a three- } \\
\text { year cash ETR (CETR3) less than or equal to } 20 \text { percent and equal to zero } \\
\text { otherwise. }\end{array}$ \\
\hline MIXED & $\begin{aligned}= & \text { An indicator variable equal to one if both SUSTAIN and MINIMIZE equal } \\
& \text { zero for the firm-year observation and equal to zero otherwise. }\end{aligned}$ \\
\hline CV_CETR & $\begin{aligned}= & \text { The standard deviation of annual cash ETRs for the five-year period prior } \\
& \text { to and including the current year }(t \text { to } t-4) \text { scaled by the absolute value of } \\
& \text { the mean of annual cash ETRs over the same five-year period. }\end{aligned}$ \\
\hline CETR3 & $\begin{array}{l}=\text { The ratio of the sum of cash taxes paid }(T X P D) \text { divided by the sum of pre- } \\
\text { tax book income less special items }(P I-S P I) \text { measured over the three-year } \\
\text { period, } t \text { to } t-2 \text {. }\end{array}$ \\
\hline
\end{tabular}

Managerial Incentives/Practices

DELTA = The change in the CEO's wealth for a one percent change in the firm's stock price, following Core and Guay (1999).

$V E G A=$ The change in value of the CEO's stock option portfolio for a one percent change in stock return volatility, following Core (1999).

TAXEXPERT $=$ An indicator variable equal to one if the audit firm has a tax service market share equal to 30 percent ( 25 percent) or more in years 2003 or later (2002 and earlier) within a Metropolitan Statistical Area (MSA) and industry and equal to zero otherwise, following McGuire et al. (2012).

$I N F O=$ The factor score of a vector of four director centrality (connectivity)

TRANSFER measures, NUM_CONNECTIONS, CONTROL, SPEED, and CONNECTION_STRENGTH. NUM_CONNECTIONS is the number of unique connections a director has with other directors in the network. CONTROL is calculated as the number of paths between two individuals in the network, $a$ and $b$, that pass through individual $i$ divided by the total number of paths between the two individuals, $a$ and $b$. SPEED is the inverse of the sum of the shortest distances of the paths between the director and the other directors in the network.

CONNECTION_STRENGTH is measured as the number of unique connections a director has with other directors, but weights each of these connections based upon how well-connected those directors are within the network. 


\section{VARIABLE DEFINITIONS (continued)}

Variable Definition

\section{Tax Planning}

SIZE $\quad=$ The natural logarithm of sales $(S A L E)$ plus one.

LEVERAGE $=$ The ratio of total long-term debt $(D L T T)$ to end-of-the-year total assets $(A T)$.

$P P E \quad=$ The ratio of property, plant, and equipment $(P P E)$ to end-of-the-year total assets $(A T)$.

$F O R \_O P=$ An indicator variable equal to one if foreign income $(P I F O)$ is greater than zero and equal to zero otherwise.

$T L C F=$ An indicator variable equal to one if tax loss carryforward $(T L C F)$ is greater than zero and equal to zero otherwise.

$S E G M E N T S=$ The sum of the number of business $(B U S S E G)$ and operating $(O P S E G)$ segments reported during the year.

\section{Performance}

$C V \_P T B I=$ The standard deviation of annual pre-tax book income (PI-SPI) for the fiveyear period prior to and including the current year ( $t$ to $t-4)$ scaled by the absolute value of the mean of annual pre-tax book income over the same fiveyear period.

$R O A=$ The ratio of income before extraordinary items $(I B)$ to average total assets $(A T)$.

$B T M=$ The ratio of total common equity $(C E Q)$ to market value of equity $($ PRCC_F*CSHO).

\section{Investing/Reporting}

$R D=$ The ratio of research and development expense $(X R D)$ to beginning-of-theyear total assets $(A T)$.

$D I S C_{-} A C C=$ The signed value of the error term from the regression of total accruals $\left(\left(I B_{t^{-}}\right.\right.$ $\left.\left.O A N C F_{t}\right) / A T_{t-1}\right)$ on the inverse of beginning-of-the-year total assets $\left(1 / A T_{t-1}\right)$, the change in sales adjusted for the change in receivables $\left(\left(\left(S A L E_{t}-S A L E_{t-1}\right)-\right.\right.$ $\left.\left.\left(R E C T_{t}-R E C T_{t-1}\right)\right) / A T_{t-1}\right)$, current year property, plant, and equipment $\left(P P E N T_{t} / A T_{t-1}\right)$, and prior year return on assets, all scaled by beginning of the year total assets $\left(\left(N I_{t-1} / A T_{t-2}\right) / A T_{t-1}\right)$, calculated using the modified Jones (1991) model as modified by Kothari et al. (2005).

IMR = The inverse Mills ratio calculated from coefficient estimates from model (3). 


\section{VARIABLE DEFINITIONS (continued)}

Variable Definition

\begin{tabular}{|c|c|}
\hline TAXSERVICE & $\begin{array}{l}=\text { An indicator variable equal to one if the client purchased tax services } \\
\text { from their external audit firm and equal to zero otherwise. }\end{array}$ \\
\hline TENURE & $=$ The length of the audit firm's tenure with the client. \\
\hline INSTOWN & $\begin{array}{l}=\text { The percentage of common shares outstanding owned by institutions at } \\
\text { the beginning of the year. }\end{array}$ \\
\hline MERGER & $\begin{aligned}= & \text { An indicator variable equal to one if the firm engaged in any merger or } \\
& \text { acquisition activity ( } A Q P \text { not equal to missing) during the year and equal } \\
& \text { to zero otherwise. }\end{aligned}$ \\
\hline$A U D I N D$ & $\begin{array}{l}=\text { The auditor's independence from the client calculated as non-audit fees } \\
\text { less tax service fees received from the client scaled by total audit fees } \\
\text { received from the client. }\end{array}$ \\
\hline \multicolumn{2}{|c|}{ LNAUDITFEES = The natural logarithm of audit fees received from the client. } \\
\hline OPPORTUNIT & $\begin{array}{l}=\text { The market value of the client scaled by the sum of the market values of } \\
\text { all clients in the same Metropolitan Statistical Area (MSA) and industry. }\end{array}$ \\
\hline$\triangle T L C F$ & $\begin{aligned}= & \text { The change in the value of the tax loss carryforward }(T L C F) \text { from year } t \text { - } \\
& 1 \text { to year } t \text { scaled by beginning-of-the-year total assets }(A T) \text {. }\end{aligned}$ \\
\hline EQINC & $\begin{array}{l}=\text { The equity income of the client }(E S U B) \text { scaled by beginning-of-the-year } \\
\text { total assets }(A T) \text {. }\end{array}$ \\
\hline CASH & $\begin{array}{l}=\text { The cash and cash equivalents }(C H E) \text { scaled by beginning-of-the-year } \\
\text { total assets }(A T) \text {. }\end{array}$ \\
\hline DEP & $\begin{array}{l}=\text { The depreciation and amortization expense }(D P) \text { scaled by beginning-of- } \\
\text { the-year total assets }(A T) \text {. }\end{array}$ \\
\hline BIG4 & $\begin{aligned}= & \text { An indicator variable equal to one if the client is audited by a Big } 4 \\
& \text { accounting firm and equal to zero otherwise. }\end{aligned}$ \\
\hline SECTIER & $\begin{aligned}= & \text { An indicator variable equal to one if the client is audited by either Grant } \\
& \text { Thornton or BDO Seidman and equal to zero otherwise. }\end{aligned}$ \\
\hline
\end{tabular}




\section{APPENDIX C}

\section{TABLES}

TABLE 1

Descriptive Statistics

\section{Panel A: Descriptive Statistics for Full Sample}

\begin{tabular}{|c|c|c|c|c|c|c|c|c|}
\hline Variable & $\mathbf{N}$ & Mean & Std Dev & $25 \%$ & Median & $75 \%$ & Minimum & Maximum \\
\hline \multicolumn{9}{|l|}{ Tax Strategies } \\
\hline SUSTAIN & 4668 & 0.327 & 0.469 & 0 & 0 & 1 & 0 & 1 \\
\hline MINIMIZE & 4668 & 0.356 & 0.479 & 0 & 0 & 1 & 0 & 1 \\
\hline CV_CETR & 4668 & 0.584 & 0.439 & 0.251 & 0.456 & 0.805 & 0.063 & 2.175 \\
\hline CETR3 & 4668 & 0.246 & 0.144 & 0.156 & 0.244 & 0.321 & 0 & 1 \\
\hline \multicolumn{9}{|c|}{ Managerial Incentives/Practices } \\
\hline$\overline{D E L T A}$ & 4668 & 654.948 & 1684.490 & 56.333 & 164.265 & 484.487 & 0.237 & 12496.130 \\
\hline$V E G A$ & 4668 & 106.356 & 236.986 & 0 & 0 & 94.084 & 0 & 1374.020 \\
\hline TAXEXPERT & 4668 & 0.568 & 0.495 & 0 & 1 & 1 & 0 & 1 \\
\hline INFO & 4668 & 0.000 & 1.000 & -0.716 & -0.239 & 0.526 & -1.593 & 4.249 \\
\hline TRANSFER & & & & & & & & \\
\hline \multicolumn{9}{|l|}{ Tax Planning } \\
\hline$\overline{S I Z E}$ & 4668 & 7.796 & 1.444 & 6.764 & 7.623 & 8.694 & 4.725 & 11.495 \\
\hline LEVERAGE & 4668 & 0.172 & 0.140 & 0.041 & 0.160 & 0.265 & 0 & 0.578 \\
\hline$P P E$ & 4668 & 0.257 & 0.200 & 0.108 & 0.196 & 0.349 & 0.021 & 0.866 \\
\hline$F O R \_O P$ & 4668 & 0.136 & 0.343 & 0 & 0 & 0 & 0 & 1 \\
\hline$T L C F$ & 4668 & 0.472 & 0.499 & 0 & 0 & 1 & 0 & 1 \\
\hline SEGMENTS & 4668 & 3.542 & 2.400 & 1 & 3 & 5 & 1 & 21 \\
\hline \multicolumn{9}{|l|}{ Performance } \\
\hline$\overline{C V \_P T B I}$ & 4668 & 0.562 & 0.892 & 0.187 & 0.329 & 0.566 & 0.050 & 6.850 \\
\hline$R O \bar{A}$ & 4668 & 0.071 & 0.061 & 0.036 & 0.066 & 0.102 & -0.140 & 0.275 \\
\hline BTM & 4668 & 0.465 & 0.299 & 0.257 & 0.401 & 0.597 & -0.015 & 1.679 \\
\hline \multicolumn{9}{|c|}{ Investing/Reporting } \\
\hline$R D$ & 4668 & 0.030 & 0.047 & 0 & 0.006 & 0.041 & 0 & 0.215 \\
\hline$D I S C \_A C C$ & 4668 & 0.052 & 0.093 & -0.003 & 0.044 & 0.106 & -0.220 & 0.327 \\
\hline$I M R$ & 4668 & 0.376 & 0.109 & 0.311 & 0.338 & 0.388 & 0.288 & 0.798 \\
\hline
\end{tabular}


TABLE 1 (continued)

\begin{tabular}{|c|c|c|c|c|c|c|c|c|c|c|c|c|c|c|c|}
\hline \multirow[b]{2}{*}{ Variable } & \multicolumn{5}{|c|}{$\begin{array}{c}\text { Panel B: Descriptive Statistics by Tax Strategy - } \\
\text { SUSTAIN } \\
(1,526 \text { observations })\end{array}$} & \multicolumn{5}{|c|}{$\begin{array}{c}\text { Panel C: Descriptive Statistics by Tax Strategy - } \\
\text { MIXED } \\
(1,667 \text { observations })\end{array}$} & \multicolumn{5}{|c|}{$\begin{array}{c}\text { Panel D: Descriptive Statistics by Tax Strategy - } \\
\text { MINIMIZE } \\
(1,662 \text { observations })\end{array}$} \\
\hline & Mean & Std Dev & $25 \%$ & Median & $75 \%$ & Mean & Std Dev & $25 \%$ & Median & $75 \%$ & Mean & Std Dev & $25 \%$ & Median & $75 \%$ \\
\hline \multicolumn{16}{|l|}{ Tax Strategies } \\
\hline CV_CETR & 0.19 & 0.07 & 0.14 & 0.19 & 0.25 & 0.63 & 0.29 & 0.40 & 0.56 & 0.79 & 0.86 & 0.50 & 0.46 & 0.75 & 1.16 \\
\hline CETR3 & 0.29 & 0.08 & 0.24 & 0.29 & 0.34 & 0.33 & 0.15 & 0.24 & 0.29 & 0.37 & 0.11 & 0.06 & 0.06 & 0.12 & 0.16 \\
\hline \multicolumn{16}{|c|}{ Managerial Incentives/Practices } \\
\hline DELTA & 872.67 & 2066.32 & 74.55 & 210.36 & 660.71 & 488.52 & 1355.51 & 43.81 & 126.24 & 368.39 & 674.55 & 1665.16 & 61.96 & 185.24 & 546.37 \\
\hline$V E G A$ & 124.13 & 262.40 & 0 & 0 & 119.64 & 81.99 & 202.71 & 0 & 0 & 65.73 & 125.17 & 259.88 & 0 & 0 & 121.26 \\
\hline TAXEXPERT & 0.60 & 0.49 & 0 & 1 & 1 & 0.54 & 0.50 & 0 & 1 & 1 & 0.58 & 0.49 & 0 & 1 & 1 \\
\hline $\begin{array}{l}\text { INFO } \\
\text { TRANSFER }\end{array}$ & 0.17 & 1.03 & -0.61 & -0.03 & 0.76 & -0.09 & 0.99 & -0.79 & -0.29 & 0.37 & -0.02 & 1.00 & -0.74 & -0.27 & 0.52 \\
\hline \multicolumn{16}{|l|}{$\underline{\text { Tax Planning }}$} \\
\hline SIZE & 8.26 & 1.43 & 7.22 & 8.18 & 9.21 & 7.66 & 1.37 & 6.65 & 7.49 & 8.54 & 7.60 & 1.46 & 6.60 & 7.47 & 8.48 \\
\hline LEVERAGE & 0.17 & 0.13 & 0.06 & 0.16 & 0.25 & 0.17 & 0.14 & 0.04 & 0.16 & 0.27 & 0.18 & 0.15 & 0.03 & 0.16 & 0.28 \\
\hline$P P E$ & 0.26 & 0.18 & 0.13 & 0.21 & 0.34 & 0.25 & 0.19 & 0.11 & 0.21 & 0.35 & 0.26 & 0.23 & 0.09 & 0.18 & 0.37 \\
\hline FOR_OP & 0.14 & 0.35 & 0 & 0 & 0 & 0.13 & 0.33 & 0 & 0 & 0 & 0.15 & 0.36 & 0 & 0 & 0 \\
\hline$T L C F$ & 0.41 & 0.49 & 0 & 0 & 1 & 0.48 & 0.50 & 0 & 0 & 1 & 0.52 & 0.50 & 0 & 1 & 1 \\
\hline SEGMENTS & 3.65 & 2.33 & 1 & 3 & 5 & 3.63 & 2.53 & 1 & 3 & 5 & 3.44 & 2.34 & 1 & 3 & 5 \\
\hline \multicolumn{16}{|l|}{ Performance } \\
\hline CV_PTBI & 0.24 & 0.15 & 0.14 & 0.21 & 0.32 & 0.56 & 0.76 & 0.23 & 0.38 & 0.60 & 0.82 & 1.22 & 0.24 & 0.43 & 0.78 \\
\hline ROA & 0.09 & 0.05 & 0.06 & 0.09 & 0.12 & 0.06 & 0.06 & 0.03 & 0.06 & 0.09 & 0.07 & 0.06 & 0.03 & 0.06 & 0.09 \\
\hline BTM & 0.39 & 0.25 & 0.22 & 0.34 & 0.51 & 0.52 & 0.32 & 0.31 & 0.46 & 0.66 & 0.47 & 0.30 & 0.25 & 0.41 & 0.61 \\
\hline \multicolumn{16}{|c|}{ Investing/Reporting } \\
\hline$R D$ & 0.02 & 0.03 & 0 & 0.00 & 0.03 & 0.03 & 0.05 & 0 & 0.00 & 0.04 & 0.04 & 0.06 & 0 & 0.02 & 0.07 \\
\hline DISC_ACC & 0.06 & 0.09 & 0.00 & 0.04 & 0.10 & 0.05 & 0.10 & -0.01 & 0.05 & 0.11 & 0.05 & 0.10 & 0.00 & 0.05 & 0.11 \\
\hline$I M R$ & 0.36 & 0.10 & 0.31 & 0.33 & 0.37 & 0.39 & 0.11 & 0.32 & 0.35 & 0.40 & 0.37 & 0.11 & 0.31 & 0.33 & 0.39 \\
\hline
\end{tabular}

Refer to Appendix B for variable definitions.

All variables except SUSTAIN, MINIMIZE, MIXED, CETR3, TAXEXPERT, FOR_OP, TLCF, SEGMENTS, and IMR have been winsorized at the $1^{\text {st }}$ and $99^{\text {th }}$ percentiles. 
TABLE 2

\begin{tabular}{|c|c|c|c|c|c|c|c|c|c|c|c|c|c|c|c|c|c|c|c|c|}
\hline \multicolumn{21}{|c|}{ Correlations } \\
\hline & (1) & (2) & (3) & (4) & (5) & (6) & (7) & $(8)$ & (9) & $(10)$ & (11) & (12) & (13) & (14) & (15) & (16) & (17) & (18) & (19) & $(20)$ \\
\hline \multicolumn{21}{|l|}{$\underline{\text { Tax Strategies }}$} \\
\hline (1) SUSTAIN & 1 & & & & & & & & & & & & & & & & & & & \\
\hline (2) MINIMIZE & -0.34 & 1 & & & & & & & & & & & & & & & & & & \\
\hline (3) $\boldsymbol{C} V_{-} C E T R$ & -0.62 & 0.46 & 1 & & & & & & & & & & & & & & & & & \\
\hline (4) $C E T R 3$ & 0.20 & -0.70 & -0.35 & 1 & & & & & & & & & & & & & & & & \\
\hline \multicolumn{21}{|c|}{$\begin{array}{l}\text { Managerial } \\
\text { Incentives/Practices }\end{array}$} \\
\hline (5) DELTA & 0.09 & 0.01 & -0.08 & -0.01 & 1 & & & & & & & & & & & & & & & \\
\hline (6) $\boldsymbol{V E G A}$ & 0.05 & 0.06 & -0.03 & -0.05 & 0.26 & 1 & & & & & & & & & & & & & & \\
\hline (7) $T A X E X P E R T$ & 0.05 & 0.02 & -0.04 & -0.00 & 0.04 & -0.04 & 1 & & & & & & & & & & & & & \\
\hline $\begin{array}{l}\text { (8) INFO } \\
\text { TRANSFER }\end{array}$ & 0.12 & -0.02 & -0.13 & 0.01 & 0.11 & 0.40 & 0.05 & 1 & & & & & & & & & & & & \\
\hline \multicolumn{21}{|l|}{$\underline{\text { Tax Planning }}$} \\
\hline (9) $S I Z E$ & 0.22 & -0.10 & -0.28 & 0.07 & 0.23 & 0.28 & 0.18 & 0.55 & 1 & & & & & & & & & & & \\
\hline (10) LEVERAGE & -0.03 & 0.03 & 0.03 & -0.05 & -0.04 & 0.03 & 0.01 & 0.16 & 0.17 & 1 & & & & & & & & & & \\
\hline (11) $P P E$ & -0.01 & 0.02 & 0.02 & -0.02 & 0.01 & 0.02 & -0.04 & 0.07 & 0.11 & 0.25 & 1 & & & & & & & & & \\
\hline (12) $\mathbf{F O R} \_\mathbf{O P}$ & 0.01 & 0.03 & -0.03 & -0.02 & 0.05 & 0.18 & -0.13 & 0.10 & 0.06 & 0.06 & -0.01 & 1 & & & & & & & & \\
\hline (13) $\boldsymbol{T} \boldsymbol{L} \boldsymbol{C} \boldsymbol{F}$ & -0.09 & 0.07 & 0.10 & -0.09 & -0.04 & -0.06 & 0.04 & -0.05 & 0.00 & 0.07 & -0.14 & 0.00 & 1 & & & & & & & \\
\hline (14) SEGMENTS & 0.03 & -0.03 & -0.06 & 0.05 & 0.03 & 0.10 & 0.06 & 0.27 & 0.29 & 0.13 & -0.03 & 0.12 & 0.09 & 1 & & & & & & \\
\hline \multicolumn{21}{|l|}{ Performance } \\
\hline$\overline{(15) C_{C} P T B I}$ & -0.25 & 0.21 & 0.51 & -0.13 & -0.03 & -0.03 & 0.00 & -0.12 & -0.22 & -0.02 & 0.00 & -0.02 & 0.05 & -0.06 & 1 & & & & & \\
\hline (16) $\mathrm{ROA}$ & 0.25 & -0.07 & -0.24 & -0.02 & 0.09 & 0.08 & 0.03 & 0.02 & 0.04 & -0.26 & -0.03 & -0.03 & -0.12 & -0.08 & -0.10 & 1 & & & & \\
\hline (17) BTM & -0.18 & 0.01 & 0.16 & 0.06 & -0.15 & -0.20 & -0.07 & -0.18 & -0.09 & 0.03 & 0.08 & -0.03 & 0.06 & 0.02 & 0.09 & -0.49 & 1 & & & \\
\hline \multicolumn{21}{|l|}{ Investing/Reporting } \\
\hline (18) $R D$ & -0.16 & 0.22 & 0.21 & -0.19 & 0.03 & 0.08 & -0.02 & -0.09 & -0.22 & -0.25 & -0.31 & -0.01 & 0.07 & -0.12 & 0.18 & 0.12 & -0.21 & 1 & & \\
\hline (19) DISC_ACC & 0.02 & 0.01 & -0.02 & 0.01 & -0.02 & 0.03 & -0.02 & 0.04 & -0.03 & -0.01 & -0.11 & 0.06 & 0.05 & 0.05 & 0.02 & 0.22 & -0.08 & 0.15 & 1 & \\
\hline (20) $I M R$ & -0.08 & -0.02 & 0.06 & 0.05 & -0.01 & 0.04 & -0.41 & -0.13 & -0.25 & 0.01 & 0.13 & 0.19 & -0.13 & -0.10 & 0.06 & -0.04 & 0.13 & -0.05 & -0.06 & 1 \\
\hline $\begin{array}{l}\text { All coefficients in } \\
\text { Refer to Appendix }\end{array}$ & $\begin{array}{l}\text { signif } \\
\text { ariable } \\
A I N, N\end{array}$ & $\begin{array}{l}\text { cant at } \\
\text { definiti }\end{array}$ & east th & $\begin{array}{l}5 \% \text { sign } \\
\text { CETR3 }\end{array}$ & icance & $\begin{array}{l}\text { evel. } \\
E R T \text {, }\end{array}$ & $O P$ & . & $M E I$ & and & 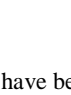 & 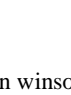 & ed & 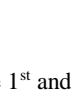 & & tiles. & & & & \\
\hline
\end{tabular}


TABLE 3

Equity Incentives - Seemingly Unrelated Bivariate Probit Regression

\begin{tabular}{|c|c|c|c|c|}
\hline VARIABLES & $\begin{array}{c}(1) \\
\text { SUSTAIN }\end{array}$ & $\begin{array}{c}(2) \\
M I N I M I Z E\end{array}$ & $\begin{array}{c}\text { (3) } \\
\text { SUSTAIN }\end{array}$ & $\begin{array}{c}\text { (4) } \\
M I N I M I Z E\end{array}$ \\
\hline & & & $\begin{array}{l}\text { Marginal } \\
\text { Effects }\end{array}$ & $\begin{array}{l}\text { Marginal } \\
\text { Effects }\end{array}$ \\
\hline \multicolumn{5}{|c|}{ Managerial Incentives/Practices } \\
\hline DELTA & $\begin{array}{l}0.000048 \\
3.281 * * *\end{array}$ & $\begin{array}{c}0.000004 \\
0.270\end{array}$ & $\begin{array}{l}0.000009 \\
2.900 * * *\end{array}$ & $\begin{array}{c}-0.000002 \\
-0.57\end{array}$ \\
\hline$V E G A$ & $\begin{array}{c}-0.000135 \\
-1.347\end{array}$ & $\begin{array}{l}0.000353 \\
3.857 * * *\end{array}$ & $\begin{array}{c}-0.000053 \\
-2.41 * * *\end{array}$ & $\begin{array}{c}0.000097 \\
3.88 * * *\end{array}$ \\
\hline \multicolumn{5}{|l|}{ Tax Planning } \\
\hline SIZE & $\begin{array}{l}0.125707 \\
6.254 * * *\end{array}$ & $\begin{array}{c}-0.021287 \\
-1.195\end{array}$ & $\begin{array}{l}0.026248 \\
6.14 * * * *\end{array}$ & $\begin{array}{l}-0.012998 \\
-2.69 * * *\end{array}$ \\
\hline LEVERAGE & $\begin{array}{l}-0.543732 \\
-2.755^{* * *}\end{array}$ & $\begin{array}{l}0.464511 \\
2.722 * * *\end{array}$ & $\begin{array}{l}-0.141229 \\
-3.37 * * *\end{array}$ & $\begin{array}{c}0.149398 \\
3.22 * * *\end{array}$ \\
\hline$P P E$ & $\begin{array}{c}-0.351761 \\
-1.847^{*}\end{array}$ & $\begin{array}{l}0.565438 \\
3.380 * * *\end{array}$ & $\begin{array}{l}-0.111067 \\
-2.72 * * *\end{array}$ & $\begin{array}{c}0.162933 \\
3.58 * * *\end{array}$ \\
\hline FOR_OP & $\begin{array}{c}-0.070417 \\
-1.058\end{array}$ & $\begin{array}{c}0.049359 \\
0.830\end{array}$ & $\begin{array}{c}-0.017329 \\
-1.23\end{array}$ & $\begin{array}{c}0.016792 \\
1.01\end{array}$ \\
\hline$T L C F$ & $\begin{array}{l}-0.150085 \\
-3.200 * * *\end{array}$ & $\begin{array}{l}0.116323 \\
2.790 * * *\end{array}$ & $\begin{array}{l}-0.038148 \\
-3.88 * * *\end{array}$ & $\begin{array}{c}0.038440 \\
3.28 * * *\end{array}$ \\
\hline SEGMENTS & $\begin{array}{c}0.000754 \\
0.070\end{array}$ & $\begin{array}{c}-0.005026 \\
-0.527\end{array}$ & $\begin{array}{c}0.000522 \\
0.22\end{array}$ & $\begin{array}{c}-0.001304 \\
-0.50\end{array}$ \\
\hline \multicolumn{5}{|l|}{ Performance } \\
\hline$C V \_P T B I$ & $\begin{array}{c}-2.547150 \\
-19.610^{* * *}\end{array}$ & $\begin{array}{l}0.242495 \\
9.066 * * *\end{array}$ & $\begin{array}{l}-0.517806 \\
-24.83 * * *\end{array}$ & $\begin{array}{l}0.216115 \\
19.11 * * *\end{array}$ \\
\hline$R O A$ & $\begin{array}{c}5.675769 \\
10.588 * * *\end{array}$ & $\begin{array}{l}-0.976894 \\
-2.320 * *\end{array}$ & $\begin{array}{l}1.186278 \\
10.89 * * *\end{array}$ & $\begin{array}{l}-0.590808 \\
-5.14 * * *\end{array}$ \\
\hline BTM & $\begin{array}{c}-0.151029 \\
-1.449\end{array}$ & $\begin{array}{c}0.005820 \\
0.070\end{array}$ & $\begin{array}{c}-0.030066 \\
-1.38\end{array}$ & $\begin{array}{c}0.010673 \\
0.47\end{array}$ \\
\hline \multicolumn{5}{|c|}{ Investing/Reporting } \\
\hline$R D$ & $\begin{array}{l}-7.190267 \\
-9.559 * * *\end{array}$ & $\begin{array}{l}4.282788 \\
7.757 * * *\end{array}$ & $\begin{array}{l}-1.729298 \\
-11.31 * * *\end{array}$ & $\begin{array}{l}1.510307 \\
10.02 * * *\end{array}$ \\
\hline$D I S C \_A C C$ & $\begin{array}{c}0.151220 \\
0.507\end{array}$ & $\begin{array}{l}-0.901739 \\
-3.502 * * *\end{array}$ & $\begin{array}{c}0.096839 \\
1.53\end{array}$ & $\begin{array}{l}-0.234732 \\
-3.36 * * *\end{array}$ \\
\hline Constant & $\begin{array}{c}-0.467221 \\
-0.670\end{array}$ & $\begin{array}{c}-1.082376 \\
-1.484\end{array}$ & & \\
\hline $\begin{array}{l}\text { LR Test of } \\
\text { Independence } \\
\text { Observations }\end{array}$ & $\begin{array}{c}247.93 \\
4,668\end{array}$ & $\begin{array}{c}p<0.01 \\
4,668\end{array}$ & & \\
\hline $\begin{array}{l}* * * p<0.01, * * p< \\
\text { Each regression m } \\
\text { All variables excep } \\
\text { percentiles. } \\
\text { The estimate of the } \\
\text { Columns ( } 3 \text { ) and ( } \\
\text { dependent variable }\end{array}$ & $\begin{array}{l}10 . \\
\text { ted with industry } \\
\text { MINIMIZE, FOR } \\
\text { mong the equati } \\
\text { bivariate margin } \\
\text { (i.e., of the firm }\end{array}$ & $\begin{array}{l}\text { effects (two-digi } \\
T L C F \text {, and } S E G N \\
\text { r terms is }-0.523 \\
\text { ability effects of } \\
\text { ng either a susta }\end{array}$ & $\begin{array}{l}\text { ode). } \\
\text { have been win } \\
\text { gnificant at the } \\
\text { ovariate on the } \\
\text { or minimizatio }\end{array}$ & $\begin{array}{l}\text { at the } 1^{\text {st }} \text { and } 99^{\text {th }} \\
\text { el. } \\
\text { ility of the } \\
\text { ategy). }\end{array}$ \\
\hline
\end{tabular}


TABLE 4

Selection Model - Probability of Purchasing Auditor Provided Tax Services

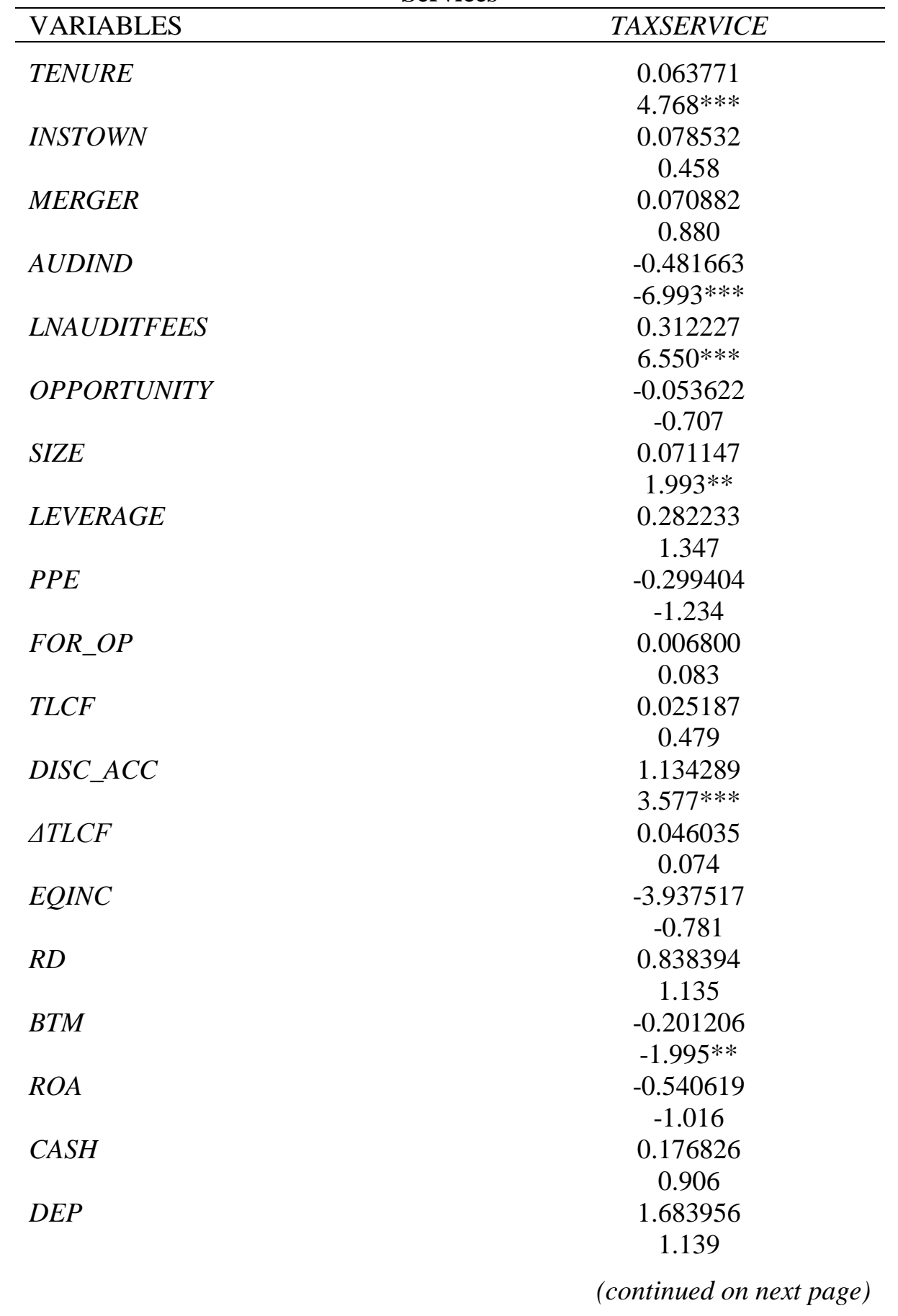


TABLE 4 (continued)

\begin{tabular}{|c|c|}
\hline VARIABLES & TAXSERVICE \\
\hline \multirow[t]{2}{*}{$B I G 4$} & 0.068127 \\
\hline & 0.478 \\
\hline \multirow[t]{2}{*}{ SECTIER } & -0.521715 \\
\hline & $-2.705 * * *$ \\
\hline \multirow[t]{2}{*}{ Constant } & -4.748557 \\
\hline & $-5.821 * * *$ \\
\hline Area under the ROC Curve & 0.827 \\
\hline Observations & 4,668 \\
\hline \multicolumn{2}{|c|}{$\begin{array}{l}* * * *_{p}<0.01, * * *_{p}<0.05,{ }^{*}<0.10 . \\
\text { The logistic regression model is estimated with industry (two-digit SIC code) and year fixed effects. } \\
\text { All variables except TAXSERVICE, TENURE, MERGER, FOR_OP, TLCF, BIG4, and SECTIER have been winsorized } \\
\text { at the } 1^{\text {st }} \text { and } 99^{\text {th }} \text { percentiles. }\end{array}$} \\
\hline
\end{tabular}


TABLE 5

Expert Tax Advice - Seemingly Unrelated Bivariate Probit Regression

\begin{tabular}{|c|c|c|c|c|}
\hline VARIABLES & $\begin{array}{c}(1) \\
\text { SUSTAIN }\end{array}$ & $\begin{array}{c}(2) \\
M I N I M I Z E\end{array}$ & $\begin{array}{c}(3) \\
\text { SUSTAIN }\end{array}$ & $\begin{array}{c}(4) \\
M I N I M I Z E\end{array}$ \\
\hline & & & Marginal Effects & Marginal Effects \\
\hline \multicolumn{5}{|c|}{ Managerial Incentives/Practices } \\
\hline TAXEXPERT & $\begin{array}{c}-0.043345 \\
-0.859\end{array}$ & $\begin{array}{c}0.103329 \\
2.295 * *\end{array}$ & $\begin{array}{c}-0.015067 \\
-1.49\end{array}$ & $\begin{array}{c}0.033290 \\
2.86 * * *\end{array}$ \\
\hline \multicolumn{5}{|l|}{$\underline{\text { Tax Planning }}$} \\
\hline$\overline{S I Z E}$ & $\begin{array}{l}0.131879 \\
6.558 * * *\end{array}$ & $\begin{array}{c}-0.016928 \\
-0.958\end{array}$ & $\begin{array}{c}0.027607 \\
6.69 * * *\end{array}$ & $\begin{array}{c}-0.011001 \\
-2.37 * *\end{array}$ \\
\hline LEVERAGE & $\begin{array}{l}-0.590497 \\
-3.006 * * *\end{array}$ & $\begin{array}{l}0.441209 \\
2.595 * * *\end{array}$ & $\begin{array}{l}-0.149541 \\
-3.57 * * *\end{array}$ & $\begin{array}{c}0.146366 \\
3.16^{* * *}\end{array}$ \\
\hline$P P E$ & $\begin{array}{c}-0.359739 \\
-1.872 *\end{array}$ & $\begin{array}{l}0.641811 \\
3.809 * * *\end{array}$ & $\begin{array}{l}-0.121572 \\
-2.97 * * *\end{array}$ & $\begin{array}{c}0.177861 \\
3.90 * * *\end{array}$ \\
\hline FOR_OP & $\begin{array}{c}-0.064533 \\
-0.950\end{array}$ & $\begin{array}{c}0.131134 \\
2.157 * *\end{array}$ & $\begin{array}{c}-0.023410 \\
-1.69^{*}\end{array}$ & $\begin{array}{c}0.033251 \\
1.99 * *\end{array}$ \\
\hline$T L C F$ & $\begin{array}{l}-0.154694 \\
-3.277 * * *\end{array}$ & $\begin{array}{c}0.091737 \\
2.192 * *\end{array}$ & $\begin{array}{l}-0.036813 \\
-3.74 * * *\end{array}$ & $\begin{array}{c}0.033984 \\
2.91 * * *\end{array}$ \\
\hline SEGMENTS & $\begin{array}{c}-0.000226 \\
-0.021\end{array}$ & $\begin{array}{c}-0.004405 \\
-0.462\end{array}$ & $\begin{array}{c}0.000202 \\
0.09\end{array}$ & $\begin{array}{c}-0.001126 \\
-0.43\end{array}$ \\
\hline \multicolumn{5}{|l|}{ Performance } \\
\hline$C V \_P T B I$ & $\begin{array}{c}-2.524860 \\
-19.487 * * *\end{array}$ & $\begin{array}{l}0.246306 \\
9.167 * * *\end{array}$ & $\begin{array}{l}-0.515703 \\
-24.72 * * *\end{array}$ & $\begin{array}{l}0.216624 \\
19.11 * * *\end{array}$ \\
\hline$R O A$ & $\begin{array}{c}5.681235 \\
10.598 * * *\end{array}$ & $\begin{array}{l}-0.936214 \\
-2.223 * *\end{array}$ & $\begin{array}{l}1.187869 \\
10.88 * * *\end{array}$ & $\begin{array}{l}-0.591618 \\
-5.15^{* * *}\end{array}$ \\
\hline$B T M$ & $\begin{array}{c}-0.168724 \\
-1.629\end{array}$ & $\begin{array}{c}-0.007282 \\
-0.087\end{array}$ & $\begin{array}{c}-0.032713 \\
-1.51\end{array}$ & $\begin{array}{c}0.005846 \\
0.26\end{array}$ \\
\hline \multicolumn{5}{|c|}{ Investing/Reporting } \\
\hline$R D$ & $\begin{array}{l}-7.113835 \\
-9.524 * * *\end{array}$ & $\begin{array}{l}4.517586 \\
8.239 * * *\end{array}$ & $\begin{array}{l}-1.739652 \\
-11.42 * * *\end{array}$ & $\begin{array}{l}1.562638 \\
10.44 * * *\end{array}$ \\
\hline$D I S C \_A C C$ & $\begin{array}{c}0.132604 \\
0.444\end{array}$ & $\begin{array}{l}-0.942961 \\
-3.660 * * *\end{array}$ & $\begin{array}{c}0.095920 \\
1.51\end{array}$ & $\begin{array}{l}-0.239901 \\
-3.43 * * *\end{array}$ \\
\hline$I M R$ & $\begin{array}{c}-0.224824 \\
-0.863\end{array}$ & $\begin{array}{c}-0.325093 \\
-1.434\end{array}$ & & \\
\hline Constant & $\begin{array}{c}-0.370059 \\
-0.515\end{array}$ & $\begin{array}{c}-1.014474 \\
-1.355\end{array}$ & & \\
\hline $\begin{array}{l}\text { LR Test of } \\
\text { Independence } \\
\text { Observations }\end{array}$ & $\begin{array}{c}226.01 \\
4,668\end{array}$ & $\begin{array}{c}p<0.01 \\
4,668\end{array}$ & & \\
\hline \multicolumn{5}{|c|}{$\begin{array}{l}* * * p<0.01, * * p<0.05, * p<0.10 \text {. } \\
\text { Each regression model is estimated with industry fixed effects (two-digit SIC code). } \\
\text { All variables except SUSTAIN, MINIMIZE, TAXEXPERT, FOR_OP, TLCF, SEGMENTS, and IMR have been winsorized } \\
\text { at the } 1^{\text {st }} \text { and } 99^{\text {th }} \text { percentiles. } \\
\text { The estimate of the correlation among the equation error terms is }-0.521 \text { and significant at the } 1 \% \text { level. } \\
\text { Columns (3) and (4) present the bivariate marginal probability effects of each covariate on the probability of the dependent } \\
\text { variable equaling one (i.e., of the firm adopting either a sustainable or minimization tax strategy). These effects are } \\
\text { estimated for the model without the inclusion of IMR because marginal effects cannot be estimated for factor variables. }\end{array}$} \\
\hline
\end{tabular}


TABLE 6

Information Transfer through Directors - Seemingly Unrelated Bivariate Probit Regression

\begin{tabular}{|c|c|c|c|c|}
\hline VARIABLES & $\begin{array}{c}(1) \\
\text { SUSTAIN }\end{array}$ & $\begin{array}{c}(2) \\
M I N I M I Z E\end{array}$ & $\begin{array}{c}(3) \\
\text { SUSTAIN }\end{array}$ & $\begin{array}{c}(4) \\
M I N I M I Z E\end{array}$ \\
\hline & & & $\begin{array}{l}\text { Marginal } \\
\text { Effects }\end{array}$ & $\begin{array}{l}\text { Marginal } \\
\text { Effects }\end{array}$ \\
\hline \multicolumn{5}{|c|}{ Managerial Incentives/Practices } \\
\hline INFO TRANSFER & $\begin{array}{c}-0.071798 \\
-2.535^{* *}\end{array}$ & $\begin{array}{l}0.065220 \\
2.590 * * *\end{array}$ & $\begin{array}{l}-0.018967 \\
-3.12 * * *\end{array}$ & $\begin{array}{l}0.020735 \\
3.02 * * *\end{array}$ \\
\hline \multicolumn{5}{|l|}{ Tax Planning } \\
\hline SIZE & $\begin{array}{l}0.160496 \\
7.376 * * *\end{array}$ & $\begin{array}{c}-0.025554 \\
-1.342\end{array}$ & $\begin{array}{c}0.033414 \\
7.25 * * *\end{array}$ & $\begin{array}{c}-0.016242 \\
-3.14 * * *\end{array}$ \\
\hline LEVERAGE & $\begin{array}{l}-0.564252 \\
-2.869 * * *\end{array}$ & $\begin{array}{c}0.425070 \\
2.502 * *\end{array}$ & $\begin{array}{l}-0.142519 \\
-3.41 * * *\end{array}$ & $\begin{array}{c}0.141053 \\
3.05 * * *\end{array}$ \\
\hline$P P E$ & $\begin{array}{c}-0.349133 \\
-1.836^{*}\end{array}$ & $\begin{array}{l}0.563370 \\
3.369 * * *\end{array}$ & $\begin{array}{l}-0.110627 \\
-2.71 * * *\end{array}$ & $\begin{array}{c}0.162492 \\
3.57 * * *\end{array}$ \\
\hline$F O R \_O P$ & $\begin{array}{c}-0.063737 \\
-0.972\end{array}$ & $\begin{array}{c}0.081308 \\
1.386\end{array}$ & $\begin{array}{c}-0.018450 \\
-1.33\end{array}$ & $\begin{array}{c}0.024582 \\
1.49\end{array}$ \\
\hline$T L C F$ & $\begin{array}{l}-0.156515 \\
-3.344 * * *\end{array}$ & $\begin{array}{l}0.111278 \\
2.672 * * *\end{array}$ & $\begin{array}{l}-0.039097 \\
-3.98 * * *\end{array}$ & $\begin{array}{c}0.037637 \\
3.21 * * *\end{array}$ \\
\hline SEGMENTS & $\begin{array}{c}0.001677 \\
0.155\end{array}$ & $\begin{array}{c}-0.006729 \\
-0.703\end{array}$ & $\begin{array}{c}0.000832 \\
0.36\end{array}$ & $\begin{array}{c}-0.001788 \\
-0.69\end{array}$ \\
\hline \multicolumn{5}{|l|}{ Performance } \\
\hline$C V \_P T B I$ & $\begin{array}{c}-2.543110 \\
-19.576 * * *\end{array}$ & $\begin{array}{l}0.246214 \\
9.188 * * *\end{array}$ & $\begin{array}{l}-0.517596 \\
-24.79 * * *\end{array}$ & $\begin{array}{l}0.217612 \\
19.18 * * *\end{array}$ \\
\hline$R O A$ & $\begin{array}{c}5.597580 \\
10.440 * * *\end{array}$ & $\begin{array}{l}-0.935224 \\
-2.223^{* *}\end{array}$ & $\begin{array}{l}1.168668 \\
10.70 * * *\end{array}$ & $\begin{array}{l}-0.577440 \\
-5.02 * * *\end{array}$ \\
\hline$B T M$ & $\begin{array}{l}-0.212660 \\
-2.031 * *\end{array}$ & $\begin{array}{c}-0.004659 \\
-0.056\end{array}$ & $\begin{array}{c}-0.041396 \\
-1.89 *\end{array}$ & $\begin{array}{c}0.011874 \\
0.52\end{array}$ \\
\hline \multicolumn{5}{|l|}{ Investing/Reporting } \\
\hline$R D$ & $\begin{array}{l}-7.108170 \\
-9.531 * * *\end{array}$ & $\begin{array}{l}4.525143 \\
8.255^{* * *} *\end{array}$ & $\begin{array}{l}-1.733420 \\
-11.41 * * *\end{array}$ & $\begin{array}{l}1.569134 \\
10.48^{* * *} *\end{array}$ \\
\hline$D I S C \_A C C$ & $\begin{array}{c}0.158554 \\
0.531\end{array}$ & $\begin{array}{l}-0.936518 \\
-3.637 * * *\end{array}$ & $\begin{array}{c}0.100873 \\
1.59\end{array}$ & $\begin{array}{l}-0.243905 \\
-3.48 * * *\end{array}$ \\
\hline Constant & $\begin{array}{c}-0.749225 \\
-1.067\end{array}$ & $\begin{array}{c}-1.002369 \\
-1.368\end{array}$ & & \\
\hline $\begin{array}{l}\text { LR Test of } \\
\text { Independence } \\
\text { Observations }\end{array}$ & $\begin{array}{c}247.39 \\
4,668\end{array}$ & $\begin{array}{c}p<0.01 \\
4,668\end{array}$ & & \\
\hline $\begin{array}{l}* * * p<0.01, * * p<0.05 \text {, } \\
\text { Each regression model is } \\
\text { All variables except SUS } \\
99^{\text {th }} \text { percentiles. } \\
\text { The estimate of the corre } \\
\text { Columns (3) and (4) pres } \\
\text { dependent variable equal }\end{array}$ & $\begin{array}{l}0.10 . \\
\text { hated with indust } \\
\text { MINIMIZE, FC } \\
\text { among the equa } \\
\text { he bivariate marg } \\
\text { ne (i.e., of the fir }\end{array}$ & $\begin{array}{l}\text { d effects (two-d } \\
T L C F \text {, and } S E \\
\text { ror terms is }-0.5 \\
\text { obability effects } \\
\text { pting either a su }\end{array}$ & $\begin{array}{l}\text { C code). } \\
\text { TS have been v } \\
\text { significant at } \mathrm{t} \\
\text { le or minimizat }\end{array}$ & $\begin{array}{l}\text { zed at the } 1^{\text {st }} \text { and } \\
\text { level. } \\
\text { bability of the } \\
\text { strategy). }\end{array}$ \\
\hline
\end{tabular}


TABLE 8

Matched Firm Analysis

\begin{tabular}{|c|c|c|c|c|}
\hline VARIABLES & $\begin{array}{c}(1) \\
\text { SUSTAIN } \\
\end{array}$ & $\begin{array}{c}(2) \\
\text { SUSTAIN } \\
\end{array}$ & $\begin{array}{c}(3) \\
\text { SUSTAIN } \\
\end{array}$ & $\begin{array}{c}(4) \\
\text { SUSTAIN } \\
\end{array}$ \\
\hline \multicolumn{5}{|c|}{ Managerial Incentives/Practices } \\
\hline DELTA & $\begin{array}{l}0.000145 \\
3.557 * * *\end{array}$ & & & $\begin{array}{l}0.000137 \\
3.327 * * *\end{array}$ \\
\hline$V E G A$ & $\begin{array}{c}-0.000319 \\
-1.326\end{array}$ & & & $\begin{array}{c}-0.000256 \\
-1.016\end{array}$ \\
\hline TAXEXPERT & & $\begin{array}{c}-0.263668 \\
-2.013 * *\end{array}$ & & $\begin{array}{c}-0.288373 \\
-2.192 * *\end{array}$ \\
\hline INFO TRANSFER & & & $\begin{array}{l}-0.166700 \\
-2.348^{* *}\end{array}$ & $\begin{array}{l}-0.153725 \\
-2.062 * *\end{array}$ \\
\hline \multicolumn{5}{|l|}{ Tax Planning } \\
\hline SIZE & $\begin{array}{c}-0.051347 \\
-0.968\end{array}$ & $\begin{array}{c}0.040522 \\
0.770\end{array}$ & $\begin{array}{c}0.042139 \\
0.747\end{array}$ & $\begin{array}{c}0.062310 \\
1.017\end{array}$ \\
\hline LEVERAGE & $\begin{array}{l}-1.842887 \\
-3.579 * * *\end{array}$ & $\begin{array}{l}-2.199707 \\
-4.273 * * *\end{array}$ & $\begin{array}{l}-2.021507 \\
-3.952 * * *\end{array}$ & $\begin{array}{l}-1.956720 \\
-3.769 * * *\end{array}$ \\
\hline$P P E$ & $\begin{array}{c}-0.850532 \\
-1.716^{*}\end{array}$ & $\begin{array}{c}-1.127290 \\
-2.272 * *\end{array}$ & $\begin{array}{c}-0.765173 \\
-1.551\end{array}$ & $\begin{array}{c}-1.019456 \\
-2.031 * *\end{array}$ \\
\hline$F O R \_O P$ & $\begin{array}{c}-0.217921 \\
-1.306\end{array}$ & $\begin{array}{c}-0.378017 \\
-2.234 * *\end{array}$ & $\begin{array}{c}-0.183183 \\
-1.113\end{array}$ & $\begin{array}{c}-0.357435 \\
-2.079 * *\end{array}$ \\
\hline$T L C F$ & $\begin{array}{c}-0.220042 \\
-1.840^{*}\end{array}$ & $\begin{array}{c}-0.175528 \\
-1.464\end{array}$ & $\begin{array}{c}-0.244288 \\
-2.056^{* *}\end{array}$ & $\begin{array}{c}-0.176008 \\
-1.453\end{array}$ \\
\hline SEGMENTS & $\begin{array}{c}-0.005683 \\
-0.196\end{array}$ & $\begin{array}{c}-0.009122 \\
-0.314\end{array}$ & $\begin{array}{c}-0.003918 \\
-0.135\end{array}$ & $\begin{array}{c}0.000307 \\
0.010\end{array}$ \\
\hline \multicolumn{5}{|l|}{ Performance } \\
\hline$\overline{C V \_P T B I}$ & $\begin{array}{c}-5.298183 \\
-14.941 * * *\end{array}$ & $\begin{array}{c}-5.275233 \\
-15.038 * * *\end{array}$ & $\begin{array}{c}-5.183406 \\
-14.923 * * *\end{array}$ & $\begin{array}{c}-5.483688 \\
-15.120 * * *\end{array}$ \\
\hline$R O A$ & $\begin{array}{c}12.324620 \\
8.037 * * *\end{array}$ & $\begin{array}{c}12.088076 \\
7.889 * * *\end{array}$ & $\begin{array}{c}11.995359 \\
7.886^{* * *}\end{array}$ & $\begin{array}{c}11.992319 \\
7.748 * * *\end{array}$ \\
\hline BTM & $\begin{array}{c}-0.287562 \\
-1.022\end{array}$ & $\begin{array}{c}-0.488319 \\
-1.750 *\end{array}$ & $\begin{array}{c}-0.496883 \\
-1.773^{*}\end{array}$ & $\begin{array}{c}-0.483626 \\
-1.676^{*}\end{array}$ \\
\hline \multicolumn{5}{|l|}{ Investing/Reporting } \\
\hline$R D$ & $\begin{array}{c}-17.759347 \\
-9.585 * * *\end{array}$ & $\begin{array}{c}-17.865106 \\
-9.678^{* * *}\end{array}$ & $\begin{array}{c}-17.456647 \\
-9.480 * * *\end{array}$ & $\begin{array}{c}-17.975716 \\
-9.715 * * *\end{array}$ \\
\hline$D I S C \_A C C$ & $\begin{array}{c}1.019789 \\
1.271\end{array}$ & $\begin{array}{c}0.789634 \\
0.990\end{array}$ & $\begin{array}{c}0.908616 \\
1.141\end{array}$ & $\begin{array}{c}0.962777 \\
1.193\end{array}$ \\
\hline IMR & & $\begin{array}{l}1.906891 \\
2.674 * * *\end{array}$ & & $\begin{array}{l}1.888581 \\
2.615^{* * * *}\end{array}$ \\
\hline Pseudo R-Square & 0.328 & 0.328 & 0.324 & 0.335 \\
\hline Observations & 1,998 & 1,998 & 1,998 & 1,998 \\
\hline \multicolumn{5}{|c|}{$\begin{array}{l}* * * p<0.01, * * p<0.05, * p<0.10 \text {. } \\
\text { Each logistic regression model is estimated with industry fixed effects (two-digit SIC code). } \\
\text { The sample consists of } 999 \text { unique pairs of sustainable and minimization tax strategy firms that have been matched on SIZE } \\
\text { within both industry (Fama French } 17 \text { classification) and year without replacement. } \\
\text { All variables except SUSTAIN, MINIMIZE, FOR_OP, TLCF, SEGMENTS, and IMR have been winsorized at the } 1^{\text {st }} \text { and } \\
99^{\text {th }} \text { percentiles. }\end{array}$} \\
\hline
\end{tabular}


TABLE 9

Firm Value Analysis - Univariate Comparisons Panel A: Market Value of Equity Comparison of SUSTAIN and MIXED Tax Strategies

\begin{tabular}{|c|c|c|c|c|c|c|c|c|c|c|c|c|}
\hline \multirow[b]{2}{*}{ Variable } & \multicolumn{5}{|c|}{ Firm Value - SUSTAIN } & \multicolumn{5}{|c|}{ Firm Value - MIXED } & \multicolumn{2}{|c|}{$\begin{array}{c}\text { Tests of Mean and Median } \\
\text { Differences }\end{array}$} \\
\hline & Mean & $\begin{array}{l}\text { Std } \\
\text { Dev }\end{array}$ & $25 \%$ & Median & $75 \%$ & Mean & $\begin{array}{l}\text { Std } \\
\text { Dev }\end{array}$ & $25 \%$ & Median & $75 \%$ & $\begin{array}{c}\text { Mean } \\
\text { Difference } \\
(t) \\
\end{array}$ & $\begin{array}{c}\text { Median } \\
\text { Difference } \\
\text { (Chi- } \\
\text { Square) } \\
\end{array}$ \\
\hline$M V E$ & 1.677 & 1.060 & 0.909 & 1.413 & 2.164 & 1.272 & 0.952 & 0.634 & 1.004 & 1.610 & $11.37 * * *$ & $135.61 * * *$ \\
\hline$M V E_{t+1}$ & 1.593 & 1.004 & 0.868 & 1.340 & 2.059 & 1.218 & 0.890 & 0.610 & 0.973 & 1.557 & $11.05 * * *$ & $132.44 * * *$ \\
\hline$M V E_{t+2}$ & 1.536 & 0.954 & 0.821 & 1.315 & 1.990 & 1.190 & 0.838 & 0.598 & 0.960 & 1.542 & $10.60 * * *$ & $97.31 * * *$ \\
\hline$M V E_{t+3}$ & 1.515 & 0.922 & 0.836 & 1.295 & 1.960 & 1.206 & 0.851 & 0.610 & 0.971 & 1.556 & $8.81 * * *$ & $84.43 * * *$ \\
\hline \multicolumn{13}{|c|}{ Panel B: Market Value of Equity Comparison of MINIMIZE and MIXED Tax Strategies } \\
\hline & \multicolumn{5}{|c|}{ Firm Value - MINIMIZE } & \multicolumn{5}{|c|}{ Firm Value - MIXED } & \multicolumn{2}{|c|}{$\begin{array}{c}\text { Tests of Mean and Median } \\
\text { Differences }\end{array}$} \\
\hline Variable & Mean & $\begin{array}{l}\text { Std } \\
\text { Dev }\end{array}$ & $25 \%$ & Median & $75 \%$ & Mean & $\begin{array}{l}\text { Std } \\
\text { Dev }\end{array}$ & $25 \%$ & Median & $75 \%$ & $\begin{array}{c}\text { Mean } \\
\text { Difference } \\
(t)\end{array}$ & $\begin{array}{c}\text { Median } \\
\text { Difference } \\
\text { (Chi- } \\
\text { Square) }\end{array}$ \\
\hline MVE & 1.468 & 1.105 & 0.717 & 1.139 & 1.830 & 1.272 & 0.952 & 0.634 & 1.004 & 1.610 & $5.47 * * *$ & $21.41 * * *$ \\
\hline$M V E_{t+1}$ & 1.367 & 0.985 & 0.674 & 1.079 & 1.748 & 1.218 & 0.890 & 0.610 & 0.973 & 1.557 & $4.50 * * *$ & $14.25 * * *$ \\
\hline$M V E_{t+2}$ & 1.320 & 0.961 & 0.632 & 1.047 & 1.677 & 1.190 & 0.838 & 0.598 & 0.960 & 1.542 & $4.00 * * *$ & $6.89 * * *$ \\
\hline$M V E_{t+3}$ & 1.326 & 0.966 & 0.651 & 1.061 & 1.671 & 1.206 & 0.851 & 0.610 & 0.971 & 1.556 & $3.33 * * *$ & $6.55^{* * *}$ \\
\hline
\end{tabular}


TABLE 10

Forward Tax Strategy Analysis - Seemingly Unrelated Bivariate Probit Regression

\begin{tabular}{|c|c|c|c|c|c|c|}
\hline VARIABLES & $\begin{array}{c}\text { (1) } \\
\text { SUSTAIN }_{t+1}\end{array}$ & $\begin{array}{c}(2) \\
\operatorname{MINIMIZE}_{t+1}\end{array}$ & $\begin{array}{c}\text { (3) } \\
\text { SUSTAIN }_{t+2}\end{array}$ & $\begin{array}{c}(4) \\
M I N I M I Z E_{t+2}\end{array}$ & $\begin{array}{c}(5) \\
\text { SUSTAIN }_{t+4}\end{array}$ & $\begin{array}{c}(6) \\
M I N I M I Z E_{t+2}\end{array}$ \\
\hline \multicolumn{7}{|c|}{ Managerial Incentives/Practices } \\
\hline DELTA & $\begin{array}{c}0.000002 \\
0.166\end{array}$ & $\begin{array}{c}0.000005 \\
0.393\end{array}$ & $\begin{array}{l}0.000063 \\
2.810 * * *\end{array}$ & $\begin{array}{c}-0.000005 \\
-0.267\end{array}$ & $\begin{array}{c}0.000032 \\
1.628^{*}\end{array}$ & $\begin{array}{c}-0.000005 \\
-0.257\end{array}$ \\
\hline$V E G A$ & $\begin{array}{l}-0.000224 \\
-2.206 * * *\end{array}$ & $\begin{array}{l}0.000311 \\
3.245^{* * * *}\end{array}$ & $\begin{array}{c}-0.000065 \\
-0.513\end{array}$ & $\begin{array}{l}0.000371 \\
3.100 * * *\end{array}$ & $\begin{array}{c}0.000090 \\
0.756\end{array}$ & $\begin{array}{l}0.000364 \\
3.049 * * *\end{array}$ \\
\hline TAXEXPERT & $\begin{array}{c}-0.048228 \\
-1.003\end{array}$ & $\begin{array}{c}0.082673 \\
1.848 * *\end{array}$ & $\begin{array}{l}-0.198696 \\
-2.808 * * *\end{array}$ & $\begin{array}{c}0.073670 \\
1.124\end{array}$ & $\begin{array}{l}-0.115294 \\
-1.734 * *\end{array}$ & $\begin{array}{c}0.066939 \\
1.022\end{array}$ \\
\hline INFO TRANSFER & $\begin{array}{c}-0.040084 \\
-1.428 *\end{array}$ & $\begin{array}{c}0.032016 \\
1.231\end{array}$ & $\begin{array}{c}-0.016532 \\
-0.438\end{array}$ & $\begin{array}{c}0.014709 \\
0.424\end{array}$ & $\begin{array}{c}0.037472 \\
1.058\end{array}$ & $\begin{array}{c}0.017573 \\
0.507\end{array}$ \\
\hline \multicolumn{7}{|l|}{$\underline{\text { Tax Planning }}$} \\
\hline$\overline{S I Z E}$ & $\begin{array}{l}0.173822 \\
7.833 * * *\end{array}$ & $\begin{array}{c}-0.048780 \\
-2.380^{*} *\end{array}$ & $\begin{array}{l}0.154758 \\
4.765 * * *\end{array}$ & $\begin{array}{c}-0.045467 \\
-1.534\end{array}$ & $\begin{array}{c}0.064994 \\
2.154 * *\end{array}$ & $\begin{array}{c}-0.047471 \\
-1.601\end{array}$ \\
\hline LEVERAGE & $\begin{array}{c}-0.358385 \\
-1.952 *\end{array}$ & $\begin{array}{l}0.770247 \\
4.563 * * *\end{array}$ & $\begin{array}{l}-0.840552 \\
-2.920 * * *\end{array}$ & $\begin{array}{l}1.387439 \\
5.418 * * *\end{array}$ & $\begin{array}{l}-0.992094 \\
-3.674 * * *\end{array}$ & $\begin{array}{l}1.420929 \\
5.570^{* * *}\end{array}$ \\
\hline$P P E$ & $\begin{array}{l}-0.601587 \\
-3.261 * * *\end{array}$ & $\begin{array}{l}0.574184 \\
3.413 * * *\end{array}$ & $\begin{array}{l}-0.791994 \\
-2.936^{* * *}\end{array}$ & $\begin{array}{l}1.218991 \\
4.969 * * *\end{array}$ & $\begin{array}{l}-0.768365 \\
-3.077 * * *\end{array}$ & $\begin{array}{l}1.194569 \\
4.890 * * *\end{array}$ \\
\hline FOR_OP & $\begin{array}{c}-0.079428 \\
-1.190\end{array}$ & $\begin{array}{c}0.067136 \\
1.102\end{array}$ & $\begin{array}{l}-0.180098 \\
-2.169 * *\end{array}$ & $\begin{array}{c}-0.013895 \\
-0.183\end{array}$ & $\begin{array}{c}-0.005530 \\
-0.071\end{array}$ & $\begin{array}{c}-0.007018 \\
-0.093\end{array}$ \\
\hline$T L C F$ & $\begin{array}{c}-0.045357 \\
-1.004\end{array}$ & $\begin{array}{c}0.103721 \\
2.487 * *\end{array}$ & $\begin{array}{l}-0.156667 \\
-2.374 * *\end{array}$ & $\begin{array}{c}0.081377 \\
1.355\end{array}$ & $\begin{array}{l}-0.128125 \\
-2.084 * *\end{array}$ & $\begin{array}{c}0.078969 \\
1.316\end{array}$ \\
\hline SEGMENTS & $\begin{array}{c}-0.011206 \\
-1.094\end{array}$ & $\begin{array}{c}-0.010386 \\
-1.092\end{array}$ & $\begin{array}{c}-0.015932 \\
-1.085\end{array}$ & $\begin{array}{c}0.021936 \\
1.692 *\end{array}$ & $\begin{array}{c}-0.018643 \\
-1.382\end{array}$ & $\begin{array}{c}0.019675 \\
1.517\end{array}$ \\
\hline \multicolumn{7}{|l|}{ Performance } \\
\hline$C V_{-} P T B I$ & $\begin{array}{c}-0.044150 \\
-1.519\end{array}$ & $\begin{array}{l}0.233203 \\
8.756^{* * *} *\end{array}$ & $\begin{array}{c}-1.709615 \\
-11.974 * * *\end{array}$ & $\begin{array}{l}0.173073 \\
4.703 * * *\end{array}$ & $\begin{array}{l}-0.319755 \\
-5.372 * * *\end{array}$ & $\begin{array}{l}0.168786 \\
4.669 * * *\end{array}$ \\
\hline$R O A$ & $\begin{array}{c}5.386372 \\
11.247 * * *\end{array}$ & $\begin{array}{l}-1.452036 \\
-3.482 * * *\end{array}$ & $\begin{array}{l}7.792268 \\
9.858 * * *\end{array}$ & $\begin{array}{l}-2.805425 \\
-4.491 * * *\end{array}$ & $\begin{array}{l}4.065492 \\
5.982 * * *\end{array}$ & $\begin{array}{l}-2.691054 \\
-4.341 * * *\end{array}$ \\
\hline$B T M$ & $\begin{array}{l}-0.623105 \\
-6.025^{* * *}\end{array}$ & $\begin{array}{c}0.130326 \\
1.543\end{array}$ & $\begin{array}{l}-0.605978 \\
-3.741 * * *\end{array}$ & $\begin{array}{c}0.316313 \\
2.539 * *\end{array}$ & $\begin{array}{l}-1.400404 \\
-8.420 * * *\end{array}$ & $\begin{array}{l}0.327692 \\
2.640 * * *\end{array}$ \\
\hline \multicolumn{7}{|l|}{ Investing/Reporting } \\
\hline$R D$ & $\begin{array}{l}-4.977988 \\
-7.605 * * *\end{array}$ & $\begin{array}{l}4.092803 \\
7.464 * * *\end{array}$ & $\begin{array}{l}-8.506942 \\
-8.123 * * *\end{array}$ & $\begin{array}{l}5.243290 \\
6.577 * * *\end{array}$ & $\begin{array}{l}-8.434661 \\
-8.966^{* * * *}\end{array}$ & $\begin{array}{l}5.239593 \\
6.581 * * *\end{array}$ \\
\hline$D I S C \_A C C$ & $\begin{array}{c}0.318981 \\
1.147\end{array}$ & $\begin{array}{l}-0.627849 \\
-2.460 * *\end{array}$ & $\begin{array}{c}0.180065 \\
0.443\end{array}$ & $\begin{array}{c}-0.649183 \\
-1.772 *\end{array}$ & $\begin{array}{l}-0.804319 \\
-2.133 * *\end{array}$ & $\begin{array}{c}-0.630932 \\
-1.733 *\end{array}$ \\
\hline$I M R$ & $\begin{array}{c}-0.146904 \\
-0.597\end{array}$ & $\begin{array}{l}-0.448304 \\
-1.989 * *\end{array}$ & $\begin{array}{c}-0.460625 \\
-1.534\end{array}$ & $\begin{array}{c}0.370471 \\
1.394\end{array}$ & $\begin{array}{l}-0.695999 \\
-2.471 * *\end{array}$ & $\begin{array}{c}0.365001 \\
1.374\end{array}$ \\
\hline Constant & $\begin{array}{c}-6.423079 \\
-0.008\end{array}$ & $\begin{array}{c}-0.701420 \\
-0.925\end{array}$ & $\begin{array}{c}-5.782893 \\
-0.002\end{array}$ & $\begin{array}{c}-6.789121 \\
-0.003\end{array}$ & $\begin{array}{c}-4.788942 \\
-0.002\end{array}$ & $\begin{array}{c}-6.756131 \\
-0.003\end{array}$ \\
\hline $\begin{array}{l}\text { LR Test of } \\
\text { Independence } \\
\text { Observations }\end{array}$ & $\begin{array}{c}223.60 \\
4,663\end{array}$ & $\begin{array}{c}p<0.01 \\
4,663\end{array}$ & $\begin{array}{l}98.29 \\
2,525\end{array}$ & $\begin{array}{c}p<0.01 \\
2,525\end{array}$ & $\begin{array}{c}109.69 \\
2,525\end{array}$ & $\begin{array}{c}p<0.01 \\
2,525\end{array}$ \\
\hline $\begin{array}{l}* * * p<0.01, * * p< \\
\text { Each regression mo } \\
\text { All variables except } \\
99^{\text {th }} \text { percentiles. } \\
\text { The estimate of the } \\
\text { regression models. }\end{array}$ & $\begin{array}{l}5, * p<0.10 . \\
\text { is estimated } \\
\text { JSTAIN, MINI } \\
\text { relation amon }\end{array}$ & $\begin{array}{l}\text { gnificance is re } \\
\text { th industry fixec } \\
I I Z E, F O R \_O P \text {, } \\
\text { the equation err }\end{array}$ & $\begin{array}{l}\text { orted based on } \\
\text { effects (two-di } \\
L C F, S E G M E \\
\text { terms is nega }\end{array}$ & $\begin{array}{l}\text { he-tailed tests. } \\
\text { t SIC code). } \\
T S \text {, and } I M R \text { ha }\end{array}$ & $\begin{array}{l}\text { been winsoriz } \\
\text { at the } 1 \% \text { leve }\end{array}$ & $\begin{array}{l}\text { at the } 1^{\text {st }} \text { and } \\
n \text { each set of }\end{array}$ \\
\hline
\end{tabular}


TABLE 12

Mixed Tax Strategy Analysis - Univariate Comparisons Panel A: Firm Characteristics Comparison of SUSTAIN versus MIXED Tax Strategies

\begin{tabular}{|c|c|c|c|c|c|c|c|c|c|c|c|c|}
\hline \multirow[b]{2}{*}{ Variable } & \multicolumn{5}{|c|}{$\begin{array}{c}\text { Descriptive Statistics by Tax Strategy - } \\
\text { SUSTAIN }\end{array}$} & \multicolumn{5}{|c|}{ Descriptive Statistics by Tax Strategy - MIXED } & \multicolumn{2}{|c|}{$\begin{array}{c}\text { Tests of Mean and Median } \\
\text { Differences }\end{array}$} \\
\hline & Mean & $\begin{array}{l}\text { Std } \\
\text { Dev }\end{array}$ & $25 \%$ & Median & $\mathbf{7 5 \%}$ & Mean & $\begin{array}{l}\text { Std } \\
\text { Dev }\end{array}$ & $25 \%$ & Median & $75 \%$ & $\begin{array}{c}\text { Mean } \\
\text { Difference } \\
(t)\end{array}$ & $\begin{array}{c}\text { Median } \\
\text { Difference } \\
\text { (Chi- } \\
\text { Square) } \\
\end{array}$ \\
\hline \multicolumn{13}{|l|}{ Tax Strategies } \\
\hline CV_CETR & 0.191 & 0.072 & 0.136 & 0.192 & 0.248 & 0.634 & 0.294 & 0.402 & 0.56 & 0.791 & $-57.28 * * *$ & $2600 * * *$ \\
\hline CETR3 & 0.287 & 0.078 & 0.235 & 0.291 & 0.341 & 0.334 & 0.148 & 0.243 & 0.292 & 0.365 & $-11.10 * * *$ & 0.09 \\
\hline \multicolumn{13}{|c|}{ Managerial Incentives/Practices } \\
\hline DELTA & 872.666 & 2066.32 & 74.551 & 210.362 & 660.713 & 488.517 & 1355.51 & 43.813 & 126.24 & 368.389 & $6.26 * * *$ & $56.14 * * *$ \\
\hline VEGA & 124.134 & 262.404 & 0 & 0 & 119.636 & 81.993 & 202.712 & 0 & 0 & 65.729 & $5.10 * * *$ & $4.55^{* *}$ \\
\hline TAXEXPERT & 0.603 & 0.489 & 0 & 1 & 1 & 0.537 & 0.499 & 0 & 1 & 1 & $3.77 * * *$ & 0.03 \\
\hline $\begin{array}{l}\text { INFO } \\
\text { TRANSFER }\end{array}$ & 0.166 & 1.025 & -0.608 & -0.033 & 0.757 & -0.094 & 0.986 & -0.792 & -0.294 & 0.371 & $7.30^{* * *}$ & $39.54 * * *$ \\
\hline \multicolumn{13}{|l|}{ Tax Planning } \\
\hline SIZE & 8.256 & 1.432 & 7.218 & 8.175 & 9.205 & 7.657 & 1.37 & 6.647 & 7.492 & 8.541 & $12.06 * * *$ & $98.04 * * *$ \\
\hline LEVERAGE & 0.166 & 0.129 & 0.056 & 0.158 & 0.25 & 0.173 & 0.14 & 0.041 & 0.16 & 0.265 & -1.44 & 0.05 \\
\hline PPE & 0.255 & 0.179 & 0.129 & 0.21 & 0.339 & 0.254 & 0.191 & 0.109 & 0.205 & 0.347 & 0.24 & 0.23 \\
\hline FOR_OP & 0.138 & 0.345 & 0 & 0 & 0 & 0.126 & 0.332 & 0 & 0 & 0 & 1.03 & 0.95 \\
\hline$T L C \bar{F}$ & 0.407 & 0.491 & 0 & 0 & 1 & 0.481 & 0.5 & 0 & 0 & 1 & $-4.22 * * *$ & $17.44 * * *$ \\
\hline SEGMENTS & 3.649 & 2.333 & 1 & 3 & 5 & 3.631 & 2.531 & 1 & 3 & 5 & 0.21 & $2.70 *$ \\
\hline \multicolumn{13}{|l|}{ Performance } \\
\hline$C V P T B I$ & 0.244 & 0.15 & 0.138 & 0.206 & 0.319 & 0.562 & 0.759 & 0.227 & 0.383 & 0.602 & $-16.08 * * *$ & $388.75 * * *$ \\
\hline$R \overline{O A}$ & 0.093 & 0.054 & 0.058 & 0.089 & 0.122 & 0.059 & 0.061 & 0.028 & 0.055 & 0.088 & $16.80 * * *$ & $269.63 * * *$ \\
\hline BTM & 0.386 & 0.245 & 0.217 & 0.336 & 0.506 & 0.523 & 0.321 & 0.31 & 0.455 & 0.661 & $-13.50 * * *$ & $135.47 * * *$ \\
\hline \multicolumn{13}{|c|}{ Investing/Reporting } \\
\hline$R D$ & 0.019 & 0.032 & 0 & 0.001 & 0.025 & 0.027 & 0.045 & 0 & 0.002 & 0.036 & $-5.83 * * *$ & 0.26 \\
\hline DISC_ACC & 0.055 & 0.089 & 0.002 & 0.044 & 0.104 & 0.051 & 0.095 & -0.007 & 0.046 & 0.111 & 1.13 & 0.09 \\
\hline
\end{tabular}


TABLE 12 (continued)

Panel B: Firm Characteristics Comparison of MINIMIZE versus MIXED Tax Strategies

\begin{tabular}{|c|c|c|c|c|c|c|c|c|c|c|c|c|}
\hline \multirow[b]{2}{*}{ Variable } & \multicolumn{5}{|c|}{$\begin{array}{c}\text { Descriptive Statistics by Tax Strategy - } \\
\text { MINIMIZE }\end{array}$} & \multicolumn{5}{|c|}{ Descriptive Statistics by Tax Strategy - MIXED } & \multicolumn{2}{|c|}{$\begin{array}{c}\text { Tests of Mean and Median } \\
\text { Differences }\end{array}$} \\
\hline & Mean & Std Dev & $25 \%$ & Median & $75 \%$ & Mean & $\begin{array}{l}\text { Std } \\
\text { Dev }\end{array}$ & $25 \%$ & Median & $75 \%$ & $\begin{array}{c}\text { Mean } \\
\text { Difference } \\
(t) \\
\end{array}$ & $\begin{array}{c}\text { Median } \\
\text { Difference } \\
\text { (Chi- } \\
\text { Square) } \\
\end{array}$ \\
\hline \multicolumn{13}{|l|}{ Tax Strategies } \\
\hline$C V_{-} C E T R$ & 0.855 & 0.495 & 0.458 & 0.753 & 1.161 & 0.634 & 0.294 & 0.402 & 0.56 & 0.791 & $15.69 * * *$ & $102.10 * * *$ \\
\hline CETR3 & 0.11 & 0.063 & 0.059 & 0.121 & 0.164 & 0.334 & 0.148 & 0.243 & 0.292 & 0.365 & $-56.70 * * *$ & $3300 * * *$ \\
\hline \multicolumn{13}{|c|}{ Managerial Incentives/Practices } \\
\hline DELTA & 674.545 & 1665.16 & 61.962 & 185.237 & 546.368 & 488.517 & 1355.51 & 43.813 & 126.24 & 368.389 & $3.53 * * *$ & $26.86 * * *$ \\
\hline VEGA & 125.171 & 259.879 & 0 & 0 & 121.258 & 81.993 & 202.712 & 0 & 0 & 65.729 & $5.35 * * *$ & $34.41 * * *$ \\
\hline TAXEXPERT & 0.579 & 0.494 & 0 & 1 & 1 & 0.537 & 0.499 & 0 & 1 & 1 & $2.44 * * *$ & 0.03 \\
\hline $\begin{array}{l}\text { INFO } \\
\text { TRANSFER }\end{array}$ & -0.021 & 0.995 & -0.737 & -0.267 & 0.522 & -0.094 & 0.986 & -0.792 & -0.294 & 0.371 & $2.13 * *$ & 0.91 \\
\hline \multicolumn{13}{|l|}{ Tax Planning } \\
\hline$\overline{S I Z E}$ & 7.599 & 1.463 & 6.6 & 7.468 & 8.483 & 7.657 & 1.37 & 6.647 & 7.492 & 8.541 & -1.18 & 0.13 \\
\hline LEVERAGE & 0.178 & 0.148 & 0.034 & 0.164 & 0.275 & 0.173 & 0.14 & 0.041 & 0.16 & 0.265 & 1.04 & 0.56 \\
\hline$P P E$ & 0.263 & 0.226 & 0.092 & 0.181 & 0.367 & 0.254 & 0.191 & 0.109 & 0.205 & 0.347 & 1.27 & $9.84 * * *$ \\
\hline$F O R \_O P$ & 0.147 & 0.355 & 0 & 0 & 0 & 0.126 & 0.332 & 0 & 0 & 0 & 1.80 & $3.06^{* * *}$ \\
\hline$T L C \bar{F}$ & 0.522 & 0.5 & 0 & 1 & 1 & 0.481 & 0.5 & 0 & 0 & 1 & $2.34 * *$ & 0.02 \\
\hline SEGMENTS & 3.438 & 2.337 & 1 & 3 & 5 & 3.631 & 2.531 & 1 & 3 & 5 & $-2.29 * *$ & 0.60 \\
\hline \multicolumn{13}{|l|}{ Performance } \\
\hline$C V_{-} P T B I$ & 0.819 & 1.222 & 0.24 & 0.428 & 0.781 & 0.562 & 0.759 & 0.227 & 0.383 & 0.602 & $7.29 * * *$ & $15.48 * * *$ \\
\hline$R \overline{O A}$ & 0.065 & 0.062 & 0.031 & 0.058 & 0.093 & 0.059 & 0.061 & 0.028 & 0.055 & 0.088 & $2.90 * * *$ & 2.49 \\
\hline BTM & 0.467 & 0.302 & 0.252 & 0.405 & 0.609 & 0.523 & 0.321 & 0.31 & 0.455 & 0.661 & $-5.21 * * *$ & $15.75 * * *$ \\
\hline \multicolumn{13}{|c|}{ Investing/Reporting } \\
\hline$R D$ & 0.044 & 0.056 & 0 & 0.019 & 0.074 & 0.027 & 0.045 & 0 & 0.002 & 0.036 & $9.41 * * *$ & $62.19 * * *$ \\
\hline DISC_ACC & 0.054 & 0.095 & 0.001 & 0.045 & 0.108 & 0.051 & 0.095 & -0.007 & 0.046 & 0.111 & 0.72 & 0.01 \\
\hline
\end{tabular}


TABLE 13

Mixed Tax Strategy Analysis - Multivariate Analysis

\begin{tabular}{|c|c|c|c|c|}
\hline VARIABLES & $\begin{array}{c}(1) \\
\text { MIXED }\end{array}$ & $\begin{array}{c}(2) \\
\text { MINIMIZE }\end{array}$ & $\begin{array}{c}\text { (3) } \\
\text { SUSTAIN }\end{array}$ & $\begin{array}{c}(4) \\
\text { MIXED }\end{array}$ \\
\hline \multicolumn{5}{|c|}{ Managerial Incentives/Practices } \\
\hline DELTA & $\begin{array}{l}-0.000073 \\
-2.532 * *\end{array}$ & $\begin{array}{c}-0.000037 \\
-1.342\end{array}$ & $\begin{array}{c}0.000037 \\
1.342\end{array}$ & $\begin{array}{c}-0.000036 \\
-1.301\end{array}$ \\
\hline$V E G A$ & $\begin{array}{c}0.000093 \\
0.431\end{array}$ & $\begin{array}{l}0.000635 \\
3.213 * * *\end{array}$ & $\begin{array}{l}-0.000635 \\
-3.213 * * *\end{array}$ & $\begin{array}{l}-0.000543 \\
-2.802 * * *\end{array}$ \\
\hline TAXEXPERT & $\begin{array}{c}0.048678 \\
0.502\end{array}$ & $\begin{array}{l}0.276765 \\
2.742 * * *\end{array}$ & $\begin{array}{l}-0.276765 \\
-2.742 * * *\end{array}$ & $\begin{array}{l}-0.228088 \\
-2.760 * * *\end{array}$ \\
\hline INFO TRANSFER & $\begin{array}{c}0.012978 \\
0.227\end{array}$ & $\begin{array}{c}0.116267 \\
2.004 * *\end{array}$ & $\begin{array}{c}-0.116267 \\
-2.004 * *\end{array}$ & $\begin{array}{c}-0.103289 \\
-2.118^{* *}\end{array}$ \\
\hline \multicolumn{5}{|l|}{ Tax Planning } \\
\hline$\overline{S I Z E}$ & $\begin{array}{l}-0.139765 \\
-3.162 * * *\end{array}$ & $\begin{array}{l}-0.165138 \\
-3.601 * * *\end{array}$ & $\begin{array}{l}0.165138 \\
3.601 * * *\end{array}$ & $\begin{array}{c}0.025373 \\
0.662\end{array}$ \\
\hline LEVERAGE & $\begin{array}{c}0.321611 \\
0.849\end{array}$ & $\begin{array}{l}1.158893 \\
2.976 * * *\end{array}$ & $\begin{array}{l}-1.158893 \\
-2.976^{* * *}\end{array}$ & $\begin{array}{l}-0.837282 \\
-2.676 * * *\end{array}$ \\
\hline$P P E$ & $\begin{array}{l}1.260662 \\
3.396 * * *\end{array}$ & $\begin{array}{l}1.953375 \\
5.096 * * *\end{array}$ & $\begin{array}{l}-1.953375 \\
-5.096 * * *\end{array}$ & $\begin{array}{l}-0.692712 \\
-2.221 * *\end{array}$ \\
\hline$F O R \_O P$ & $\begin{array}{c}0.002025 \\
0.015\end{array}$ & $\begin{array}{c}0.215656 \\
1.618\end{array}$ & $\begin{array}{c}-0.215656 \\
-1.618\end{array}$ & $\begin{array}{c}-0.213631 \\
-1.875^{*}\end{array}$ \\
\hline$T L C F$ & $\begin{array}{l}0.221435 \\
2.421 * *\end{array}$ & $\begin{array}{l}0.304746 \\
3.237 * * *\end{array}$ & $\begin{array}{l}-0.304746 \\
-3.237 * * *\end{array}$ & $\begin{array}{c}-0.083310 \\
-1.082\end{array}$ \\
\hline SEGMENTS & $\begin{array}{c}0.042813 \\
2.053 * *\end{array}$ & $\begin{array}{c}0.013179 \\
0.604\end{array}$ & $\begin{array}{c}-0.013179 \\
-0.604\end{array}$ & $\begin{array}{c}0.029634 \\
1.694 *\end{array}$ \\
\hline \multicolumn{5}{|l|}{ Performance } \\
\hline$\overline{C V \_P T B I}$ & $\begin{array}{c}4.533429 \\
17.974 * * *\end{array}$ & $\begin{array}{c}4.790853 \\
18.938 * * *\end{array}$ & $\begin{array}{c}-4.790853 \\
-18.938 * * *\end{array}$ & $\begin{array}{l}-0.257424 \\
-5.498 * * *\end{array}$ \\
\hline$R O A$ & $\begin{array}{l}-12.026693 \\
-11.008 * * *\end{array}$ & $\begin{array}{l}-9.948474 \\
-9.005 * * *\end{array}$ & $\begin{array}{l}9.948474 \\
9.005 * * *\end{array}$ & $\begin{array}{l}-2.078219 \\
-2.700 * * *\end{array}$ \\
\hline BTM & $\begin{array}{c}0.286963 \\
1.427\end{array}$ & $\begin{array}{c}0.174475 \\
0.820\end{array}$ & $\begin{array}{c}-0.174475 \\
-0.820\end{array}$ & $\begin{array}{l}0.112488 \\
0.745\end{array}$ \\
\hline \multicolumn{5}{|l|}{ Investing/Reporting } \\
\hline$R D$ & $\begin{array}{l}14.365133 \\
8.707 * * *\end{array}$ & $\begin{array}{l}17.908583 \\
11.060^{* * *}\end{array}$ & $\begin{array}{l}-17.908583 \\
-11.060 * * *\end{array}$ & $\begin{array}{l}-3.543450 \\
-3.589 * * *\end{array}$ \\
\hline$D I S C \_A C C$ & $\begin{array}{c}0.776947 \\
1.339\end{array}$ & $\begin{array}{l}-1.259526 \\
-2.087 * *\end{array}$ & $\begin{array}{l}1.259526 \\
2.087 * *\end{array}$ & $\begin{array}{l}2.036473 \\
4.360 * * *\end{array}$ \\
\hline$I M R$ & $\begin{array}{c}0.141525 \\
0.292\end{array}$ & $\begin{array}{c}-0.729770 \\
-1.406\end{array}$ & $\begin{array}{c}0.729770 \\
1.406\end{array}$ & $\begin{array}{c}0.871295 \\
2.114 * *\end{array}$ \\
\hline Constant & $\begin{array}{c}-0.297946 \\
-0.217\end{array}$ & $\begin{array}{c}-1.225981 \\
-0.752\end{array}$ & $\begin{array}{c}1.225981 \\
0.752\end{array}$ & $\begin{array}{c}0.928035 \\
0.701\end{array}$ \\
\hline $\begin{array}{l}\text { Pseudo R-Square } \\
\text { Observations }\end{array}$ & $\begin{array}{l}0.197 \\
4,663\end{array}$ & 4,663 & $\begin{array}{l}0.197 \\
4,663\end{array}$ & 4,663 \\
\hline \multicolumn{5}{|c|}{$\begin{array}{l}* * * p<0.01, * * p<0.05, * p<0.10 \text {. } \\
\text { Each multinomial logistic regression model is estimated with industry fixed effects (two-digit SIC code). } \\
\text { All variables except SUSTAIN, MINIMIZE, FOR_OP, TLCF, SEGMENTS, and IMR have been winsorized at the } 1^{\text {st }} \\
\text { and } 99^{\text {th }} \text { percentiles. } \\
\text { The base group for comparison in the analysis in columns (1) and (2) is SUSTAIN; the base group for comparison in } \\
\text { the analysis in columns (3) and (4) is MINIMIZE. }\end{array}$} \\
\hline
\end{tabular}


TABLE 14

Both Tax Strategy Analysis - Univariate Comparisons

\begin{tabular}{|c|c|c|c|c|c|c|c|c|c|c|c|c|}
\hline \multirow[b]{2}{*}{ Variable } & \multicolumn{5}{|c|}{$\begin{array}{c}\text { Descriptive Statistics by Tax Strategy - } \\
\text { SUSTAIN }\end{array}$} & \multicolumn{5}{|c|}{$\begin{array}{l}\text { Descriptive Statistics by Tax Strategy - } \\
\text { BOTH }\end{array}$} & \multicolumn{2}{|c|}{$\begin{array}{l}\text { Tests of Mean and Median } \\
\text { Differences }\end{array}$} \\
\hline & Mean & $\begin{array}{l}\text { Std } \\
\text { Dev }\end{array}$ & $25 \%$ & Median & $75 \%$ & Mean & $\begin{array}{l}\text { Std } \\
\text { Dev }\end{array}$ & $25 \%$ & Median & $75 \%$ & $\begin{array}{c}\text { Mean } \\
\text { Difference } \\
(t)\end{array}$ & $\begin{array}{c}\text { Median } \\
\text { Difference } \\
\text { (Chi- } \\
\text { Square) } \\
\end{array}$ \\
\hline \multicolumn{13}{|l|}{ Tax Strategies } \\
\hline$\overline{C V \_C E T R}$ & 0.191 & 0.072 & 0.136 & 0.192 & 0.248 & 0.237 & 0.061 & 0.198 & 0.246 & 0.283 & $-9.71 * * *$ & $p<0.01$ \\
\hline CETR3 & 0.287 & 0.078 & 0.235 & 0.291 & 0.341 & 0.152 & 0.041 & 0.131 & 0.162 & 0.185 & $32.84 * * *$ & $p<0.01$ \\
\hline \multicolumn{13}{|c|}{ Managerial Incentives/Practices } \\
\hline DELTA & 872.67 & 2066.32 & 74.55 & 210.36 & 660.71 & 1122.16 & 2334.40 & 118.733 & 341.780 & 1109.83 & $-1.76^{*}$ & $p=0.02$ \\
\hline VEGA & 124.13 & 262.40 & 0 & 0 & 119.64 & 201.480 & 358.473 & 0 & 0 & 216.980 & $-4.33 * * *$ & $p=0.24$ \\
\hline TAXEXPERT & 0.603 & 0.489 & 0 & 1 & 1 & 0.668 & 0.472 & 0 & 1 & 1 & $-1.96 * *$ & $p=0.92$ \\
\hline $\begin{array}{l}\text { INFO } \\
\text { TRANSFER }\end{array}$ & 0.166 & 1.025 & -0.608 & -0.033 & 0.757 & 0.331 & 1.125 & -0.568 & 0.063 & 1.034 & $-2.36 * *$ & $p=0.27$ \\
\hline \multicolumn{13}{|l|}{ Tax Planning } \\
\hline SIZE & 8.256 & 1.432 & 7.218 & 8.175 & 9.205 & 8.552 & 1.447 & 7.456 & 8.452 & 9.438 & $-3.03 * * *$ & $p=0.06$ \\
\hline LEVERAGE & 0.166 & 0.129 & 0.056 & 0.158 & 0.25 & 0.168 & 0.110 & 0.088 & 0.168 & 0.251 & -0.25 & $p=0.44$ \\
\hline$P P E$ & 0.255 & 0.179 & 0.129 & 0.21 & 0.339 & 0.269 & 0.214 & 0.128 & 0.186 & 0.342 & -1.11 & $p=0.01$ \\
\hline FOR_OP & 0.138 & 0.345 & 0 & 0 & 0 & 0.166 & 0.373 & 0 & 0 & 0 & -1.16 & $p=0.29$ \\
\hline$T L C \bar{F}$ & 0.407 & 0.491 & 0 & 0 & 1 & 0.465 & 0.500 & 0 & 0 & 1 & $-1.73 *$ & $p=0.10$ \\
\hline SEGMENTS & 3.649 & 2.333 & 1 & 3 & 5 & 4.294 & 2.455 & 3 & 4 & 6 & $-4.06 * * *$ & $p<0.01$ \\
\hline \multicolumn{13}{|l|}{ Performance } \\
\hline$\overline{C V \_P T B I}$ & 0.244 & 0.15 & 0.138 & 0.206 & 0.319 & 0.245 & 0.149 & 0.143 & 0.199 & 0.310 & -0.10 & $p=0.76$ \\
\hline$R \overline{O A}$ & 0.093 & 0.054 & 0.058 & 0.089 & 0.122 & 0.087 & 0.046 & 0.054 & 0.084 & 0.114 & 1.51 & $p=0.76$ \\
\hline BTM & 0.386 & 0.245 & 0.217 & 0.336 & 0.506 & 0.360 & 0.227 & 0.212 & 0.278 & 0.453 & 1.55 & $p=0.02$ \\
\hline \multicolumn{13}{|c|}{ Investing/Reporting } \\
\hline$R D$ & 0.019 & 0.032 & 0 & 0.001 & 0.025 & 0.038 & 0.042 & 0.004 & 0.024 & 0.057 & $-8.98 * * *$ & $p<0.01$ \\
\hline$D I S C \_A C C$ & 0.055 & 0.089 & 0.002 & 0.044 & 0.104 & 0.078 & 0.086 & 0.022 & 0.072 & 0.124 & $-3.83 * * *$ & $p<0.01$ \\
\hline
\end{tabular}


TABLE 14 (continued)

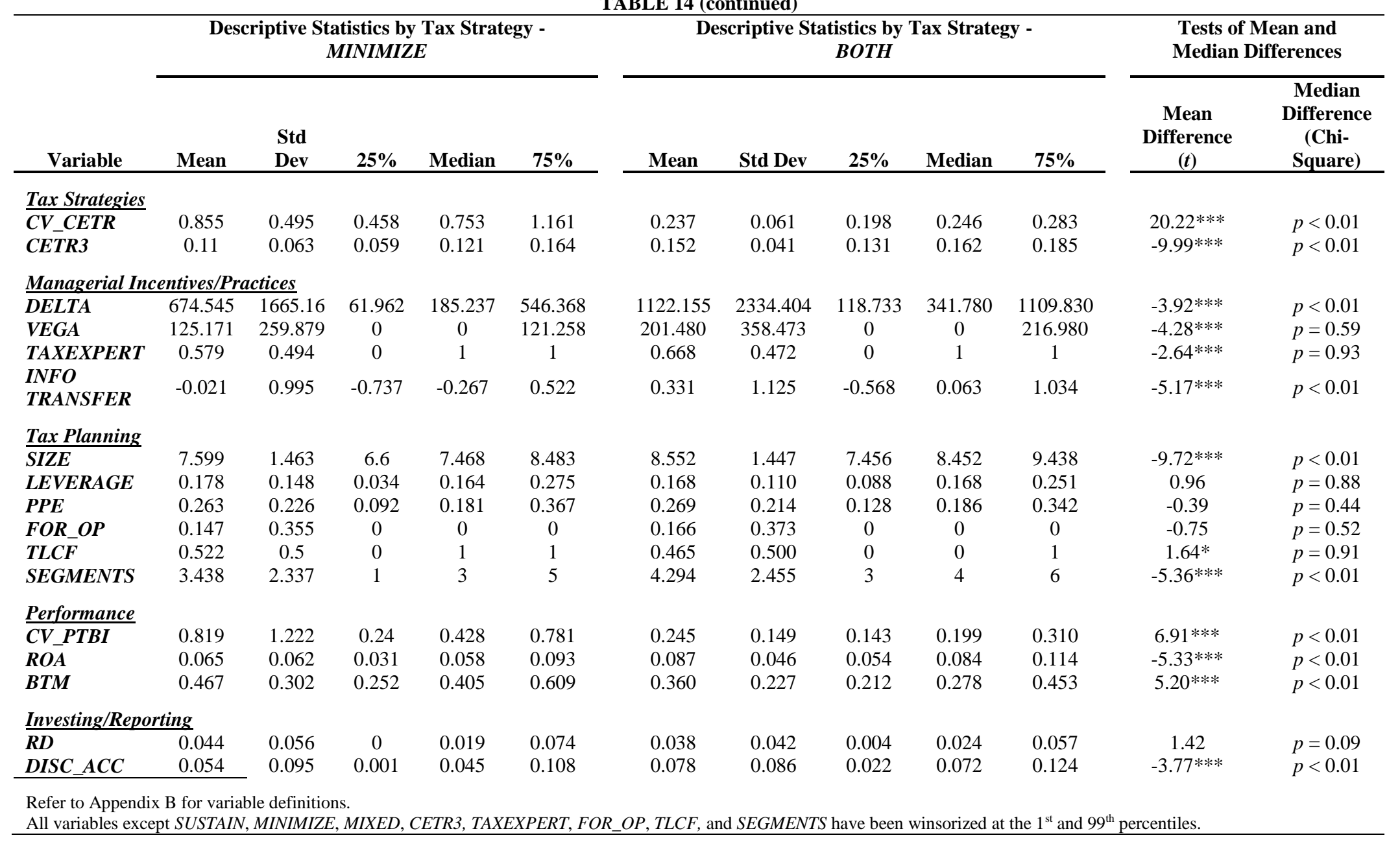

